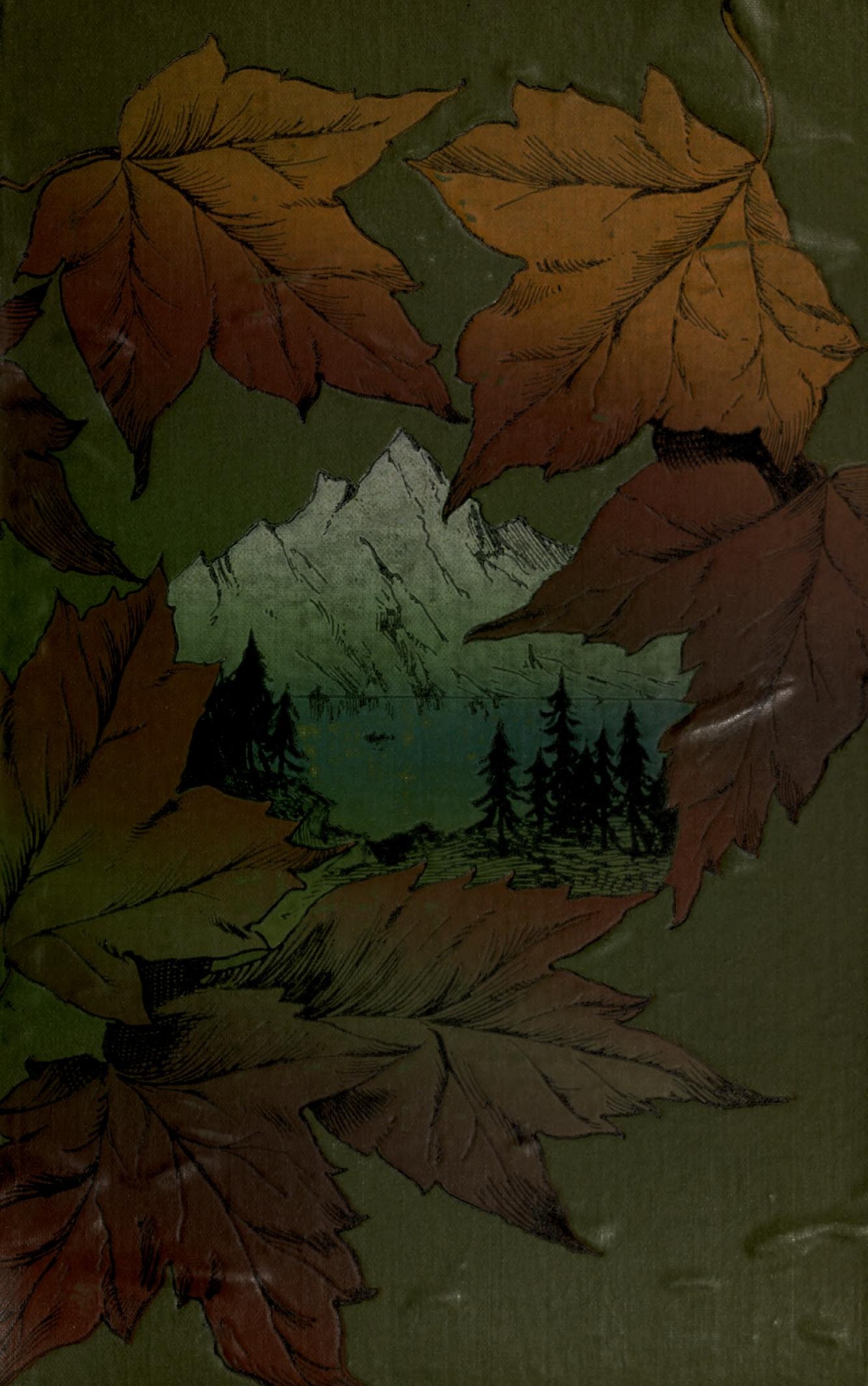


Hogger

Toronto University Library

Resented by

Mess' R. Bentley + Son through the Committee formed in

The Old Country

to aid in replacing the lows caused by The disastrous Tire of February the 14 th 1890 


A SPORTSMAN'S EDEN. 



\section{A SPORTSMAN'S EDEN.}

BY

CLIVE PHILLIPPS-WOLLEY, F.R.G.S.,

Late British Vice-Consul at Kertch,

AUTHOR OF 'SPORT IN THE CRIMEA AND CAUCASUS,' 'SAVAGE SVÂNETIA,' ETé.

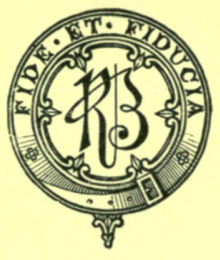

L O N O N :

R I CH A R D B N T L E Y A D S O N,

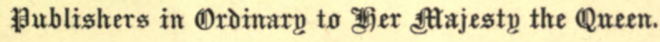
1888. 


$$
833390109^{\circ}
$$




\section{CONTENTS.}

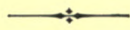

\section{LETTER I.}

A Montreal hotel-The journey out-Sea-sickness-The St. Lawrence-Montreal in winter-A queer dentist-Base-ball

\section{LETTER II.}

Plattsburg-Hotel life-Lakes George and Champlain-A thousand islands-Fort William Henry hotel-A lake-side walk-The scenery - Fishing-Glen Falls_The races Shamus O'Brien-Luggage charges - Saratoga-A night walk

\section{LETTER III.}

Lawn-tennis-Ottawa, or 'Lumber-town'-The Parliament Buildings-Ottawa gay, and sleeping-Pioneer life-Scenes from the Pullman-Nipissing-Through Trapper LandOjibbeway redskins-The forests-An 'improver !'-Cartier to Heron Bay-Angling-Winnipeg lands-SaskatchewanClimbing the Rockies-Across the Selkirks-A returning emigrant-Women's rights-'Through still waters'-Victoria -

\section{LETTER IV.}

Princetown-Sport-Vancouver-AtHope-A Siwash postman - Hope society-Outfit-Estimates-'Along the track'Fly-fishing-Hope Mountains-Grouse-Face to face with a grizzly - A sensational predicament-A victory-Local game stories - 


\section{LETTER V.}

Pack-train travelling-Incomparable foliage-An adventure-

Camping in the dark- $\mathrm{A}$ bad half-hour-Tracking truantsSimilkameen - Ranching - Packing trade - Mule-trains'Washing for gold '-A policeman's career-A pioneer's home -Indian bear-stories-A capital drive-Nine-mile CreekWant of cultivation-Potato patches and graveyards-A cactus joke-Another camp - $\quad$ - $\quad$ - $\quad$ - $\quad$ -

\section{LETTER VI.}

Camp of the winds-Little Tommy-'Caching' luggage-A derelict brandy-bottle-Sporting irregularities - Four bighorn-A climb-Cold and snow-A miserable night-A whisky stimulant-A bad Indian-Our servants' dignities -

\section{LETTER VII.}

Following deer-Views from camp-A deceptive rifle-Toma's first English-Mountain rams-Another miss-fire-Taking to a Winchester - 'Pumping in lead'-A rest _ - -

\section{LETTER VIII.}

A stranger making ' parritch'-Jack rabbits and 'fool hens'Dinner at Bighorn Camp-Impudent robber-birds-A newcomer-Naval whisky-A band of wolves-A lost opportunity

\section{LETTER IX.}

In search of sheep-A broken-winded horse-GrallochingThe wolverine-Rattling of rifles-The first ram-A threemile race-The rejoicing afterwards - $\quad$ - $\quad$ - 104

\section{LETTER X.}

The Dead Forest-A surprise-Full of mule-deer-A big buck -A lynx-trap-Freezing weather-A break-neck canterAnother good day-Deer-fat-Unsought shots-An appeal for mercy-A scalp-lock or a wig ? _ _ _ _ _ - 111 


\section{LETTER XI.}

Waves of purple peaks-Toma's hesitation-A basket of trout -On a bad road-The lazy savage-Dragging the horses uphill-The bleakest camp-A strange find-Great white sterns -Toma's hot pursuit_-'Rams fighting'-A large bighornA night of fête-Two lost beasts-A day's snow-All whiteness-Toma's precautions-More rams-Snow-draped forests

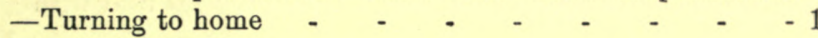

\section{LETTER XII.}

The moose and the white sheep-An Indian 'sweat-horse'The character of the Indians-Plentiful goats-Toma's exertions-Sighting a goat-The 'man-sheep'-A dead goat bleating-An omen-The Indian terrified and tired

\section{LETTER XIII.}

A scare-Ravages of bears-The boat for Westminster-A frozen bath at 4 a.m.-A horse-owner's career-The scorn of beggary-Good-bye to old Mr. S.-Large breeds of cattleTempting rise of trout-A little wading-Sinking in a quicksand-A rueful spectacle-A river fight in difficulties-Brilliant trout-Fourteen Mile House-Free whisky-Riding through darkness and rain-A fagged-out mare-A dead stop-In the lurch-A welcome recovery-Arrival in shelter -

\section{LETTER XIV.}

Wild beasts and wild men-Princetown-Old QuilltasketLaw in British Columbia-Indifferent Christians-Polygamy -Getting whisky-Traits of civilization-How the Indians live-A seventh husband-Opinion about the ladies-The women hardly known from the men - $\quad-\quad-\quad-\quad-152$

\section{LETTER XV.}

Indian fairy-tales-In cow-market-About Tumisco-His adventures-The story of Kee-Kee-Was-The story of Sourgrub-Scuse, from Loo-loo-hoo-loo-Smothering invalids-Funeral feasts-A child's ' wake'-Waste of goods-The fear of ghosts-Paying debts of the deceased - - - - $\quad-158$ 


\section{LETTER XVI.}

Farewell, Sharnus-Perusing a guide-book-Amusing illustrations-From Saratoga to the Blue Mountains-On the coach -A change in the programme-Entered for 'hounding'The necessaries-Posted out-Interesting work-The plan of operations-How the hounds behave-An Ayrshire reminiscence-Lee Harris the angler-Daubing his boat with molasses-The Adirondacks_Want of close-times - $\quad-17$

\section{LETTER XVII.}

Life in Victoria-The Celestials-Fashions and amusementsInvitations-Description of the town-A naval officer's experience with a panther-Looking for a house-A boating picnic-Salmon-fishing-Game-finding in the forest-The atmosphere of Victoria

\section{LETTER XVIII.}

On the Canadian Pacific-A conductor's warning-An Irish omnibus-driver-Rumours of moose-The first time without sun-'No-matter-where'-A Canadian Whiteley's-A courtly manager-Plenty of credit-No bad debts-Arrival of Jocko - A cart expedition-Jocko's life-Lumberers-Small farms -Dense woods-A French Canadian trapper-Darkness and the camp-A last look into the forest-Going moose-hunting -A miracle of beauty-Blondin-like exertions-Jocko's perseverance-Disappointment-Seven miles from camp-A tiring day-Alarmed by wolves-'No-matter-where' better than Brighton

\section{LETTER XIX.}

Story of two moose-heads-How they were obtained-Plenty of snow-White-tail tracks-On the scent of a bull mooseAn ideal scene-Lean meat and hunting-The value of fat - Rewarded at last-One of Nature's first-born-A second day's wanderings-A fusillade-Dead beat-Two bulls brought low-Moose-hunting for legislators-One more day -A major's amusing story - $\quad$ - $\quad$ - $\quad$ - $\quad$ - 21 


\section{LETTER XX.}

Resumé of game laws-These laws criticised-Plea for cooperative legislation-The buffalo-His exterminationTable of close-times for game-Ditto for fish and fur-bearing beasts-Pheasants-The traffic in trophies_-Old methods of destruction-Explanation of the tables-Proposal for national park-Amendments in game laws-Leave-taking - _ _ _ 231

\section{POSTSCRIPT.}

Canadian and London air-A contrast-The professions in the colony-Emigration-Ready employment for good labourWork and wages-Female labour in great demand-Chinese cooks-Cost of food-Interesting facts-Conclusion - $\quad-248$ 



\section{INTRODUCTION.}

Dear Reader,

12, King's Bench Walk.

I am advised that you will require an explanation of the form in which these reminiscences of an autumn, in Canada are offered to you. I have before written in the ordinary form, one chapter following another in the order in which the incidents chronicled in each chapter occurred, and all written by the same hand. Now if I were a Chinaman, writing for possible Chinese emigrants, this would be all as it should be. A Chinese emigration is always, I believe, an emigration of bachelors. They never take their better halves with them. Englishmen rarely leave those better halves behind. A Chinaman goes to sojourn for a few years, devoured all the time by a yearning for the ancestral graveyard, and 
determined at all costs, dead or alive, to return to China. An Englishman not only takes his wife with him when he emigrates, but generally goes to stay. This being so, I felt it my duty to write for both sexes, and as I have very little knowledge of what ladies like, I took my wife with me, and have incorporated her letters to a girl-friend in the same book with letters of mine to a brother limb of the law in England.

There may be, I hope, a few letters from others of our party, who separated from us at one point or another in our journey across America. If they keep their promises and write, I shall give you the benefit of their experiences, warning you that in all cases, though I am responsible for all literary sins within these covers, the writer of each letter is responsible for the opinions therein expressed.

It was at the end of the last London season that our little party got together and booked for Montreal by the Dominion Line. The tennislawns of Montgomeryshire had grown brown and dry, and drier and more parched were the bodies and brains of the husbands and brothers in London, to whom certain Montgomeryshire ladies suggested an autumn in Canada.

The papers had been full of rumours of the great new line which Russia is threatening to 
build across Siberia to the Pacific; of reports of the great new line which the British have built across their Siberia from Montreal to Vancouver.

It is an interesting race, this race of the Teuton and the Slav for the Pacific, and we all wanted to see as much of our share of the course as possible before all this new North-West of ours shall have become trite and commonplace as a London suburb. We knew that the same causes had been at work driving each of these great colonizing nations forward to the same great peaceful ocean; that religious persecution had driven the English to New England, the Russian to the Caucasus and Siberia; gold had enticed the Russian to the Ourals, gold had attracted the Briton to British Columbia; that the Hudson Bay trappers had followed beaver and marten ever further and further west, while his Cossack rival had followed the fur-bearing beast ever further and further to the east; we had grown interested in this march of rival nations towards a common goal, led as they are by descendants from the same old sea-king stock, whether through Rurik, or our William the Conqueror; and, stirred possibly by some tiny leaven of the old wandering blood, which is every Englishman's inheritance, we gave ready ear to the persuasions of our fair friends, and 
were so amply rewarded, that I dare to hope even these poor sketches of our wanderings may be interesting to those who have not yet had time to look at England's great North-West for themselves, or to take toll of the big game of Canada before it has all been driven out and replaced by 'bleating idiotic sheep' and lowing herds.

I have added to the story of our wanderings a few words (or my wife has for me) about British Columbia as a land to live in, for I hear, on trustworthy authority, that there are more English gentlemen (retired soldiers and others) asking for information about our most western towns in America this year than ever before, and almost every number of the Field which I take up contains some inquiry with regard to British Columbia. Whether Vancouver, the town, or Victoria, the capital of Vancouver Island, becomes the nucleus of the English population on our Pacific coast, it seems to me that the degree of England's influence on the Pacific depends a great deal upon the class of emigrants we send out there now, and if there is added to the great mass of English muscle and energy which the mines must attract in the next few years a proportion of the more polished elements of English society, I venture to think 
it will be well for British Columbia, well for the emigrants, and well for England.

Others have written carefully of Canada, town by town; of her great line (the Canadian Pacific Railway), step by step; I only offer you a coup d'œil of the country as a whole, as you might see it if you could spare time yourself to flit through it this autumn. If you like the sketch I give you, take my advice; go and see the original for yourself.

$$
\text { C. P. W. }
$$





\section{A SPORTSMAN'S EDEN.}

\section{LETTER I.}

Typical Hotel, Montreal, Sept. 6, 1887.

Dear Lena,

At last $I$ have a few minutes in which to rest and write to you. The long dinner with its many courses of quaintly-named dishes is over, and the men of our party have gone off, they say, to smoke; but I shrewdly. suspect their search is rather for those stimulants which the Yankees deny them at dinner, than for the innocent cigarette.

This should be the cosiest hour of the day, but here nothing is cosy; it is all too big and bare and brassy. How can one settle down in a tea-gown and slippers in a room with only big furniture in it (no knick-knacks), bare walls, no fire, and not even a fireplace? The whole hotel 
is, to my mind, something between a palace and a prison, gorgeous as the one and stiff and chilling as the other. It seems impossible to give the rooms that air of comfort peculiarly dear to a woman's heart; but in sober truth there is nothing feminine about them. Why, if I ring for a chambermaid, I am answered by a bellboy. An American hotel may be the ideal hotel of business men, who love places studded with electric knobs and hung with telephones, but it is not suited to the cat-like comfort-loving nature of our sex.

You guessed, I suppose, from my recent silence that I had won the day with 'ce cher mari' of mine, and persuaded him to take me with him on his wild-goose chase to America. By the way, I fancy there is a letter wrong there; the animal we are to pursue spells its name with an ' $\mathrm{m}$ ' and not with a ' $\mathrm{g}$ ', and Lena dear, 'we' are to pursue it; you, perhaps, don't take in all that this means at first, but you will by-and-by. It means that $I$ am to follow this monster of mine through pine-forests and snowy wastes, cook his food and clean his rifle, and, as he says, ' make myself generally useful,' instead of fooling the dollars away in the towns. At first, of course, I felt inclined to resist. Even in politics they always have an opposition, and married life 
requires more to enliven it than even politics. Eventually we agreed to a peace with honour, of which the terms were, for me, a visit to all the chief towns of Canada, including Victoria, in British Columbia, and a week on Lakes George and Champlain, America's great holiday resorts, and a peep at Saratoga. After that I agreed to sink into the squaw and camp out. You may think I was mad to undertake so much. At any rate, you will look on me as the pioneer of my sex in this wild life. Not at all so, little woman. Even I, in my limited knowledge of the great world, have heard of one Englishwoman who has followed the colonel, her husband, over Himalayan snows and through the deep jungles of the Terai to see specimens of almost all the shyest and fiercest of India's great beasts of forest and mountain fall to his rifle, while another English lady even now camps annually on the peaks of frosty Caucasus.

Up to the present, you will observe from the post-mark, we have only got to Montreal, and have hardly learned to walk with comfort on terra firma.

It was the very end of August before I could tear my lord and master (?) away from those dim and cobwebbed chambers in which he and his law-books dwell.

We started at night, as people going on a long $1-2$ 
journey always should do, making sure of a long day for final preparations, and a quiet comfortable dinner before making the plunge. Even at the outset, the contrasts were striking. One moment you were rattling along beneath the thousand lamps of London, through all the stir and noise of its many wheels and million voices, and as it were the next, the panting of the engine was the only sound you heard as you glided through newly-shorn harvest-fields, calm and still, and white with the dew of dawn.

Here and there my husband pointed out the vanishing brown wings of a covey of partridges which our train had frightened off the line, and then we pulled up suddenly at Liverpool.

This is one of the most uncomfortable stages of the journey; you arrive at Liverpool too early. If after long seeking you find an hotel, it is in déshabille still. The chambermaids in curlpapers are on the stairs, and the waiter looks as if he had only just been roused from a sleep beneath the table. If you visit the ship in which you are to sail, you will find her, too, in curlpapers and the chief steward in an execrable temper. Poor fellow! he has confidently counted on seeing none of the passengers for at least another four hours, and his nerves are not yet braced for receiving them. 
In spite of the unfavourable conditions in which I generally see it, I like Liverpool. It is an amphibious town, and one of uncertain nationality. Its language and manners seem to me to savour almost as strongly of America as its atmosphere does of tarred ropes and salt water, and there is a freshness and vigour about it which seems to me more full of hope and energy than the atmosphere of any ordinary English town.

But enough of Liverpool. Come on board and be introduced to our fellow-passengers, ' homing' Canadians for the most part, who have been loyally celebrating Her Most Gracious Majesty's jubilee in England. Mr. O'Brien, the irreverent Hibernian of our party, calls them 'Jubilee Yanks.' Don't be disappointed, dear ; I really am not going to be even a little bit spiteful about our pretty cousins, for I am fain to confess that they won my heart almost as entirely as they did my husband's.

But not just at first, Lena, for charity (let alone love) is a somewhat difficult virtue to cultivate on board ship towards the young women whose jaunty red hats, blue eyes, and saucy moods have enslaved and carried off the men, whose whole time should be devoted to the arrangement of your wraps and the carriage of your beef-tea. They have not yet forgotten, 
these fair 'Canucks,' many of the wiles of their great-grandmammas, nor lost any of that pretty art of coquetry which those worthy dames imported from la belle France in the seventeenth century. 'Irish mavourneens with French manners,' one of the men called them; but though he may have been a judge of mavourneens, his knowledge of French, at least Canadian French, appeared to us at Quebec somewhat limited. My dear, Madame F., the old French governess at the school where you and I were taught, could not herself make those cabmen of Montreal understand either French or English. To return to the ladies; don't imagine that you will win your way to their hearts by reminding them of any French blood which may be in their veins. On the contrary, if you intend to carry their affections by storm, mistake them for wanderers, like yourself, from the old country. You will soon find that they are more English than the English, and that they "want in the worst way' to persuade you that Canada has no accent and no odd little idioms in her English, and they will 'go hopping mad' if you dare to disagree with them.

If you read your Queen conscientiously, you will find two queries often repeated with regard to sea-voyages. In various keys the wail is 
repeated, but the burden is always the same: 'How shall I avoid sea-sickness, and what must I wear at dinner?' The second question won't bother you much at first, Lena; believe me, you won't risk an entry into the big salon, where the stewards wobble unsteadily, and the soup descends in a torrent on your shoulders for the first four days. After that, if you come down to dinner you will find nothing more needed than a morningfrock with pretty lace fichus and ribbons.

As for sea-sickness, you cannot avoid it. None of the remedies appear to me to be of any good; but whatever you do, avoid sodium. I don't know that sodium is anyone's patent, so I attack it boldly, with no fear of an action for libel before my eyes. It is an innocent-looking little white powder, which in our case was brought on board by a singularly benevolent-looking little lady, who had been taking it steadily for weeks beforehand. The coffin which the ship's carpenter built for that little lady was fortunately not wanted, but she deserved it.

My husband and I chose the St. Lawrence route to Canada, chiefly because it is advertised as the shortest route in open water. So I suppose it is, but the St. Lawrence is no duck-pond, and quite capable of being rough at times.

As to the scenery, I was a little disappointed, 
but you will say that I have seen too much, and am blasée. At Rimouski, the first place at which we touched after leaving Moville, we put a few passengers ashore, losing them and ourselves in a dense fog.

Out of the fog, we steamed slowly up a fair broad water-way between two low, gray walls of rock, hard and bare, looking more like the teeth of a trap than the banks of a river.

Behind these ice-worn rocks lie low, level lands, stretching back unbroken to the horizon, and so flat that the trees appear to rise from the river-bed. Scores of white cottages straggle in a disorderly way along the banks, not in separate hamlets, but in one long irregular line. There appear to be no big houses, and no factories. Such as they are now, the white houses have been for generations, and will be for generations to come. The people who inhabit them care not for great things, but are content to remain men of low estate.

There was something in the still, broad waterway, level lands, and green stretches of wildfowl haunted rush and sedges, which, as we drew near Montreal, reminded me of Holland, and a big, broad-sailed boat (the sail absurdly too big for the boat), bearing down upon us through the evening haze, strengthened the impression. 
Montreal, they say, is an island, but I did not notice this as we drew in to harbour. A mass of spires and lofty buildings seemed to rise from the water, while behind them lay the low hill which bears the proud title of Mount Royal.

It is a pretty town from the water; most towns so seen are; but when you land at the wharf it is just as if you had travelled only from one dock at Liverpool to another. The same smell of tar and ropes; the same nautical shouting and confusion; the same blending of Yankee and Britisher, only here there is a third element, more noisy than either-the French.

You notice, dear, I have gone by the grim old citadel of Quebec without a word. I did so on purpose. One of our many invitations from Canadian friends on board is one to stay at Quebec on our way home and see the town and town life in winter. This we mean to do, so that you will hear all about Quebec in due season.

Of course all Canada should be seen in winter -at least the towns, and especially Montreal, when its glorious ice-palace gleams outside with frosty diamonds, and inside glows with human life and colour; when sleigh-bells make music in the air, and you feel you are in the very home of dear old Father Christmas, in the land of free frolic and winter revelry. 
Summer in Montreal, they say, is too hot for anything but salamanders; but now, in early autumn, the temperature is perfect, the weather exquisite.

Mount Royal is thickly wooded, and just now its woods are bright with colours which would put to shame an English flower-garden.

We wandered up it to-day, discovering a large colony of beautiful little bungalows and cottages, nestling among the woods from base to summit.

The woodwork and roofs of these cottages are painted in the most gorgeous colours ; but colouring which would be offensive elsewhere is here lost sight of in summer and autumn in the brilliance of the surrounding foliage, and in winter stands out a pleasing relief from, and contrast to, the white monotony of the snow.

Most of the cottages are empty, and we met scarcely a soul in the park. The Montrealers are away in the big hotels of Saratoga, in the cockneyfied sporting-grounds of the Adirondacks, or more wisely in the seclusion of Nepigon and her sister lakes.

From the top of the Mount you get a fine view of the rich flat country round the town, if you are not too hot to enjoy it. And, indeed, it was hot. At home we connect Canada in our minds with blizzards and frost-bite, and here 
were we in September, on the highest point in Montreal, gasping for heat. Even the chipmunks were too hot to chatter, and the waterbarrel, with its little tin pannikin, put out on the grass by some benevolent citizen, looked (and was) as dry as a husband's homily on tidiness.

There must be some very wealthy people here amongst the 250,000 who make up the population, for the houses are, some of them, quite magnificent stone structures, with smart grassplots and ornamental trees round them. As the owners and their servants are away or asleep this hot afternoon, the trees and grass-plots are alive with robins. ' Robins,' Lena! I'll trouble you ! birds, my dear, about as big as domestic fowls, with big red waistcoats and heavy gait, about as much like our smart little birds as a Scotch cook is like a French maid.

After 'doing' the Mount, we walked down Notre Dame Street and along the lines of the tramcars, to the country outside Montreal.

But what are the shops like? I hear you ask. Well, dear, there are only two kinds here which would interest you, and if you had such a husband as mine you would not be able to see much of them. What a hurry men always are in when a bonnet-shop is anywhere near! I have seen my better-half almost steeplechasing over the 
perambulators in High Street, Kensington, in his desire to avoid John Barker's pretty windows.

The confectioners and the furriers are the shops par excellence in Canada; and as about half of the shops in the main streets belong to one or other of these classes, we have little to complain of. Red foxtail boas, and a silvery moonlit sort of fur, which they call grizzly bear, are amongst the prettiest exhibits in the furriers' windows; and a box of what the natives call 'mallows,' sent to you by this post, will convey some idea of the confectioner's skill to your palate.

The men chaff us in a superior kind of way about our taste for sweets, but they forget the beam in their own mouths. I mean the cigar. Don't you think it is simply that to suck something is a necessity of the race? Both sexes start level on thumbs; in later life consoling themselves with sugar or tobacco, according to sex. The result in both cases is the same-toothache; and this brings me naturally to a physical trait in our Canadian cousins which is as noticeable as any-I mean their 'golden' smiles.

'A beaux dents femme n'était jamais laide,' you know; but when all nature's pearls are set in gold, how can a woman's smile be anything but bewitching? Really some of the girls you meet carry quite a small fortune in their mouths. 
Tempted by them, I visited a 'dental doctor,' and for the first time passed an hour in one of those terrible chairs peculiar to dentists' surgeries, without suffering any pain worth complaining of. 'Shall I stop it with gold or composition, miss?' inquires the tormentor. "Which do you recommend, doctor?' 'Oh, please yourself; it's your funeral, not mine,' was the queer retort.

From the main street we wandered out by the tram-lines into the suburbs, passing on our way through a poor quarter, where almost all the inhabitants were French. It seems to me that two-thirds of the population of Montreal is French, and quite three-fourths of the wealth English. Along the river's bank, for quite four miles outside the town, a long line of villas takes up every available building site, the gardens running down to the river's brim.

Hospitals and lunatic asylums abound, and (much more interesting) there is a great dairyfarm doing a capital business, ' run,' like most of the milk business of Montreal, by Englishmen. But I must cut my rambles in pen and ink short, Lena, for here are the men anxious to arrange about a visit to 'the kennels,' and a base-ball match to-morrow.

Fancy, my dear, an English club, a racquet court, and the kennels of a well-managed pack of 
foxhounds, all perfectly in keeping with the life that surrounds them, on the very spot where, three hundred years ago, clustered the teepees of the red men of Hochelaga !

Your wandering crony,

\section{J. P. W.}

P.S.-I have just come back from the baseball match, and am not much impressed by the game (which is difficult to understand) or the play. Though unable to judge of it as a whole, I could not help noticing that the fielding was infamous. Catches, my dear, which a village team would have secured were missed over and over again by these 'champions,' and no one seemed surprised. I am told that the long winter, and sodden condition of the ground when the thaw sets in, ruin any cricket-ground which is attempted near Montreal; but even if this were not so, I doubt if our Canadian cousins have the same genius for cricket as those other cousins of ours in the antipodes. The worst trait, my husband says, both of Canadian and Yankee character, is the want of enthusiasm for games which require physical exertion. Almost all the base-ball players, for instance, are professionals, and there is a very serious cash competition for the services of any exceptionally good 
man, while betting on the various teams runs very high. Amateurs are rare in the extremeat least, so we were informed by a Canadian gentleman with whom we travelled. Ah, well; I expect the fact is that the ardent spirits who could find no better battlefield than the cricketground if they were at home in England are in Canada measuring their strength against the wild woods of untamed nature, and winning, not a match, but a livelihood by the work of their own hands, knocking down trees with a girth of thirty feet instead of hitting sixes to leg. 


\section{LETTER II.}

Dear Lena,

Saratoga,

Sept. 15, 1887.

We have been having what our American friends would call a very breezy time of it since I last wrote to you. The men at one time got quite 'out of hand,' and at Plattsburg poor Mrs. W.'s popularity as guide went down a long way below par. Now I am glad to say it is up again to some fabulous point to which my knowledge of Stock Exchange terms cannot attain. Forgive me these phrases, Lena, but what can you expect of a woman who has been living in hotels in which the favourite lounge is like the waiting-room of some gorgeous railway-station, with a bookstall, telegraph office, and 'the latest Stock reports' all within reach of her rockingchair? Now that I am beginning to get used to the ways of this very New World, I am immensely interested, and would gladly stay longer, 
but the first plunge into it is rather like your first plunge in the sea; it leaves you gasping.

On the way from Montreal to Lake George, the traveller must stay at Plattsburg, whence the boat starts up the lake next morning at a terribly early hour. Hotel life does not suit men, my dear, and ten days on a steamer is the worst possible prelude to it. They smoke too many cigars and get thirsty too often, the result being what they call 'liver.' Our three 'lords of creation' had been very good until they got to Plattsburg. There they broke down.

It was a very pretty hotel we stayed at, but there was nothing to do but to sit in a row in rocking-chairs and rock. At supper-time (our dinner) the waiting was infamous; that duty being performed by women. I heard my husband declare that Shamus O'Brien was the only one who could get attended to, and he only because he had such an Irish way of putting his arm round the waitresses' waists. 'No apollinaris, no soda, no whisky, nothing to eat except pickles, and nothing to eat them with except dessert-knives which would not cut butter; a sufficiency of nothing except iced water, electric lights, and brass spittoons as large as Lake Ontario.' So the men grumbled, and when to console myself I 
picked up an American paper (The Doctor, July 1st, 1887) and read there that one of the contributors considered his compatriots 'much less than half baked, so infernally and eternally crude,' I felt inclined to agree with him, and to long for the more mellow manners and greater comfort (without the glare) of the old country.

All American hotels seem to me mere hothouse productions, 'forced,' so to speak, until they have all the outward marks of the last degree of civilized excellence, without any of the thousand and one little things which come of slow growth and a century's experience, and are so essential to one's comfort. But I will stop grumbling if I can, for as in fancy I step with you on board the great lake steamer, to begin our journey down Lakes George and Champlain, scenes of real beauty open out all round us, and if only man were less and nature more, if the great saloon, ' finished in black walnut and butternut,' were a little less noisy than the parrot-house at the 'Zoo,' I could be content almost to sail for ever on those silver waters, studded with isles innumerable, wooded to the very water with dark pine and silver-white birch-trees. I have never read what other people say of these lakes (more shame to me, perhaps), but they strike me as being the cockney camping-grounds of New 
York, just as the Thames' banks in summer are the dwelling-place of the nomadic Londoner.

I said that there are a thousand islands, but on each of them is a camp. On most of them it is a permanent camp. At the head of the lake it is an Indian wigwam which has grown into the Fort William Henry Hotel, a palatial barracks over a hundred yards in length. Over all the lake the same phenomenon is taking place in different stages of completion. Here the encampment is only a little white tent, which gleams prettily amongst the island greenery. On the next island the tent has given place to a temporary shanty of wood, more comfortable, perhaps, but less picturesque; and so the forms of men's shells grow and vary from tent to castle, from châlet to pagoda, but everywhere the pagoda, with red roof and coloured walls, predominates; white boats, red-rimmed, dart out from, or lie idle in, the bays of every islet; every island creek is bridged by white Chinese bridges. At one landing-stage a chorus of picnicking damsels in white tam-o'-shanters come down and spell the name of their camp as a part song for the edification of our passengers; at the next point a gay party lounges in front of a new hotel, whose trim lawns and red gravelled walks look out of harmony with the silver lake which Feni- 
more Cooper sang so sweetly, and on which you listen rather for the war-whoop of the Mohican than the everlasting 'toot' of the steam launch.

You know, Lena, that I am a thorough rustic, that I hold that the coaching meet is almost the only really pretty sight in London, and that I am condemned to dwell with a husband whose tastes are purely barbaric, so you will take my descriptions with the necessary grain of salt. To do the 'lakes' justice they are very, very beautiful, very bright with colour; the local guide-book says 'the tree-tops blush with bunting; shores put on a flannelly hue, and shadowy points blossom out in duck and dimity.' And the guide-book is right; but what I should like to see just once is the lakes at rest, with only the colour of their autumn woods to brighten them; only the blue smoke of a wigwam fire to suggest man's presence, and only the cry of the fishhawk, or the splash of the rising trout, to break the stillness.

We were tired when we got to the hotel, and glad to rest in its vast piazza, supported by a grove of Corinthian columns, until it was time to dine, and felt hope spring again within us as we noticed the number of tennis costumes about the grounds. But we were doomed to disappointment. The American youth wears 'blazers,' it 
is true, and there are tennis-courts, but we never saw anyone playing upon them, or indeed doing anything else more energetic than the smoking of cigarettes and drinking of cocktails.

The Americans work so hard, I suppose, that they have no energy left to play. Rock, rock, rock! went the scores of chairs all day, slowly and sleepily-like the roll of the Pacific, said one of the men; but the boats lay idle. No one rode the saddle-horses, and those who went for a drive only went to be driven.

At one of the last lake-stations we astonished our American friends by announcing our intention of landing and walking the rest of the way round the shore to the great hotel. It was a nine-mile walk, and a walk well worth taking, though the road was six inches deep in sand, making every mile worth two for training purposes, so my husband said. Golden rods and single sunflowers, with a host of other blossoms, of which I do not know the names, mingled with the great ferns by the roadside. Houses, with well-kept lawns and ornamental flower-gardens, alternated with bits of forest or apple-orchards, whose rosy fruit hung temptingly by the wayside. On the lake side of the road every patch of land was either built on or showed some sign of being reclaimed, if it was but a land-agent's 
placard of ' a valuable building lot, with a lake view.' The hotel was chiefly peopled by ladies; the male element appeared to have migrated, and the women seemed so wearied that they had taken (some of them) to cultivating the dramatic talents of the negro waiters, a troupe of whom had recently delighted the guests with recitations and scenes from Shakespeare.

These negroes display, I believe, considerable talent, and a great desire to push themselves in life, some even (here again I speak from hearsay) having been educated at Harvard University. A nigger Othello might pass muster, but Lena! imagine Hamlet done in black!

About the second day our men had tried the fishing, discovered that the trout in the streams were neither as numerous nor as large as the gay little fellows in our Welsh brooks, that a pickerel is only a diminutive 'Jack,' and in spite of a bucket of cockroaches, to be impaled alive, had failed to obtain a specimen of the famous black bass. So my husband threatened Rocky Mountains; and even Mr. L., always amiable and contented, hinted at a visit to the Adirondacks.

Ireland came gallantly to the rescue. Lena, if you ever travel, make a note of this. Forget your Baedeker if you like; your purse if your husband is with you; your music if you really 
don't want to sing; but don't forget to take an Irishman 'along.' They may be a very disreputable lot politically-I believe they are (I'd give them Home Rule if I had one for a husband)but as travelling companions they have no equal. Our Irishman had discovered, whilst teaching his compatriot, the bar-tender, how to make a Manhattan cocktail, that there were races about to take place at Glen Falls that afternoon. In ten minutes he had organized a party to attend them, and I am bound to admit that he took at any rate all the prettiest bonnets about the hotel with him. That was a merry afternoon. Glen Falls is a town of exceedingly pretty houses, peeping out from very wooded streets, and most of its ten thousand inhabitants were at the races that day. The races themselves astonished me. In every one of them there were 'wheels.' No riding, all driving; and such driving! Two large, light wheels ran close against the horse's quarters, and over a little board, supported by the wheels, lay the horse's swish tail, on which sat the jockey. At first I thought I was watching driving-races between tailed men; later on I discovered to whom the tails belonged. All that afternoon the fun was fast and furious, Ireland versus America being a very pretty match in the matter of wit. Poor Mr. O'Brien! I really 
thought his enterprising little companion had completely silenced even him at lunch; for in a pause we all heard this terrible sentence: 'Misther O'Brien,' mimicking his brogue to the life, 'maybe if your mouth wasn't so full I'd be better able to hear what you are whispering in my ear.' Poor O'Brien was very hungry, and very talkative, but, nothing daunted, he replied: 'Sure, lady, it's only my heart that's in my mouth when I'm talking to you.' What followed, history does not record, but surely Mr. Shamus's whisperings deserved a hearing after that.

However, even race meetings would not induce our restless ones to remain at Lake George, where they said you had to pay two shillings for the privilege of bathing in the lake, and the same sum for every article brought up for you from the boat to the hotel. When we landed and walked on to the hotel in the first instance, one of our party left a hand-bag behind him, which he declares was unfortunately open. The contents came out, and were carried up separately at two shillings apiece, by the steamboat people, who have a right to deliver your things (and charge for so doing) if you are not present to instruct the hotel porters to take charge of them for you. The hotel proprietor was very good about this charge, and did what he could, but of course he 
was helpless and blameless in the matter. For the future we determined nothing should part us from our luggage, and when, a day or two later, we arrived at Saratoga, it was very amusing to see the men clinging like bulldogs to their heavy bags and our bonnet-boxes, and resisting all the importunities of the hotel porters, who were anxious to relieve them of their loads, and would not have charged a cent for so doing.

I dare say you will be disappointed, but I am not going to tell you much about Saratoga. I don't like it, and I am tired of fault-finding. I am sure I shall find lots to admire in America, and I like its kindly, genial people immensely; but I do not like its big hotels, with their publicity, noise, and discomfort, and the hotels have been getting bigger and more unpleasant all the way from Quebec, until they come to a climax in Saratoga.

Of course Saratoga is what Bath was, and what some people say Bath is going to be again, that is, a place to drink waters in, to gamble, flirt, and spend money in, and therefore the gayest, wickedest, most amusing place on earth. I don't know whether America is old enough to have the gout; at any rate, she has no lack of curative springs. There is hardly anything, Lena, which you ean find in the chemists' shops at 
home, which you cannot take 'naturally' in one or other of the waters of Saratoga. Take my advice, dear - a little champagne of a good brand is better, and does you more gaod than any of them.

But, after all, the best of Saratoga was a certain evening walk we took when we arrived. The road (I don't know its name) led out of town, was very, very broad, and all along each side of it ran a line of pretty detached bungalows (that is what I should call them, at least), low houses, with fanciful roofs and irregular outlines, with large porches, smothered with flowers, and standing, as often as not, in unfenced gardens reaching down to the trottoirs. All the windows were ablaze with light; pretty pictures of squire and dame, of girls singing at pianos, of all the phases of home life, glanced past as you walked along-too.public for your eyes to avoid them, too private for your good taste to allow you to dwell upon them. The night was so beautiful, the light so bright, the tree-frogs even so musical in the trees, that the only thing like it which I remember is the opening scene in Mrs. Praed's novel, 'Moloch.' I am sorry I ever saw Saratoga by daylight, for, in my case, daylight brought disenchantment. And now, Lena, good-bye. Our party has just broken up. Even Mr. Shamus's 
eloquence could not keep us together any longer. It was a sad scene when, in our private room, he produced from somewhere in his Gladstone-bag a bottle of 'rale old Irish whisky,' and with this and his native blarney tried to keep the men together for another day. But it was no good. Mr. L. will go to the Adirondacks to shoot a stag, which my husband says he will never see except in guide-book pictures; and my husband is off to the Rockies or the Cascades, or somewhere, where people don't wear collars, where people don't need dollars, and, above all, where there are no hotels.

Thine, etc. 


\section{LETTER III.}

Victoria, British Columbia.

Dear Lena,

It is almost impossible to believe that I am not dreaming. Sitting by the open window, the drowsy summer air comes in off the sea and fans my forehead; from the lawn outside I can hear, 'Well played,' 'Love thirty,' 'Deuce,' and other scraps of tennis jargon from lips of English men and women. In fancy I can see the gray stone walls of your old English rectory and its wreaths of blue clematis ; but if I open my eyes, they look, it is true, across green tennislawns and past English players, but the skies are bluer than those skies of Gloucestershire ever were ; instead of the Cotswold hills are the snow caps of the Olympian mountains, the houses round me are of timber instead of stone, and just beyond are pine-forests, in which the trees are so vast that a single one of them contains almost as much timber as stands in an English wood. 
The room I am in is full of English trifles, the things which seem to grow round a woman : delicate: ornaments, frames and photographalbums, full of honest English faces; but if I ring the bell, a pig-tailed Chinaman in a profusion of beautifully white linen will respond (at his leisure) to my summons, to remind me that I am on the very Western brink of the world, with 6,000 miles between you and me.

You know how we wandered about until we got to Ottawa, for I wrote you all the news of my travels up to that date. Let me pick up the thread of my wanderings at that fair city which has already had three names at least, none of which seem, to my mind, to fit it. Neither Bytown, nor Hole in the Woods, nor Ottawa, should it be called if I could have my way, but just simply Lumber-town, because it is the capital of Canada, and lumber has made Canada ; because it lies in the heart of a lumber district; because lumbering (next to legislating) is its principal business; its waters are red with dust from the lumber-mills; its streets are full of the lumbermen; its air is full of the scent of lumber fresh sawn, and standing on the terrace of its really beautiful Parliament Buildings, you look across a broad river, the high-road of millions of logs from the central lakes, on to acres and acres, nay, 
miles on miles of timber-yards, piled high with planks and boarding ready for export. It is wonderful, standing beside the falls, to see the logs come shooting down the slides prepared for them. Up stream you get a glimpse of heavy waters gliding on to the brink of that caldron into which they eventually rush, waters gliding down from distant woods, whose fringes of birch and maple you can just see: down stream the spires and buttresses of Parliament Buildings, from their overhanging cliff, are mirrored in the waters. On one side the bridge on which you stand are the falls, on the other the saw-mills. At the foot of each mill is a pool, into which one after another the logs come swimning down, after their many weeks' journey through wood and waste. Standing there waiting for them are two or three men with big gaffs in their hands. Selecting a $\log$, they strike their gaffs into, it, drag it to the foot of a little ladder, attach a hook to it, a wheel grates and goes round, and the dead tree slides up the ladder, passes through the jaws of certain great steel instruments, and in three minutes is ready cut and trimmed humdrum everyday 12-inch boarding. A cent a foot for the pine that has grown a hundred years in God's free air and sunlight; listened to the throbbing of the breezes in its branches, to the roar of the, falls 
below, or the live thunder among the mountain peaks. I felt sorry as I looked, and almost angry that the pine's majestic beauty should be sacrificed and turned to such humble uses.

Ottawa, I believe, is gay enough in its season; it looks bright even in the dead time during which we visited it; but, of course, when the House is not sitting, Ottawa sleeps. The little town (for she has only 40,000 inhabitants as yet) has a very English tone about her, and is right loyal to the sovereign who gave her her preeminence among Canadian cities.

Even the flowers round Parliament Buildings were so trained in this year of Jubilee as to spell with their blossoms a loyal greeting to our Queen. On leaving Ottawa we settled down steadily to a week's railway travelling, more or less. 'No more stoppages' between this and Vancouver was our watch-word. My husband was tired of hotel life and pining for barbarism. All men, Lena, revert quite naturally to barbarism, and I honestly believe, were it not for our benign influence and the necessity of providing payment for milliners' bills, etc., a great many of them would even sacrifice their clubs for the supreme pleasure of working with their hands in the open air rather than indoors with their heads. And really, seen from a comfortable Pullman car, this war of man 
with Nature in her very wildest moods looks wonderfully noble and attractive. I would myself much rather be a slave and have someone to look after my comforts and be responsible for my daily bread; but for anyone who loves absolute freedom and is strong enough to survive in such a state, earning all he wants by his own unaided exertions, this pioneer life in America must be perfect. I don't wonder at the pioneers holding their heads high; at their little boys, hardly old enough to play marbles, carrying sixshooters and talking like men; for though you are not making a fortune, it is something to feel that the house you live in, you built; if it wants repairing, you or the boys must repair it (no plumbers or carpenters to send for here); the fields you till, you reclaimed; the bread you eat, you grew ; and that though from your doorway to the sky-line there is no neighbour's house, though the prairie stretches like a vast untenanted ocean round your tiny cottage, you are in yourself strong enough to live there, unaided, self-supporting, 'boss of your own show,' as they quaintly phrase it.

On leaving Ottawa the C. P. R. has at first to force its way through a land of dense forests and lakes. Inside the Pullman car all is luxury ; outside is Nature in her most rugged mood. The 
cars are on cradle springs, and rock evenly as they rush along the line. Lying in a cosy bed, I drew up the blind of the window which ran beside my pillow, and as I dozed away looked out upon the wild Canadian night. The tall telegraph-poles, just noticeable here and there amongst the forest trees, were (in those first few hours en route) the only things beyond the line to remind me that man and nature had yet met in the districts we were traversing. Forests rugged, gray, and stunted, swept through at no distant date by fires; streams fighting for a passage through the rocks, or crawling sluggishly through the muskeg (peat); night mists rising from river and lake, and a long pennon of our smoke floating over all in the moonlight-these were the things I saw as I lay dozing, or which wove themselves into my dreams, while the airbrake sighed, and the engine screamed like a banshee, flying through the night from Ottawa to Nipissing. An inviting outlook, perhaps, for the hunter, angler, lumberer, or miner, but surely there is no room here for the settler. No human courage, I thought, could tame this wilderness; but I was wrong. Daylight showed me towns where men seemed busier than they are at home, where houses were being built out of the trees just felled to make room for them; 
where everyone seemed, if I may coin a phrase, to be working a quicker stroke than in the old country. How they earn their bread I cannot tell; but I suppose this region between Ottawa and Lake Nipissing owes more to the saw-mill than to the plough; at any rate, no one-seemed to have time to go about informing the world that 'they'd got no work to do, and Eng-i-land, poor old Eng-i-land, is agoing down the 'ill,' as I heard the men doing at home before I left. All the first day we were whirled at about the rate of twenty miles an hour through trapper-land, where until lately the only sign of civilization was at some Hudson Bay Company's post, whose agents gathered together year by year the fur harvest of the red men-hunters who, after a long summer of idleness, used to turn out into the woods in winter, with the thermometer sometimes forty degrees below zero, and earn by their hard work, abstinence, and exposure some 1,300 dollars apiece to spend in many-coloured blankets for their squaws, and whisky, when they could get it, for themselves. We saw a few of the redskins at the stations-painted beauties of the Ojibbeway persuasion, engaged in earnest endeavours to pass off cows'-horns neatly polished as horns of the buffalo of the plains. It is quaint to see two or three of these women wrapped in red and 
yellow blankets, their faces coloured as brightly as their blankets, feathers in their hair, and a papoose on their back, followed by a squalid, washed-out-looking chief in an old stove-pipe hat, coat, and pantaloons, shuffling along in boots very much down at heel.

You must not expect me to take you along the line and describe every place as it occurred, or even every district. The people in the cars were far too interesting to allow of my making notes, and I can only give you some sort of general picture from memory. My impression is, that for two days we traversed forests stunted by cold or withered by fires, amongst which the groundmaples and dog-wood glowed with colour, repeated every now and then on huge boulders of gneiss and granite. Here, in spite of nature, we came now and again upon a spot whereon the railway navvy's hut had remained and grown to a poor cottage, round which long strips of halfcleared land and a hundred or two of charred stumps marked the first step in the founding of a new town. Further on we came upon a town of newly-built frame-houses, looking somewhat drearily out of blindless windows into the forest round them. Hard bronzed men, axes in hand, blue-frocked Chinamen, and an Indian or two, were at work still building the young city. A 
girl alighted here from the train, fresh from the comparative civilization of some town of five years' older growth. Her dress showed she had just come from the great world. A pair of white silk gloves reached to her elbows, and (Heaven forgive her !) she wore an 'improver.' But the gentleman in flannel shirt and cowboy hat, with enormous moustaches and eyes which must have come from Ireland, was not appalled even by the dress-improver, but just dropped his axe, removed his pipe, and received the wanderer into his sinewy brown arms with an energy discomposing, I fancy, to the improver, but satisfactory to its happy possessor.

This was the second stage. The navvy's hut had become the centre of a small town; one man's pluck and labour had drawn others round him, and springing, in a few years, from the same small source may rise a Chicago or a Vancouver. Who can tell? Mushrooms do not grow as fast for their size as these Western cities.

Then we plunged into the region of lakes. First we came upon a little one, Lake Nipissing ! Look at it in the map. Compared to Lake Superior, it is as a grain of barley to the bowl of a table-spoon. But Nipissing is 90 miles by 20 . Not such a drop in the ocean, after all. 
Round and about these lakes the line turns, skirting their shores, which may teem with game, but certainly are very scantily peopled by man.

For 300 miles from Cartier to Heron Bay, the forests belong to the deer, the lakes to the fish alone. Man has hardly yet explored this section of country, unless it be some wandering redskin or daring white hunter.

What a land this is for an angler! All along the line lie tiny lakes like gems among the timber. On half of them probably no birch-bark canoe has ever floated-no fly ever been thrown. There is always a mystery and romance about fishing new water, you are so uncertain as to what the shadowy bays among the weeds may contain. But here all the charm is doubled. If we could have done it, my husband and I would dearly have liked to stay at one of these pools, and match the supple strength of an 'Ogden' against the rush of the monsters which dwell in the shadow of those pines.

Several times during the journey good 'takes' of fish were put on board the train by men who make a business of supplying the dining-cars. The trout they offered for sale ran from three to twelve pounds, and were excellent eating.

Among these Canadian lakes you cannot help feeling that it is not far to the Arctic regions of 
Hudson's Bay. Everything is so solemn, almost sad. Looking back upon Lake George from the shores of Lake Superior, the contrast between the tawdry gaiety of the one-its big hotels, painted pagodas, gay boats, and everlasting steamwhistle-and the grandeur of the other's loneliness is very striking. From the lakes we emerged through woods growing hourly more sparse and dwarfed, upon the black, damp-looking lands round Winnipeg. At first, they tell me, these lands were thought too wet and heavy to be valuable; now they find that only such lands as these will hold sufficient moisture through a summer drought. During the boom, an acre near Winnipeg sold at from 50 to 100 dollars, and the result of these prices is seen on all sides. There are pastures, but very little stock; farmers, but comparatively little farming. That, at any rate, was our impression, though Winnipeg people, after their wonderful growth from a village to a people of 30,000 strong in five years, are not all inclined to admit that this is so. Others, though, will tell you that those who hold land have beggared themselves to buy it in the hope of a rise, and are now paying rates and taxes on it out of their other sources of income rather than let it go at a loss.

From Winnipeg westwards the landscape is 
an unbroken sea of silky yellow grass or arable land. A few white farms far off the line, or a clump of hay-ricks, may now and again break the level of the horizon; but the land seems to have no feature but immensity, no character save loneliness. What it lacks in outline, Nature has made up to it in colour. Golden sunlight seems to dwell forever in the soft prairie grasses curtseying in endless ripples before the prevailing wind. The round, small lakes at which the buffalo used to water are bluer than amethyst in the sun; here and there the alkali round some larger pond glistens like burnished silver, and as we look forward along the perfectly straight pathway of the line, a great red sun comes down in glowing splendour, touches the white cottage of the pioneer, and decks its meanness with golden purple, and sinks in a flood of colour right between the rails. In the morning we are by the Saskatchewan at Medicine Hat. There is wilder scenery beyond, but none which struck me as being ruder. Surely here Nature must have made her first essay, flat mud, yellow and uncovered with herbage, rolling as far as the eye can see under yellow sunlight. A monotonous river and a few Indian teepees alone vary the outlook for half a day.

The next day we passed through the land of 
the cattle kings ; passed Calgary ; were visited by the North-West police-as smart men, my dear, and as soldierly, as any who carry sword or musket -and then began to climb the Rockies. It is just as well that some parts of the journey are done at night, for if there were any people with nerves on board, the views, however picturesque, would be too much for them. Trestle bridges over cañons of infinite depth sound very well, but it makes your hair stand on end to look at them. Railway trains which appear to curl round the edge of precipices on one wheel, the other being over an abyss, are interesting when you are not in them. At first I was decidedly nervous. Byand-by this wore off, and I enjoyed sitting on the step behind the last compartment, one foot dangling over the edge of a precipice, at the foot of which a mighty river boiled along unheard, or forests of great trees were dwarfed into insignificant larch plantations. Upwards, ever upwards, we went, getting slower and slower until the top was reached, and we were fairly in wonderland, passing along a frozen plateau through an avenue of snow-capped peaks. "Surely these are not the highest peaks we shall see ?' I asked, pointing to Mount Stephen, a grand cluster of sharp peaks, but not near enough to heaven for my ideal monarch of the Rockies. 
' You forget, madame, you're 5,800 feet above sea-level yourself at the present moment.'

I apologized and acknowledged that that was an enormous height for a railway line to attain to, but I rather agreed with my husband's growl : 'That only makes it about 13,500 feet altogether, and I don't call that much of a mountain.'

Having traversed the Rockies, we crossed the Selkirks - a far wilder-looking chain than the first, swooped down into the flat country again, knocked the inside out of our engine against a boulder on the track, had a car or two run off the line, but, thanks to the excellent air-brakes, and a clever and watchful pilot, came to no worse harm than a few hours' delay ; were then, in recognition of our valour, turned into a 'special,' which ran at an increased rate of speed over places which would have shaken less seasoned nerves, almost ran into a splendid stag on the line above the Thompson, and then stopped outside a tunnel while the line was relaid, and a trestle bridge repaired which connected two short tunnels in the cliff overhanging that grand river. But for this stoppage, due to the vigilance of the line-watcher, we should have taken a header of several hundred feet into the river. After this the lands grew level and more level, the timber thicker and ever larger and larger, until we were amongst the 
giant pines of the Pacific coast at the newest of new towns, Vancouver. Thence a pleasant eight hours by steamer through still waters, set with hundreds of pine-grown islands, and enlivened by a surprising number of peculiarly familiar whales, brought us to the haven of rest from which I am dating this letter. Altogether the journey can have no parallel, Lena, in the world. Made when we made it, in the cars you suffer neither from heat nor from cold. Your only regret is that the scenery outside is so superb, that you cannot devote enough attention to your fellow-passengers, and your fellow. passengers so amusing that they distract your attention from the scenery. One of my friends en route was a lady from Washington Territory, going back after a visit to Lower Canada. Years and years ago she had been one of the passengers in an 'emigrant train' (of waggons drawn by mules) across the country of the Blackfeet, a land in which she guessed 'your back hair generally felt pretty loose.' She had come to Washington Territory when quite young (before it was a territory, I believe, if anywhere in America is ever as young as that), 'to grow up with the country.' And she had grown up with it, but her ideas were somewhat conservative (and I thought sensible) for all that. Three 
years back she told me they enfranchised the women of Washington Territory, and now they were trying to disfranchise them again, ' and I hope,' said my friend, 'that they'll succeed. Why, now they make us do all manner of things ; sit on juries in all sorts of cases, however bad they are, along with the men. Some of the women like it; I don't. If you've got a child two years old or under, you are exempt from serving; but very few claim their exemption. You see, women get three dollars a day for serving, and some of them like a law court better than a theāyter, and bring their baby along rather than stay away. I was called on the Chinese riot case, but the marshal, who found me cleaning the kitchen-floor, let me off coming.'

Some of the people on board were charmingly simple and unaffected, knowing very little of the old world-men and women who had been so busy all their lives making a new world, that they had had no time to look back at the old. Others were so widely travelled and deeply read that no land seemed untrodden, no book unread by them. Domestic life in your own little house in England, with your own little cares and your own snug pleasures, is very comfortable, Lena ; but just now I feel as if it were all very small. 
I believe half of us want shaking up and sending out to these new lands which are our beautiful birthright. If it was not that we feared our friends would find the cause of our emigration in home failure, how many of us would have been off long ago to the land of promise! You must come with us another year to this world of giants; look for yourself on these last desolate fastnesses of Nature assailed by the coming of man, where, though we no longer build our tower of Babel to the sky, we drive our steam-horses to the mountain's top; see it as I see it now again in memory, snow on the ground, mist in the night air, through which, from the boulderstrewn mountain-side, rise tall stiff pines and dark funereal hemlocks. Silence reigns, and the bear and wild big-eyed mountain beast are alone in the forest and the night.

But the moonbeams fall on other tracks than the bear's in the snow. Straight as a bird's flight runs the narrow trail, straight from east to west it runs, and the moonlight glistens on the iron rails. Anon a wild shriek wakes the echoes, weird and long drawn and full of agony, wilder than the wolf's howl, more weird and shrill than scream of panther or redskin on the warpath. Through the mist a vast bulk approaches, like the body of some great serpent. A beast of 
iron drags it from in front, a beast of yet larger size propels it from behind. Like the Cyclops, each beast has one vast red eye in his forehead; his hot breath reddens the surrounding gloom; the throbs of his great heart break the stillness as he labours with his mighty load; the Sisyphus of the Canadian Pacific is enduring his ever-recurring toil; frightening the red deer in his couch, and leaving behind him no trace but one long plume of smoke trailing down the night wind.

Ah, I think I had better stop. If I go on thinking of that journey I shall begin to write poetry, or commit some other atrocity against which you will very rightly rebel.

Au revoir.

Thine,

$$
\text { J. P. W. }
$$




\section{LETTER IV.}

\section{Dear Pat,}

Princetown,

Sept., 1887.

Forgive me for disappointing you. This huge letter is not from a solicitor, and, in spite of the blue envelope, has nothing to do with law. No letter, I think, ever travelled between points so different as the starting-point and goal of this one. Here, thank God, is barbarism and fresh air and sunlight; with you civilization, and, I suppose, fog ; though really, what with Mrs. C.'s objection to window-cleaning, and the mole which the benchers have builded between us and the tennis-courts, the question of fog or sunshine is not one which need interest us much.

Hurl those musty law-books across the chambers, and for ten minutes try to imagine that you are with your chum in British Columbia.

'Four cock pheasants, four grouse, ten quail ; 
total, eighteen head-not bad for Victoria, eh, my boy?' quoth Charlie V., a week ago, as he unloaded himself before his admiring wife and myself in the back kitchen, while the smug little Chinaman said a savage but silent swear at the mess Charlie was making.

' You had much better stay here with your wife, and come up duck-shooting later on, instead of going all the way to the Ashinola country,' he continued; and for a moment, when I thought of the terrible crowd who had gone before and were coming after me, I almost consented to remain, for Charlie's ways are seductive, and his cooking distinctly excellent.

I had come about 6,000 miles to try a country of which I had heard four years ago, and on arrival was told that there were two parties of Americans already 'in,' that others had preceded them and come out, that at least one party of Englishmen were making their way to my happy hunting-grounds from a point further east, and the greater part of the officers of H.M.'s Navy intended to follow shortly.

Things certainly did not look promising, but some people hate to change their plans, and I am of this sort; so that dinner over, and the last cigar smoked, I belted on my smaller impedimenta, shouldered my rifle, put my tent in a cab, 
and at 1 a.m. was on board the boat for Vancouver. Here I divested myself of that badge of civilization, a collar, wound a comforter round my neck, and prepared to settle down to the enjoyments of barbarism. But I was not free yet. A friend arrived, and begged ere the boat started to be allowed to introduce two brother sportsmen. Good fellows they were, too; but why brother sportsmen? Surely there is no one to whom you feel less fraternally inclined than to 'that other fellow' who happens to be going to shoot at the very spot you had marked for yourself at the very moment at which you mean to visit it.

Of course, these two 'brothers' were going to the Ashinola country, but luckily by another and, it seemed to me, slower route. I parted with them at Hope, a station not ill-named as far as we were concerned, for as our train rushed towards it we saw a young black bear scuttle off the 'track' into the forest, a sight which we accepted as a good omen for our trip. At Hope a wooden shed and platform stand alone beside the rails; around is forest; below, a broad bend of the Frazer River ; beyond, an amphitheatre of mountains, grim and forbidding, sparsely clothed with the gray stems of pines, blasted by fire or frost; while on the other side the river a few 
wooden houses peer out timidly from the edge of the timber.

I was the only passenger who alighted at Hope. For a moment the great engine drew up. Friends bundled my tent and belongings out after me, gave me a farewell grip of the hand, the engine whistled and hurried off into the forest, leaving me alone on the wrong side of the river. The last glimpse of civilization was the tail-board of the train, as it swung round a rocky bluff, with a certain old soldier-lord upon it, bare-headed, waving a cheery adieu to me, his chance acquaintance. May Canada never see a worse sample of our army than that keen, kindly sportsman! When I turned round, the nearest approach to a human being in sight was a Siwash postman. A little pantomime, in which the leading parts were taken respectively by a 50 cent piece and my luggage, then ensued. At the end of it the Siwash shouldered my baggage, and pocketed my 50 cent piece, and anon paddled me across the broad Frazer to the town, his fare sitting humbly at the bottom of the canoe, and carefully tying the rifle to the seat in case of accidents.

Before leaving Victoria, I had telegraphed to Mr. Wardle, the local magistrate at Hope, to get me, if possible, horses and guides. On arrival 
I found Mr. Wardle, a stalwart Anglo-Saxon, in his shirt-sleeves, proprietor and manager of the large store which supplies the inhabitants of a hundred miles of mountain and forest with all they want, from photographs to flour.

The canoe ground against the shingle; we stepped out into the middle of the grand promenade of Hope, dropped our bundles in front of W.'s store, said ' how do ye do' to the crowd of seven collected to meet us, and were at once in the heart of Hope society and fashion. In another ten minutes my guide arrived, a tall, gaunt, white man of many summers, named S., together with his half-breed son, my future cook. Long practice in camping-out expedited our arrangements considerably, and by nightfall stores were bought, horses secured, wages contracted for, and even some of our bales packed. 'Start to-morrow at ten sharp,' were the last words at parting that night; and in spite of the nods and winks of his neighbours, jealous at S.'s luck in getting the job, the old man was not drunk next day, his horses were not missing, and we were only two hours late in starting. If you want things done promptly on the march, you must not loaf yourself, but bear a hand and urge on all preparations to the very last in person. See everything 'fixed,' and then no last glasses! 
Swing yourself into your saddle and ride on; the men may dwell five minutes, but if they see the 'boss' has gone they will soon follow. And so I found it, for hardly had I lost sight of Hope and entered the forest, when I heard the trot of my baggage-animals, and the jangling of the leader's bells. In all my other shooting or exploring expeditions, I have travelled light and gone hungry. On this occasion $I$ was determined to 'do' myself well. For the benefit of any who want to know how to arrive at similar comfort en route to their shooting-grounds, I offer the details of my equipment. I am bound to confess I look upon my outfit as luxurious in the extreme, but as a party of Americans preceded me, with a squadron of baggagehorses bearing ' light groceries,' including champagne and a mahogany night-commode, my own seemed to the guide of Spartan simplicity by contrast.

With me I had a man and a boy, three horses for packing, and three for myself and the men to ride; two tents (a big one for them, and a little one for me), two axes, two frying-pans, a teapot, together with stores, of which I annex a list. It is Mr. W.'s bill, and gives fair idea of stores necessary for four people for a month, and the cost thereof. 
Sept. 25. 1 sack flour, $\$ 163$ c. $\quad$. . . . . 163

" 6 cans yeast powder, $25 \mathrm{c} . \quad$. $\quad$. 150

"24lb. spice roll bacon, 18 c. . . . 432

" 2 tins 3 lb. lard, 50 c. . . . . 100

" 25lb. granulated sugar, 10 c. . . . 250

" $22 \mathrm{lb}$. tins coffee, 75 c. . . . . 150

" $2 \mathrm{lb}$. tea, $50 \mathrm{c}$. $\quad$. $\quad$. $\quad . \quad$. 100

" 1 can pepper, 25 c.; 2 sacks salt, 20 c. . 45

" 3 packets matches, 25 c. . . . . 25

". 1 bottle Worcester sauce, 10 c. . . 40

" 10lb. onions, $7 \frac{1}{2} \mathrm{c} . \quad . \quad$. . . . $\quad$. 75

" 10lb. beans, 5 c. . . . . . . 50

" 6lb. dried apples, 18 c. . . . 108

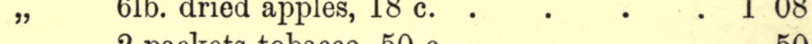

" 2 packets tobacco, 50 c. . . . . 50

" 1 axe, $\$ 150$ c. . . . . . . 150

" 1 bottle sweet oil, $25 \mathrm{c}$. . . . . 25

" 4 flour sacks, 40 c. ; 2 yards berlass, 50 c. $\quad 90$

" 2 grain sacks, 30 c. . . . . . 30

" 1 pair gloves, $\$ 1$. . . . 100

$\$ 2133$

It was September 25 th when I rode out of Hope on my buckskin pony, the maples and other shrubs glowing like red embers with autumnal colour from among ruinous gray boulders or the cool shadow of the pines. The cedars were alternately red and green, their needles dying slowly ere they fell, while here and there a mammoth pine reared its two hundred feet of height towards heaven, ending more often than not in a dead-white branchless spire.

Along the track there was absolute silence, 
except for the chatter of a chipmunk, saucily regarding us from the end of a hollow log, or the call of a crested grouse, flirting its tail in air as it strutted unconcernedly out of our way. Onee only we met a man, type of the men who have peopled these wildernesses, a tall, fair-bearded giant, in dark blue flannel shirt and canvas trousers, striding along, rifle in hand. As eaptain of a lumberers' camp he had saved a little money, and was now returning from a walk of nearly two hundred miles, taken alone without blankets, through mountain and forest, for the purpose of finding a bit of country fit for a ranche for himself and two other Scotehmen, his brothers. Sometimes, of course, he came across Indians or a pack-train; as often as not he met neither; and then, putting on the coat he had carried all day, he lit a fire and slept wherever he felt inclined to rest, sleeping as happily by the roadside as the Londoner in his hotel. Our halting-place the first night was at the 'fourteen-mile' house, a rough log cabin, kept by a white man of solitary tastes and sanguine temperament. Sanguine he must have been, for he only charged us two shillings per head; except packers he hardly had a dozen guests per annum, and he expected to make his hotel pay! Down below the cabin was a swamp; low land untimbered, with a few sal-lal 
bushes about it, and through it dawdled the slowest of streams-a stream, however, whose waters were clear and pure in spite of the milky blue colour which spoke of their glacial origin. This stream, they told me, contained trout, though they had not been rising lately. The first cast in one of the pale blue pools showed me that there were fish there worth having and willing to be had. As the flies went out over the first pale blue pool, its surface was troubled, and as they lit, two great trout came half-way out of the water for them, felt the steel in their lip, and, before I had recovered from my surprise, had smashed my trace, and carried off two very old lake-trout flies to the bottom. I lost two more old Norwegian flies which had long lain rotting in my book before I took the hint that good fish, however simple and confiding, require good tackle, and in accordance with that sound theory, selected a reliable new fly from the scratch lot which I had put up before starting, and settled seriously to my work. The wild salmo fontinalis of the cascades may smash the gut and make light of flies bought years ago in some shop at Bergen or Trondhjem, but an alder of Ogden's make is another matter. I admit I am an enthusiast, and pig-headed about that fly, but I have reason to be. When the green drake is on, 
on our own chalk-streams, and the fish are almost too dainty to take the natural fly, let the light wings of a big Fairford alder go by, and you have him. In the still evening, when the big fish feed in the calm broad waters, sink and draw your alder gently towards you, and just as it nears your feet, a mighty rush will set your heart throbbing and your reel screaming. So it was here. In a moment I was into a big fellow, and, ye gods! how he fought! how savagely he headed for an unpromising looking stake, whose broken end rose from the other side of the pool! But the gut held, and at last I piloted him safely through the sunken $\operatorname{logs}$ and boughs which fringed the edge of the pool, and knocked him on the head, first of two dozen, whose rosy sides glistened that evening on the pebbles behind me. At last one fellow, whose quiet rises had long drawn my attention, broke the top of my rod, tied me round the stake which had imperilled every fish I had hooked, and broke the only alder but one in my possession. So I carried my spoils up to the hut, and shared their bright yellow flesh with certain young Englishmen who had just arrived from the country whither I was wending my way. With them was an old trapper named Chance, who had learnt the country as a gold-miner and prospector, and had just piloted 
them out from the mountains, amongst which they appeared to have had no sport, and to have been lost. But they were philosophers, 'could not expect anything better the first time,' admitted that they had shot badly, and altogether took their bad luck in a way which augured well for their success should they ever try again. The one thing that stuck in their throats was that in the last ten miles they had been walking with Chance ahead of their train, without their rifles, when, of course, they met a black bear sunning herself on the trail. When she saw them she moved off very leisurely to the woods, while they went back for their shooting-irons, old Chance going on slowly. On their way to rejoin him they met Chance, very anxious indeed to see them again, having run up against a 'bald-faced' grizzly directly after they left him. Being anxious to go by, he shouted and threw a 'rock' at the bear, who came down on all fours, and trotted quietly towards the trapper, rather in a spirit of careless inquiry than of anger. As Chance put it, "When I saw him climb down, you bet I climbed up and put for camp,' where he arrived scared and out of breath. I don't know whether the Englishmen with Chance quite believed his story, but I frankly confess I did not; and when he advised me to climb a tree if I 
met a 'bald-faced 'un,' I was sorely afraid I should never have a chance of following his advice. However, I started next morning some time before my men on the young buckskin mare which old S. said was a good one, but not bridle-wise (i.e., broke), in the hope that perchance, if I kept out of earshot of the bells of the pack-train, I might at least meet skymaquist (the black bear), even if his cousin kheelounha (the grizzly) should not honour me with an interview.

The trail through the Hope Mountains leads through heavily-timbered gorges, at the bottom of which run mountain-streams, while above you rise the peaks towards which climb dense forests of cedar and pine.

At first I trotted along a good level road through a low wood of young timber, through which the morning sun shone cheerily. From time to time my horse and I even indulged in a canter from pure good spirits, and to get away from the bells. Here and there we passed old camping-grounds, where packers or cattle-men had made a night of it.

Grouse flustered up among the trees by the roadside; the stream below glittered as it ran, the snow on one high peak gleamed like silver in the sky, and the sun glowed through the mapleleaves as if they were red wine. 
Anon we entered a gulch, leading ever lower and lower down the cañon. The trees closed over us, the sun was shut out, and with it light and colour. The change was very marked. The silence seemed oppressive, there was no stir of animal life, and both my spirits and the horse's became distinctly chastened. Men are like children, and horses like both : their courage rises in the sunlight and ebbs in the dark. The road at last took a turn under a steep moraine, on whose gray side the frosts and damps of midnight seemed to hang from ' everlasting to everlasting,' while round it fire and ice slide had worked grim chaos among the old pine-trees. We were distinctly depressed here, my horse and I, when suddenly the only ray of sunlight which had ever invaded this 'dark profound' struck on a brown mass in the path in front of us, not ten paces from Buckskin's nose. Silently it rose upright, making (as far as I could hear) no sound at all. Buckskin simply sat down, her forelegs stuck straight out and her ears pricked, frozen with fright. Like a stage demon the grizzly had risen from the path in front of us without warning of any sort, and, for a moment, I considered the question of flight, and the improbability of anyone in my little world at home being any the wiser if I bolted. . However, it was easier to get 
off and shoot, so I dismounted, put my arm through the bridle, and prepared to take a solemn pot-shot at the old rascal who was stopping the Queen's highway, standing up, right on end, in the orthodox fashion of the storybooks. This, I confess, astonished me, for having shot a good many bears 'of sorts,' and having never seen one do this before, I had until that moment thought grizzly's uprightness a good deal overrated. But my deliberate movements were too much for 'old Ephraim,' who promptly came down from his post of observation, and before I had time to fire, gave one quick lurch, and was gone into the bush, as quickly and as silently as if he had been only a British bunny caught sitting in the sunlight on a woodland ride at home ; and all that was left of him was a little column of yellow dust curling up into the ray of sunlight in which he had been dozing. Not being young enough to attempt to follow the bear into the thicket (having once, long ago, nearly lost my life by such folly), there was nothing to be done but to get back into the saddle, whence I could see over the little jungle, wait for my pack-train, and watch for a chance of a shot in case the bear should try to break away. By-and-by, after what seemed an age, I heard the bells of my laggard train, and saw 
them file out one by one from the timber on the way to where I stood. A low whistle sent their heads up, and a few hurried words explained the state of affairs to old S., who was to keep the train at his end of the thicket, and, if possible, turn the bear in my direction. The first shout roused the bear, who strolled out on to the moraine opposite to me with the greatest nonchalance, and was, I think, going to sit down to have a better look at us, when a bullet from my express caught him in the ribs and rolled him over. I was on the horns of a regular dilemma when the bear broke covert. If I dismounted I could not see to shoot over the bushes, whereas, if I fired from the saddle, $\mathrm{S}$. warned me that the young mare was not 'bridle-wise,' not used to having shots fired, and would buck me down the cañon to eternity. Reflecting that, at any rate, if bucked into eternity I should at least be safe from the bear, I dropped the bridle on the mare's neck, and turning round in the saddle, took a good steady shot at him. The moment he felt the lead he dropped, and then came round with a snarl which sounded like mischief. But the gallant little mare stood firm as a rock, enabling me to put another bullet in, which frustrated any amiable intentions our friend may have had, and compelled him to lie down. The men gave a 
cheer at the result of the two shots, and we watched a little anxiously while the bear stretched his strong fore-arms in his last throes. As he did so, a hollow growl or groan sounded in the thicket behind us, eliciting from my old guide a horrified exclamation of 'My God! there's the old one,' whilst for one moment I feared there would be a general stampede from what was really only the last effort in ventriloquism of a dying bear. But the men stood, and next moment we were laughing over the odd illusion, while cautiously forcing our way through the brake and up the moraine to our quarry. There was a good deal of stoning done, to make 'quite, quite sure' that he was dead; and then we skinned him, and set up his naked carcass as a warning to his tribe, and an advertisement to other travellers of our success. As we tugged away at his skin, old S. gave a little lecture on natural history as known in the Hope Mountains, pointing out, amongst other things, that when disturbed by me the bear had been taking a breakfast of white-willow berries, as an aperient before turning in for the winter, now close at hand. According to S., the bears are in the habit of going through a regular course of medicine, ending with large doses of dead rotten wood, taken to stop and counteract the effect 
of the willow-berries, just before hybernation actually begins. I tell these stories because I think local traditions of the habits of game are always worth listening to, even if you cannot believe in all of them.

Good-bye; the packs are fixed, S.'s pipe is lighted, and the train is moving off along the trail, while Buckskin is tugging at her tether and looking unutterable things at me, because I do not invite her to join the march,

Thine, etc.,

C. P, W, 


\section{LETTER V.}

Dear Pat,

Alison's Ranche.

Travelling with a pack-train is very monotonous work, especially when your time is limited, and a land full of great game, and therefore great possibilities of happiness, is before you. It seems so ridiculous that the pack-animals should not be able to do more than three miles an hour ; so exasperating to see your men sitting half asleep in their saddles; to see some obstinate brute of a pony calmly stopping the train in a narrow place to nibble leisurely at the sparse herbage, conscious of your inability to get at him. But there are worse things than these. It is afternoon, and you have ridden on very slowly, determined to be quiet and endure the inevitable, and enjoy the scenery. The year has as many ways of dying as men have. Here the year's death is a red one. Caught by the first chill of winter in the full foliage of summer, the leaves, 
instead of shrivelling and dropping one by one in a sobbing November wind, burst into a crimson glory, more beautiful in death than they were in spring-time. There are no colours on the artist's palette in which to paint the autumn foliage on the Hope Mountains; no words in the AngloSaxon language in which to describe them. The crimson of port wine against the light ; the glow of sunlit windows by Albert Diirer ; the red glow of embers in a frosty night_all these pale beside the burning October bushes on the mountain-side, lit by a late September sun, and vividly contrasted with the sombre pines and gray ruins with which they are surrounded. Of all these bushes the brightest is the crimson sumach, but maple and dog-wood and a score of others display the purest, most transparent tints of every hue, from golden green to royal purple. Summer dies here with a smile, under clear skies which seem to bring heaven very near, and then a wild wind sweeps off the leaves at a coup, the snow falls thick and heavy, covering all with its beautiful white wreaths, and the year is dead, by a beautiful 'sudden death,' dead before it has got old and feeble, sere and yellow, and the onlookers are spared the dull yellow fogs, and the agony of tears through which an English summer lingers to its grave. Dreaming of these things, and pray- 
ing, perhaps unconsciously, that you may die the death of the Canadian summer, while the blood is still hot in your veins, with no long sick-bed prelude, you have unconsciously got far ahead of your train, though your pace has been the natural walk of your pony. The bells are out of earshot, and you rein up and wait on a little bare patch by the river's bank. A quarter of an hour passes by and you are tired of noting the old camping-ground on which a generation of packers has made its dampers, drawn the water for its tea, and contentedly eaten its beans and bacon; tired of scrutinizing the bear-tracks in the river-bed, and frustrating your pony's attempts to roll, when suddenly a storm of oaths and a furious clattering of hoofs bursts on your astonished ear, and the lean figure of old S., in his shirt-sleeves, not smoking, dashes through the pines in pursuit of that etc., etc.'d Buckskin, who appears to be proceeding entirely on his forefeet like a performing dog. Between us, S. and myself stop the buckskin. S. has him by the head. I clear out. How the old man holds on I can't conceive. Long habit has something to do with it. No one but a packer could live with that cayouse five minutes. I can find no corner safe from his heels. The brute appears in danger of parting at his girths, so madly does he lash out. At 
last old S. is off his legs, and here comes Buckskin, his nose on the ground, and his heels like twin comets flashing furiously all over the place. How we ever stopped the brute I forget, but when we did he had utterly worn himself out as well as S. and myself, while his load was scattered in quiet corners, down steep banks, and in thick bushes along the trail for a mile and a half from the point at which he stood shaking all over, the sweat running off him, and his two captors too dead beat to swear.

Whilst we wearily hunted for the wreckage of what had once been a neat pack, the sun began to sink behind the ridge, and when old $\mathrm{S}$. had given the last vicious tug to the diamond hitch which bound the pack again to the saddle, seven miles lay between us and our camp, and barely an hour of daylight remained. And all this because the smell of the fresh bear-skin had been a little too much for the pony's nerves. Nor was the weary ride in the dusk the end of our trouble. Though we camped in the dark we had failed to make our point, and the place at which we set up our tent was a bare patch amid the pines, a long way above the level of the river, amongst the great boulders of which the hapless beasts had to be turned out to look for their supper. At all times a bad camp, it was 
now (late in the season) worse than ever. Not a blade of any green thing, not a root of any hard scrubby weed offered even a bite sufficient to tempt a goat or a jackass, and it was with much misgiving that we set up logs and brush to bar as far as possible the escape of our pack animals from the cheerless quarters to which we were obliged to consign them. Then ensued a bad half-hour in which three men expended much patience and many lucifers in hopeless search for a dry tree to chop down, a kettle to get water in, or a level place to pitch the tent on. It is poor fun camping after dark on an old much-used site, where all the dry wood has been used, and we found it so. No one seemed sorry when the chattering of the robber-birds made us open our eyes to the pale pinks and blues of an early morning sky, and the necessity of hunting 'them horses.'

After an hour's absence the old man came back without them, croaking dismally. 'They had gone back to Hope, and we would have to follow them, or on to the bunch-grass of the Ashinola, and then they were as good as lost to us,' he guessed ; but then we did not guess: we knew by this time that our old friend was no Mark Tapley, so we left him to chop wood while Charlie and I tracked the truants. And a rare 
chase we had, along that bare river-bed, through woodfalls and thick scrub, always thinking we heard the bell just ahead of us, only to find that it was nothing more than the tinkling of a brook amongst the stones which had misled us. The sun was a good half-way up the heavens before Charlie's quick eyes descried the wanderers, standing stock-still amongst gray logs and boulders, looking sullenly in our direction, wornout, poor beasts! in a night-long search for supper. It was no easy work getting the horses out of the maze of fallen timber in which they had involved themselves; but if you give him time an unloaded cayouse will scramble over anything, and once on the level track I drove them home at a run which left the young half-breed panting half a mile behind. That day we wound slowly up and up by endless zigzags to the highest point of the ridge, and had the infinite pleasure of seeing the hills begin to fall away, until we could almost fancy we looked down upon a level sea of prairie and the broad, sparkling waters of the Similkameen. But that was still a long day's journey off, a day during which the trail wound through wide park-like lands, clothed with excellent grass, and thickly studded with handsome groups of bull-pine, while huge log fences suggested here and there that wild though the 
country looked, wandering members of the great Anglo-Saxon family had nevertheless, even here, marked out what they were pleased to call their property with bounds and limits. Now and again we came upon great corrals of high-piled logs, and once upon a log-hut, of the roughest and most primitive fashion, but labelled, none the less, Similkameen Hotel. True, no one was in, and the door was locked; but three pairs of antlers, amongst the pressed meat-tins and other rubbish round the hut, showed by their freshness that someone had been there very recently. A more perfect country for deer to winter in I never saw, with ample food in the sun-dried grasses, and shelter in the deep hollows, and amongst the clumps of great trees. And its looks do not belie it, for the man who lives at the closed hotel, of which I just spoke, met me afterwards, and told me that last winter he shot ninety-four deer himself, though he did not reckon himself much of a shot (and he was right there), and did not trouble after them much. 'What did you do with them?' I asked. 'Well, I eat some little, and fed my hogs on the rest!' From the crest of the ridge to the Ashinola the horses were in clover, and soon became something better than mere anatomical studies. On the summit we found good feed, deep, rich grasses, 
and a strong heathery growth, through which dark burns crept slowly. Here, hot and weary, I threw myself down, gave my mare, Dolly. Buckskin, her head, and watched the jolly little beast revel in the sweet grasses. Poor dumb pack-horses! how we cursed them in the morning! but whowould not wander if sent supperless to bed? Like the horses, we were beginning to tire of the rations of the road, beans and bacon and damper, and to speculate on what good things we should find at Alison's store on the Similkameen.

As we jogged sleepily along about mid-day a distant roaring far up the glens caught my ear from time to time and puzzled me. Gradually the sounds got clearer, and I recognised the lowing of cattle. Shuttleworth, too, heard it, and came galloping to the front. 'That's E.'s cattle coming, squire; we shall have to clear off the track and keep quiet.' Nearer and nearer came the beasts, while we sat still and silent in a clump of trees well off the track. Everything on this trail must give way to the cattle. Byand-by a bearded man in his shirt-sleeves came along on a good-looking nag, closely followed by two or three beasts, while little groups of three and four forced their way, lowing and playing through the bush by the side of the trail. The man kept speaking from time to time to the 
beasts as if encouraging and reassuring them by the sound of his voice. By-and-by he sighted our party, and recognising S., asked him to give some message for him at Alison's. The unfortunate S. seized the opportunity to ask if one of the drovers could take our bearskin back to Hope, and was promptly overwhelmed by a flow of strong language, rich and varied in quality, for his folly, as if the beasts knew his infernal voice! Did he want to scare the whole band back to the Ashinola? So difficult is it to get these beasts to 'drive' quietly through this timbered country that everyone has to treat them with as much consideration as if they were royal personages, instead of good-looking beasts with a good deal of Hereford and shorthorn blood in them, being driven by their owner (a man worth several thousands a year) to Hope for shipment to market. Ten to twelve miles a day is all the cattle will do; the distance they come is about 100 miles, and a drive of this kind has to be made from the ranche in question once a fortnight all through sunmer. So that ranching is not all beer and skittles. The cattle and the pack-trains in the early fall use the trail so much that you rarely see game en route, even if your bell is not going, but at other times deer are plentiful enough. 
Packing is one of the principal trades in these remote districts, and many men, whites as well as redskins, live by it in the summer months, carrying provisions for the winter and stock-intrade to the different ranches and stores up country. On our road we met pack-trains of all sorts, mules and greasers, a redskin chief and his cayouses, and even a train of Chinese Johnnies in sky-blue combinations and pig-tails. It is a lazy life, suited to the redskin and the Mexican, who begin the day with an hour's work hard enough to be pleasant in the cool of the morning, lashing on the multitudinous packages. As each beast is fixed, and his head-rope neatly coiled and fastened, he gets a gentle kick in the barrel as a hint to clear out, and moves off for a quiet browse until the rest are ready. By-andby the last is 'fixed,' and then for an hour the pack-train moves lazily along, the men shouting from time to time and smoking incessantly. At the end of an hour the horses' barrels have grown a trifle smaller, and in spite of all the hauling at the ropes in the morning, some of the packs have shifted a bit. So a halt is called, and the backsliders among the packs readjusted, the train starts again, and probably gets through its day's journey of ten miles without further interruption. At four the train stops, the packs are taken off, 
the horses turned loose to look after themselves, the men begin baking and frying their bacon, and at dark the camp is asleep. For this work packers get nothing when going out 'light,' and, at present rates, three cents a pound and 'grub themselves' when loaded. The distances covered vary from 100 to 150 miles, and they will pack anything, from flour to furniture. Mule-trains belonging to Mexican greasers do about ten or twelve miles a day, while Indians and their ponies do nearly double. A horse's load is from 200 to $300 \mathrm{lbs}$, and as a rule two men and a cook with twenty horses compose the 'outfit.' Late in the afternoon we came upon another class of workers, sitting beside the trail where it ran close to the river's edge, through a deep sandy soil. A group, these, of quiet, inoffensive-looking little fellows in blue, with rather ragged-looking pigtails, eating their wretched daily ration of rice under a lean-to shelter of bark. All about them were little holes and pits in the sand, as if they had meditated burrowing away from the rough white men who revile and molest them. On being civilly addressed in pigeon English by my guide, they huddled together like sheep, and though they smiled upon us benignly, refused to enter into conversation. Perhaps they could not understand S.'s pigeon English. I confess I 
could not. 'Washing for gold, that's their little game, and they thought you wanted to collect the tax ; that's why they would not talk,' said S. ; adding, "if we had been after the tax, we would soon have got them to tip up, though.' 'How so, S.?' 'Why, squire, we should have just taken the biggest Johnny and tied him up by his pig-tail to a bough of the handiest tree, and the gold would have come out before his hair did.' Hard this, I thought, on the ingenuous Johnny ; but S. had been a local policeman, and knew John Chinaman well, and told me that some of the most cruel murders he had ever heard of had been committed by Celestials. What had S. not been-this gray old man, with good manners and universal knowledge, who quoted 'Horace' correctly, quoted, too, from the Greek Testament, wrote distinctly passable verses for local newspapers, was well up in military history, and cooked my bacon and beans as well as he talked Thompson River Indian, or Similkameen? I used to sit over the camp fire and wonder at the old man's memory, as he talked of what he had learnt at 'the shop' in the days before he got his commission as a ' gunner,' before, too, he lost all he was worth, and more, on the racecourse, and came out here to marry a Thompson River Indian woman, rear a dusky brood, drive a pack- 
train, or run through the long months of winter on snow-shoes through the wildest districts as Government postman. I suppose some of my readers will throw up their hands and pity this man, who might have done what the world calls well in the old country; and the only parson I met who knew him spoke slightingly of the old man because he lived with and kept to the squaw whose children were his children. Those who feel sorry for him may spare their pity, and the parson remember that a marriage may be an honestly performed contract, though not sanctioned in his little church; for old S. is as jolly as a sandboy, would not go back to civilization if he could, and as he has just had a little money left him, will probably end his days in all the comfort he cares for, in a snug ranche up country. Sober as a man need be, kindly and honest, old $\mathrm{S}$. is a gentleman all over, and though sometimes a trifle slow and very despondent, so that he and I quarrelled hotly at times, a kinder fellow never handled an axe or smoked a quarter of a pound of tobacco daily.

As you near the Similkameen River the miles vary in a way perplexing to the last degree. One mile ridden dreamily at a foot's pace is got over in thirteen minutes; the next, over equally good ground, ridden also at a walk, takes half an 
hour. The fact is that the surveyor has not got as far as this along the trail, and the mile-marks have been the result of extremely casual guesswork among the natives. But at last a broad blue river between bold mud-bluffs smiles up at you as you ride through the bull-pines of the last upland, and in another half-hour the river is forded, and we are at Alison's, a large single house, built by the pioneers who dwell in it, fenced about with rough snake-fences, and surrounded by three or four little log-cabins, in which Chinamen or Indians dwell. Alison's is a good sample of a pioneer's home, the centre of a large but thinly peopled district. Upon the bluff opposite you can just see a few yards of snake-fencing. If you rode up to it, and then followed it round, you would find I don't know how many miles of it enclosing thousands of acres of grazing-land, the pioneer's principal wealth. By-and-by that may be as valuable as land at home; at present it is only good to graze the bands of cayouses which belong to the station. The house itself is mostly devoted to the purposes of a store, in which the boys or their mother will serve you or the Indians with sugar, blankets, or anything else you want. Outside, at the moment at which our train comes up, three of the boys (one about eighteen, 
and the others little fellows ten years younger, I should think) are busy roofing a log-hut with shingles, and doing their work smartly and well. When they have made the hut weather-proof, it is to be used as a school-house, and someone (I did not clearly gather who) was pledged to send them a schoolmaster now and again to teach the station children to read and write. That bit of a boy, who looks hardly old enough for trousers, will, when our horses are unloaded, catch and saddle a pony for himself out of the band in the corral, and then drive our beasts off to the meadow for the night, and bring them in again next morning. What with taking care of the store, fencing fresh lands, breaking horses, building, etc., there is always plenty to do in the summer for all of them; and in the winter there are deer to be shot, and the young ones at least while away the long evenings with story-telling, the mother collecting the wild fairy legends of the Indians, and dressing them in familiar language for her children. The Indians themselves are excellent story-tellers; one old fellow whom I met at Alison's telling me a bear-story with such vivid pantomime, that though 'kheelounha' (grizzly) was the only word of his language which I knew, I had no difficulty in following him. Bear-stories were rather the fashion in 
the Similkameen district when I was there last year, two Indians having been killed in the neighbourhood by grizzlies within the month. There was near Alison's one noted bear-hunter, whom I was very anxious to obtain as a guide, but unfortunately he was away. This man had lost two brothers, killed by bears, and pursued a regular vendetta against the whole family of grizzly in consequence. It is not every Indian hunter who hunts bears, and those who do make a business of it, and they only, have any idea where to look for bruin, who is about as difficult to find, except by chance, as any beast of the chase I know. After all, old S.'s bear-story was the best I heard; I don't vouch for its truth. Let the responsibility rest on the old man's shoulders. He and (let us say) Seth Davis were packing together in spring through the Hope mountains. It was very early morning, and the horses had strayed. Seth and the old man were out looking for them. The horses they had lost were eleven in number, and by-and-by Seth made them out in the gray dawn; feeding on the slope of a hill half a mile away. To get to this the two men had to cross a cañon and scramble up a very steep bank immediately overlooking the place where the horses were feeding. Very much out of breath and out of temper, the two 
scrambled up the bank, and Seth looked over. Only for a moment, though; then with a serious white face he turned and whispered to the old man: 'S., we don't want them horses!' 'Don't want 'em! Why, aren't they ours?' 'No,' said Seth, 'I guess they aren't our horses; they're bars, blarst 'em ! grizzly bars ; let's git!' And the two old packers 'got' in a peculiarly rapid and stealthy manner as far as possible from the family party of eleven grizzlies, which Seth had mistaken for the pack animals.

At Alison's the first real difficulty met me; all the Indians were either away 'packing,' or at a potlatch. (i.e., tribal 'drunk'), and no guides seemed likely to be forthcoming, unless it might be a certain Tintinamous Whisht, a gentleman of whom old S. had a very poor opinion. However, I was not to be daunted; if the worst came to the worst, I thought I could do without an Indian, and the sight of a splendid mule-deer's head, killed last 'snow' by Edie Alison, encouraged me to proceed. The head referred to spanned 2 feet $4 \frac{1}{4}$ inches, inside measurement, and numbered twenty-six good points.

On the day on which I reached Alison's we made a capital drive of 27 miles, and though hoarse and tired from the part I had taken in the day's proceedings, I was well satisfied when 
we unsaddled at the 'Nine Mile Creek'-where an Irishman and his half-breed wife dispense hospitality to the pack animals, at the somewhat exorbitant charge of 50 cents apiece for a graze, or 1 dollar apiece for a feed. However, it was no good grumbling, so we paid the money, or rather gave a cheque for it upon Wardle's, and then got the woman to cook us some supper. I think I never came across a more miserable little home; the scenery stern, the place remote, our hostess sulky and forbidding; the only servant the most abjectly melancholy of Chinamen, who lived in a ruinous wet old tent at the back of the house, where were two bald, lonely, unkemptlooking patches of ground set round with white boulders, within which last year were buried the woman's first family — her husband and little child. The second husband of this lady landowner is indeed a daring son of old Erin, and I wish him luck. What astonishes the traveller here is, that neither white nor Indian seems to do any cultivation. All the labour is spent on fencing, and when that is accomplished nothing more seems to be attempted, so that really all the settlers rely upon are these rough pastures for their cattle and horses. Once only I came across a potato patch ; and when, later on, the Admiral's party arrived, I heard of an energetic ranche- 
owner whose home was supplied with vegetables of his own growing, and apples which California could not beat.

And now my six-days' travel drew to an end, and the valley of the Ashinola came in sight. Two villages, named in recognition of their industrial achievements the Potato Ranches, were passed, with their heavy log-huts all empty, all shut, glaring at the passers-by through little new glass windows, which looked oddly out of place in these wilds. Once we passed a graveyard, surrounded with new wooden palisades, and dominated by a tall cross of rough-hewn wood, which looked as earnest and real as the piety of the Catholic fathers who give their lives and wear out their educated minds in teaching these remote tribes of redskins.

Once, too, we passed another tomb of another kind, a simple white tent, with the door open and a flag flying, in which some chief was camping, waiting until nature and the elements of air and water should resolve his body again into the dust from which he came.

Over long stretches of arid steppe-like land we passed, on which land-turtles and porcupines and a few grouse are found, and on which I discovered, to my sorrow, that a peculiarly thorny species of cactus grows abundantly. These pests are about 
as large as pigeons' eggs, and grow in clumps, which, being of the same colour as the ground, are invisible. One of old S.'s jokes for many a day, I doubt not, will be to describe how 'the Squire,' as he used to call me, stepped on his first cactus, and then, holding the injured moccasin in the air for him to extract the thorny trouble, plumped inadvertently down upon anything but a bed of roses. To have what I once heard the present Home Secretary describe, in the Nisi Prius Court at Birmingham, as 'that cushion which kindly Nature has provided for tired humanity.' converted, at a moment's notice, into a 'pin-cushion,' is a little more than any man born of woman can endure in silence; and I fear the more S. laughed the more I ejaculated, and deeper and deeper the iron entered into my soul. When at last we camped at the forks of the river, the sky was full of rain; clouds were round the peaks ; no Indians were said to be in the village; it was only by digging out a site for our bed, inches deep in the soil, that we could escape the ubiquitous cactus; and altogether the barometer of man and nature was decidedly 'stormy.'

Thine,

C. P. W. 
LETTER VI.

Dear Pat,

Camp of the Winds.

When I finished my last letter, we were all sitting miserably disconsolate in Cactus Camp, the heavy rain-clouds threatening to drown us, and no news of a guide for the morrow.. The only Indian in the village was sitting in his miserable hut watching his little daughter die, because there was no medical aid in reach, and his small stock of remedies had long since failed before the dread disease of which she lay dying. While the stars were still in the sky, old S. saddled his horse and rode away; and at about nine he came riding back, with a quaint little figure on a flea-bitten gray by his side. In another minute the first gleam of returning sunlight entered the camp along with my trusty 'gunner' and his captive, the typical Indian, whose name was 'Tommy'-Toma, his friends and relations call him-and if he is not a chief, he 
is the brother-in-law of one; but as you contemplate the little fellow in his blue canvas shirt, penny straw hat, and gray Yankee trousers frayed into a fringe round the ankles of his moccasins-as you look at his brown dog-like eyes and merry Mongolian little face, you forget the chieftain, and instinctively christen him 'Tommy.' Tommy was to me a revelation. Anything less like Fenimore Cooper's dignified savage I have never seen. From his dry, withered and hairless features he might have been any age; from the eager animation of his manner he might have been sixteen or a Frenchman. The Ashinola tongue lends itself naturally to acting. When Tommy began to talk, his voice was somewhere far away down in the blue-shirt region; by-and-by it ascended, and his utterance grew rapid, his words short and close-clipped until he came to a very big superlative, and then his eyes grew wide, and he lingered whole seconds over the word, like an Australian doing a ' cooey.' Unfortunately for me, his noble relative, 'Ashinola John,' had told him that the Englishman was in straits, and that he could charge accordingly. As I liked the look of the fellow, I yielded in part to his extortions, and in an hour's time we had cached our superfluous baggage, and were on the way to the sheep-grounds. Where we cached our goods 
was by the main highway of the district, and 'cached' by no means expresses what we did with them, for there was no attempt at concealment, the things merely being put up in trees to be more or less out of the way of vermin. And yet the untutored redskin and low-class Mexican 'greaser' will leave them untouched, though he needs them more than the tramp who would certainly remove them if left by an English roadside. The highest trial of honesty $I$ ever saw out West was on my way back from the Ashinola. A bar (of timber) crossed the main trail near an empty corral. Anyone coming along the trail must stop and dismount to remove the bar, and, doing so, come face to face with a small glass bottle, labelled ' best French brandy,' and apparently full of that excellent cordial. It had obviously been put there for someone expected shortly on the trail, and as the thermometer was very low and the sleet very bitter, I confess I had to look very earnestly in another direction to avoid the temptation offered by that neat little flask of bright amber fluid.

Whilst Tommy made his final preparations, I got old S. to supply me with a dozen or so of the most useful words in my hunter's dialect, which I proceeded to study. In cruising about the world after big game, you acquire the most 
wonderfully polyglot vocabulary of hunting terms, which at critical moments are apt to get mixed. The patois of Switzerland, Little Russian, Lesghin Tartar, German, Georgian, French, Chinook, I have had to converse in all in turn; but $I$ find that in emergencies I always revert to Russian, and for a moment feel dazed at the Indians' stupidity in not understanding me.

At about 9.30 we took to the hills, electing the right-hand side of the valley as we were informed that Tintinamous Whisht knew the other side best, and meant to take the Admiral's party in there. Though first on the ground, I hardly thought it fair to take my pick, as the other party had already made their arrangements ; and perhaps I may here be allowed to say that I think it would be an excellent thing if there were some code of rules for the conduct of men who shoot big game all over the world, as binding amongst Englishmen and gentlemen as the rules which govern the actions of the same class in India. There I believe I am right in saying that no man would dream of intruding on the valley occupied by another party without obtaining permission from the first-comers. Of course, where there are no such rules, "Devil take the hindmost!' becomes everyone's motto, and operates injuriously to all. 
We had hardly cleared the first low benches of beautiful golden grass, when we sighted four bighorn, low down on the hills across the river, feeding, indeed, just along the top of the little moraines which formed the very foot of the hill-face.

Tommy and I at once left S. and the boy to signal to us any change in the bighorns' position, and then scrambled down and forded the river again, under cover of a small thicket of trees, amongst which Tommy left his steeple-crowned hat and most of his clothes, whilst I left all I could spare. The climb up the moraine was very good training for what was to come in the next three weeks, and seemed to impress my guide favourably as to my powers of silent progression; but, of course, when we had skirted innumerable moraines, we found the sheep had gone, and on signalling only discovered that our ' flag-waggers' had gone placidly to sleep. The spot on which we left them was both mossy and sunny.

For the rest of the day we rode or led our animals from one 'bench' to another, scrambling up stony little ravines and long slopes of slippery grass, and anon diving into thinly-timbered hollows or basins, in which everything-shelter, the finest of grass, and water-combined to make a very paradise for game. As yet there were not many tracks in these hollows and on the beautiful 
yellow grass slopes; but Toma told me that when the snows of November have driven deer and sheep from the heights, these lower ranges are alive with game. Towards noon rain began to fall, mixed at times with little 'flurries' of snow driven by a bitter north-easter, so that when Toma suddenly dropped out of his saddle, and slithered downhill on his hams, although I followed him with all promptitude, I felt far too frozen to find my trigger, and was not in the least surprised at a couple of misses right and left at sheep at about 300 yards. Toma wiped the snow off the seat of his trousers with a sigh, but said nothing, and I confess to a feeling of depression as I watched all those juicy mutton chops careering away downhill. Everyone seemed a little sad about it; even old S. d-d his son, and his son took it out in d-_ing the unhappy horses. Whilst so amused they unfortunately ran into a little band of mule-deer, and sent our haunch of venison 'in posse' galloping after our chops. We camped that night by a tiny grove of hemlocks at the head of a little bay amongst the hills, in which some execrable bird, described by the Indian as between a hawk and an owl, was screeching aloud for rain. The snow lay here and there in little drifts, and two or three great blue grouse, frightened by us or dis- 
lodged by the wind, whirled from tree to tree as we came up. It was a miserable night, with the eternal beans and bacon only to console us for the chances we had missed, while the wind roared amongst the hemlocks, and, when the darkness set in, tore long streamers of fire from the logs, carrying flames and heat away together into the darkness. A whole tree seemed to burn out in no time, and the even chop-chop of the axe seemed likely to last all night. The bitterness of that night was worthy of an English May. The wind cut through flannel waistcoat and chamois vest, through four ' four-point blankets' and other odds and ends as if they had been muslin. The snow and sleet and darkness had it all their own way, and the wind almost blew our fire bodily away; and yet through it all, there sat Tommy outside the tents, with his socks and moccasins in his hands, warming his bare toes before the fire, not even condescending to put on the ragged old overcoat which he had carried behind his saddle all day. From time to time he gave a little cough, or pretended to button his buttonless canvas shirt round his neck; and when in pity I offered him a tin pannikin of whisky and hot tea to warm him he seemed quite hurt, and assured me that 'he didn't care to eat after meals.' Whether that meant that I ought to 
have offered him the whisky sooner I didn't know (or care), so I swallowed it myself, and turned in on great boughs, which the 'boy' had found less trouble to provide than the proper 'brush,' and which very soon found out every soft spot on my hide, and made to themselves others where none previously existed.

I soon discovered next morning why Tintinamous Whisht was a 'bad Indian.' All night long Tommy had been chopping logs and making up the fire; when I woke he was cooking, and was wanted to find the horses, whilst the 'boy' and his father did the 'superintending' part of the game. This, I suppose, is the natural instinct of the white, to make his darker brother do the work; but a little animated conversation between $\mathrm{S}$. and myself set matters straight and put Toma in good temper again. If you would have success in your shooting and no squabbles in camp, make this a rule of the chase : keep your hunter for hunting only, and let your other men fully understand that he is not the 'odd man' to do everyone's bidding. A first-rate man, if he is benighted with you, will work for your comfort like a slave, but considers all work except hunting beneath his dignity on ordinary occasions.

Yours,

C. P. W. 


\section{LETTER VII.}

My learned Friend,

Bighorn Camp.

Day after day to follow the deer in any weather, no matter what winds buffet you, so that they blow pure and full of health from heaven and the hill-tops, is the keenest physical enjoyment I have ever tasted; but you might find it far from enjoyable to follow my wanderings day by day on paper, so I will skim the cream of my three weeks for you, and present my experiences in small doses.

The camp which we made our headquarters was far above the hemlock-grove, at the very head of a little gully, running up to a stern crest of rock, which looked almost like an extinct volcano. Our tents were pitched on opposite sides of the great fire, and surrounded by a thick clump of small pines, from which the gray squirrels hung head downwards all day long, vituperating us with the energy and endurance 
of an American alarum. Down below the knoll on which our tents stood ran a tiny brook, from which we drew our water-supplies; and on the far side of it was a great grassy bluff, running up to the volcano, along the sharp edge of which we often saw, in the early gray of morning, deer and sheep outlined against the sky. Down the stream on either side were patches of pine-trees and a little dead forest full of fallen timber, which seemed the most favoured haunt of mule-deer in the whole neighbourhood. In camp were strewn on the ground or hung on the trees half a dozen noble rams' heads, decayed and weather-beaten, but suggestive trophies, nevertheless, of the sport the redskins had enjoyed last fall. All round and below us were great rolling yellow sheep-downs, cut up by gullies and cañons, but covered everywhere with beautiful sun-dried hay.

These downs stretched right up to the foot of the bare crags which formed the crest of the ridge, ran out in some directions in a succession of benches until they rolled right down to the river below, but, on the other side, came to an abrupt end at the edge of steep and precipitous black rocks, sparsely covered with sweet-smelling juniper-bushes, and here and there in less steep places with larger trees. The favourite haunt of the sheep seemed to be on the very edge of these 
downs above the cliffs, to which they betook themselves at the least symptom of danger, setting the stones rattling down in volleys as they scampered headlong over places which looked hardly safe for a man without a rope.

On my first day I think I drained the cup of disappointment to the very dregs, and as my fortune has mended steadily ever since, I cannot help feeling that Ill-luck on that day spent her malice upon me. We had hardly left camp, when we made out on the downs below us four muledeer lying with their heads uphill. At first, to me, they looked only like great gray rocks, but when (having turned our horses loose) we had gone a mile or so, and Toma invited me to peer over a little knoll, I saw through the tall bents the great erect ears of three hinds and the spreading antlers of a buck, not sixty yards from me. Slowly the hinds rose, one by one -not winding us, but restless and suspicious. Then at last the buck rose, too, and I knew to a hair's breadth where the bullet should strike him. But the hammer fell with a sharp click; and no report followed. The deer, only half startled, trotted away for fifty yards and then stood again. Trying to keep my temper, I fired as steadily as before, and again the confounded rifle played me false, and either the deer 
saw me as I pushed the useless weapon from me, or heard the second click and were frightened, for away they went at best speed, the first barrel of my spare rifle missing fire like its fellow.

Toma spoke English then for the first and only time I ever heard him, although I believe my old guide was right in saying that he understood and could speak it a little if he chose. 'Gun no good ; haiyu no good,' he muttered, and I agreed even with the quaint superlative ' haiyu' (anglicè, 'very ').

However, the morning was early still, and we could now see little groups of hinds sauntering off towards the timber in several directions, so that we did not despair of adding fresh meat to our menu of bacon and beans before dinner-time. Our next stalk that morning was for better game than deer-to wit, for two grand old mountainrams, which we had made out with my glasses, lying down in a sunny little corrie, very sheltered from the wind, no doubt, and comfortable, but dangerously easy to approach. When at last I raised myself and looked over the ridge, the first bighorn I had ever been near was certainly not forty yards from me, standing up and looking away from me over the recumbent form of his fellow. Two splendid beasts they were, with finely-curled, heavy horns, and coats so dark that 
with dew and sunshine on them they looked almost purple. And again my express, which had served me so well with only two miss-fires before that morning in ten years' work, missed fire, and set the bighorns going best pace downhill. As they went, I snatched the spare rifle from Toma, a common Winchester repeater, and knocked over the hindmost ram at the gallop. Unfortunately I hit him too far back, so that he recovered himself, and, as the hillside was bare and stony, my hunter could not track hin except by the blood, which soon ceased. Let me have done with the story of that good rifle's delinquencies at once. Sometimes it went off, oftener it would not, until, at last, I lost confidence in it to such an extent that $I$ missed even if the rifle did not miss fire. The last evil turn it did me was one morning on the broken face of the cliffs. We had both rifles with us, but when Toma whispered 'Bears,' I forgave my old friend, and put my trust in her again. Two black bears, huge big fellows, with glossy black coats, were scuttling up the bank through the yellow birches, their fat sides shaking as they ran. Both barrels missed fire again, and by the time I had got hold of the Winchester the bears had disappeared.

From that date, though the Winchester had lost its back-sight, I used it exclusively, and 
learnt to like it (though it only cost 40 dollars) as well as my high-priced express. The worst of a repeater is, that there is always such a temptation to (as the Yankees say) 'pump in lead as long as you can see the durned critter.' This seems to me an argument against the adoption of repeaters by our troops. They will certainly cost us a great deal in ammunition, and lead to loose shooting. But a Winchester well handled is an accurate little weapon; and I met a gentleman this year out West, who really could knock the heads off at least four grouse out of six, at from twenty to fifty yards with his repeater, and not ruffle a feather below the neck. That first day in the hills was a Saturday, and it had certainly been a 'dies iræ.' On the Sunday following I gave men and horses a rest, as I always like to do, and looked forward keenly to the morrow's hunt on the ridge above. Unfortunately, towards noon rifle-shots began to re-echo about the hills, and down below on the next 'bench' we could see some horses picketed, and the blue smoke curling from some other fellow's camp-fire. Then there was sorrow in Bighorn Camp, and S., lighting his twenty-seventh pipe that day, got on his old cayouse, and went down to spy out the land and see what manner of men these might be. 


\section{LETTER VIII.}

\section{Dear Pat,}

Bighorn Camp.

Six thousand miles by road and rail and ocean steamers, added to six days through mountain forests, in which even mining engineers and Indians are scarce, should suffice even in these miserable days of over-population and over-civilization to ensure the traveller solitude which the ring of no other man's rifle should break. And yet on my second day in camp there were white men's horses down below on the next ' bench' of grass, and white men's rifles were making the cliffs rattle above my eyry. As my old hunter came back without any very definite report, I rode down on the Monday evening to interview the enemy in person, my heart swelling with a just wrath. As I rode down the brae, I was aware of a person beyond the brook, who, with his back turned, appeared to be deep in some culinary operation. I did not know then, but I 
have discovered since, that he was making 'parritch.' I believe he must have come from far Dundee for the sole purpose of making porridge, as only a Scotchman could under any circumstances. Certainly, if he will forgive me for saying so, I don't think he was much enamoured of big game shooting. His friend was coming down the opposite bank at the moment, leading a tired horse-a horse, I should say, very justly tired with carrying the fourteen stone of young bone and muscle which walked beside it and tried to disguise its nationality in a cowboy's hat and shirt. Reader, have you seen two bull terriers with their backs up, their tails high in air, walk round and round each other with the angry sniff which being translated means, 'Now then, who's going to begin'?

If one is very much bigger than the other, they probably fight. If they are a really good match, they probably trot off amicably together and find a little dog to worry. We trotted off together. My new friends had not come in from the same side of the country as myself, and when they camped were absolutely ignorant of my presence, but with a courtesy beyond all praise offered at once to clear out, if I claimed a prior right to the ground, and considered there was not room for three rifles at the same time. 
Naturally, we tossed as to whether they should dine with me or I with them, and agreed to draw for choice of beats day by day.

That night old S. and 'the boy' were in great form. The Scotchmen had only got Indians to look after them; the old gunner would show them how things were done in a white man's camp.

Charlie (the boy) had had a successful day's sport amongst the rabbits and grouse, our neighbours, who shared the little clump of trees in which we lived. Like the son of Jesse, he used only pebbles from the brook; but the stupid jack rabbits which he tracked in the snow sat still until he hit them; and the 'fool hens,' as they call the big grouse here, are more stupid than the rabbits. I well remember one fool hen, who stolidly sat out a bombardment of at least half an hour, on one of the top branches of a pine, until Mr. W., my Indian, and myself had used up all the stones we could find in a radius of 200 yards. We hit her twice before the Indian brought her down, but though the bough on which she sat was struck scores of times, she would not fly. On another occasion, I remember pursuing one of these birds amongst the pinewoods with a stick When I threw it she flew, and of course I missed; but at last she allowed 
me to knock her down with a good straight cut. These grouse are the most preternaturally stupid animals I ever saw, but cooked they are excellent. A dinner at Bighorn Camp, Ashinola, is not a very ceremonious affair. My guests rode up at seven, and my men spread the seat of honour (a red blanket) on the windward side of the fire, under the lea of the tent. The Indians sat opposite. I think they rather enjoy the pungent smoke of a wood-fire. Outside, the dark pines sheltered us from the wind, with whose voice a wolf's howl was blended from time to time, as a whiff of the savoury roast reached his nostrils. Within the charmed circle of the firelight, all was bright and cheery. Two old whisky-cases, which held our stores, served for tables. The billies and rifle-barrels gave back the gleams of the blazing logs, while the bright red blankets inside my tent made a bright and cosy 'interior.'

And so we sang our songs, smoked our pipes, and pledged one another in libations of whisky and tea, while the men indulged in the luxuries of 'packers' jam' (i.e., brown sugar and bacon-fat), ribs roasted in the embers, and cigarettes of chopped 'pigtail' and newspaper.

That night we parted in good fellowship, and promised, as our guests prepared to face the perils of a homeward journey by as rough a road as 
'diners-out' ever trod, to join camps on the morrow on the lower ground.

This arrangement worked admirably, and whilst W. and myself shot to our hearts' content, $\mathrm{H}$. thoroughly mastered the art of porridge-making. But things were going too well to last. On Sunday we all lay on our oars and planned a great expedition for the morrow, or smoked and threw each other's boots at the great black-capped robber-birds, who not only stole the mutton hanging on the trees round the camp, but actually came and stole from our very plates. About mid-day we sat up as if galvanized, and made the same remark in chorus. It was not quite a welcome, I fear, though the cause of it was the advent of another Englishman, the forerunner of a part of the Admiral's party, under the leadership of a Canadian gentleman named C. To be just, the new-comer was ready to go at once and give place to the first settlers; but the gentleman who belonged to the country, Mr. C., had other views. $\mathrm{He}$ asked us to come in and have a pipe ' next door' after dinner; next door being where he had camped about fifty yards from us. We went. He was a jolly good fellow, and the naval whisky was excellent; but as for making room for anybody on earth, our new friend declared it might be all right in the old country, 
but it would not do here. "Where were we going to shoot next day?' Thinking at least he would, if we told him, avoid our beat, I suggested the top ground. 'Ah! that's just where we are going;' and C.'s face simply rippled with laughter. If anyone ever enjoyed 'pulling another man's leg,' C. enjoyed that luxury on the first night we met. My Scotch friends smoked in silence. There appeared to be no precedents for a case of this kind, and no one could quarrel with a man so full of innocent mirth, and absolutely unconscious of the enormity of his offence.

'Look here!' suggested C. ; 'I've promised these gentlemen that they shall get sheep, and they shall. What do you say to our making a drive all together? You have not done much good so far, and if the sheep are there, as you say they are; we are bound to get some, if we send our Indians round to drive.' I did not like the idea, but it was the only thing to do ; so I consented, fully determined that after the drive the great gathering of sportsmen at Bighorn Camp should be less by one. Of that drive I'll tell you in my next letter, if I ever survive to write another; and I candidly confess that the idea of all these riflemen together, round the topmost crag, with a frightened ram dodging from one to the other, is to my mind suggestive of more risk 
to the hunters than to the ram. The camp altogether is sad to-night. My young Scotch friend W. met a small band of the big black wolves which have been molesting our horses lately, and unfortunately found them, as some men find the rabbits at home, quite a foot too short for shooting. So he is sad over misused opportunities, while I sadly think of the morrow. The laugh is on the other side our camp fire tonight.

Yours gloomily,

C. P. W. 


\section{LETTER IX.}

\section{Dear Pat,}

Bighorn Camp.

We had not been very successful until the arrival of Mr. C.'s party; in that C. was perfectly well informed. The Scotchmen had, I think, got one small sheep and a hind for meat, whilst I had secured two stags, two small rams, and a very fine old ewe, with horns almost as big as a young ram's.

But we had been learning our ground, and were very bitter at being robbed of our reward. There was not a ragged cliff whose face W. and myself had not climbed, scrambling over moraines, up dizzy little sheep-paths, on inclines which tried the wind and wore out moccasins and indiarubber soles at the rate of three pairs a week, and all only to discover that the chief asylum of the sheep was in the crags at the top, from which, when disturbed, they descended and scattered through the lower cañons and through the 
timber. For the last four days we had gradually been working the sheep back to the heights, and now others were going to reap the reward of our toil. However, it could not be helped, so at about 7 a.m. we mustered in force. The command of the expedition was offered to me, but was declined on the score that I did not know anything of sheep-driving. So C. sent out his men, and he and I rode off together.

'Now, my dear fellow, I don't care for a shot; I've shot scores of sheep; if we see any, you take the first crack at them,' said my companion; and my heart went out to him for his self-denial. I had left Polly, my buckskin mare, in camp, as she was a bit stale from over-work, and had taken out instead a big, rather well-bred looking screw, bought by old $\mathrm{S}$. at the Alison ranch for 20 dollars. The screw moved under me with a fine free stride, which is wofully wanting in the native cayouse, and I really thought if there was any galloping to be done that day, my horse was the horse to do it. Captain S. and the rest of the guns took the right-hand side of the crags ; C. and myself went down wind to the left. At the very outset Captain S., who was a little in advance of his party, came face to face with a splendid mule-deer buck, which, from the reports of those who saw him, I take to have been bigger 
than my big buck or any killed during the expedition. The foolish beast stood broadside on at fifty paces, and with a rare self-denial, worthy of a good sportsman, Captain S. let him go without firing at him, rather than risk disturbing the nobler game we were in search of. Now, looking back, I can only regret that the buck's head was not added to my friend's trophies, for immediately afterwards C. and I sighted a band of small ewes on the bare slopes to the left of the 'crater.' To my surprise C. at once began to ride hard. To my remark that there were no good heads amongst them, I got no answer ; and as C.'s object was evident, I joined in the chase, determined that if the law of the day was to be 'Shoot at everything, and devil take the hindmost,' I would do my best not to occupy that invidious position. Alas! as the horses faced the incline, I felt my screw's powers fade away, until the swinging stride slackened to a walk, and a hideous roaring informed me that my poor beast was broken-winded. So C. got in first; the foolish ewes, getting thoroughly confused and standing in a bunch, huddled together as stupidly as if they had been domestic Shropshire downs, whilst ' the native' dismounted and 'pumped lead into them' at about 100 yards' range. When I came up he had secured three, 
and was having them gralloched. I should have felt happier if the Indian had killed them before he and his master began gralloching. As no amount of philosophy could make a man on a broken-winded horse genial under such circumstances as these, I fear poor C. found my congratulations somewhat wanting in warmth, and, to my delight, betook himself to the top ground, he and his Indian riding away in full view along the ridge. However, the rifles now were ringing out in all directions, and as I had kept Toma with me, I felt there was still a chance of getting a shot at some beast which my friends might miss. The top ground at the crater is a succession of little circular hollows, filled up in places with large round ponds; here and there are stunted forests, or rather spinnies, of pines, contorted and dwarfed by cold and the barrenness of the soil in which they grow. Here once Toma and I had watched a wolverine, apparently hunting in the snow; and though the sly beast, the trapper's worst enemy, is rarely seen in broad daylight, we let him go. Here, too, we stalked and spared the biggest mule-deer buck I ever saw, principally because, in spite of his size, he carried no antlers.

But now the rattle of rifles was echoing amongst these mountain sanctuaries, and we down below 
amongst the cliffs watched the gullies eagerly for anything which might attempt to descend and seek shelter in the forest of pines beyond. Now and again we saw some one ride along the skyline at the top, and once I tried two long shots at a couple of rams working their way down wind along the cliff-face. This turned them, and sent them over the top, where I believe they passed Captain S. at a fairly long range, and at a good pace. But S. had taken up a position where he was out of sight, and kept cool and quiet, biding his time, so that when the leading ram passed him he turned him over with perhaps the best shot fired that day. At last my turn came. There was a rattle of stones in one of the main gullies leading from the crater, and five old rams came galloping down for the forest. They were making so much noise themselves that it mattered little that my Indian and I bumped and slipped about, now on our feet, now on our backs, in our frantic endeavours to get to a point from which they must pass within range of us. At last they saw us, threw up their noble heads, planted their fore-feet with an impatient stamp, and stood at gaze. It was only for a moment, and my hand rattled on the stones as I rested my rifle for the shot; but every bullet has its course fore-ordained, so in spite of my shaking aim, the leading ram fell 
over with a crash as I fired, and another fell in his tracks as they dashed away in headlong flight. It was a weary while before Toma and I overhauled even my first ram, and he took three more shots to finish him and bring him to bay; but I was as thoroughly beaten by the chase over the cliffs as if I had run a three-mile race; my knees began to fail me, and the perspiration (lean though I was) blinded me. As for the other ram, though the blood-track was plain enough at first, I was too tired to follow, but gave Toma the rifle, and lying down on a point from which I felt too weak to descend in safety, left him to find and finish the beast for me. However, I think Toma was very nearly blown; at any rate, my second ram was never found, and I had to be content with the first, whose measurements were 14 inches round the butt and $28 \frac{1}{2}$ inches in length round the outside curve of the horns. Both horns were a little broken at the points. Though only a seven-year-old ram, and though a good head, it was neither unusually large nor symmetrical. The total bag that day was three sheep and three rams, the latter killed, one by Captain S., one by my Scotch friend Mr. W., and one by myself.

That night there was much rejoicing in camp; trifling disagreements were forgotten; it was 
conceded that C.'s plan had at any rate the merit of success, and, however angry one might feel with him when he crossed you on the hillside, it was impossible to resist his cheery goodfellowship when the day was over. Still, my next letter will not be from Bighorn Camp.

Yours truly,

C. P. W. 


\section{LETTER X.}

Dear Pat,

The Dead Forest.

Practically this letter was written in the dead-wood forest at the top of the downs, where all the little rills which water the camps and run down to swell the volume of the Similkameen have their origin in a bleak, swampy moss. Fire has, at some time, swept through the forest, and left the dead trees standing grim and gray, flakes of dark moss draping them in very funereal fashion, so that one involuntarily feels chilled, and wishes that Nature would be considerate and bury her dead, replacing the gaunt trunks with younger trees and greener. In this forest I lay, note-book in hand, stretched along a smooth fallen trunk about which the sunlight played, writing my record of the week, while Toma tried in vain to track a dying buck which we had seen fall twice before he entered the timber. As I lay there unmoving, two great ravens came from 
some peak above, and lighting on dead trees hard by, discussed in harsh, angry notes what manner of thing I might be. 'Dead! is he dead?' they kept questioning; but though they came sailing down very near, they could not quite make up their minds. Brutes! I should like to have resolved their doubts with a bullet. Still lying there, I heard the leaves move, and looking down a vista amongst the pines $\mathrm{I}$ saw two great-eared hinds looking at me. I should think they stood for full ten minutes-it seemed hours to me, my muscles ached so with the effort to remain absolutely quiet. Presently they were satisfied, and walked daintily out of sight, followed immediately by a handsome buck, tossing his branching antlers as if he had led the van and dared the risk, instead of sending his meek mates in front to see if all was safe for him. I had killed as fine, if not a finer stag of his race. The sunlight was very sweet, and I enjoyed the silence, so, though my hand crept towards my rifle, I let him go unhurt. This forest seems full of mule-deer. In the morning all the highest of the downs are alive with them, in big bands; but that is only whilst the light is still gray and the day young. As soon as it is broad daylight they all vanish, creeping away into dark moss-carpeted woods, still and damp, in which your foot sinks ankle- 
deep, without a sound. Next to that prince of deer, the 'wapiti,' the mule-deer is the biggest of his family in America-as big, I should say, almost as an ordinary Scotch red-deer. $\mathrm{He}$ is a handsome beast, with a face boldly blazed with patches of black and white upon russet-brown or gray. His ears are the most noticeable things about him. I have just measured the ears on the head of a buck shot by me, and I find that from the root to the tip they measure ten inches. This is almost as long as the animal's face, from a point between the horns to the tip of his muzzle.

The biggest buck which I have had the good fortune to secure has a span of nearly two feet from antler to antler, ten large well-developed points, and a heavy beam five and a half inches in circumference. This is, of course, not an exceptionally good head; but I think it is above the average of the mule-deer on the Similkameen. We had known this stag for a week before we got him, his favourite haunt being just below our camp, amongst some fallen timber, in which it was almost an impossibility to approach him unheard. Three or four times, when creeping over the logs, we saw a pair of great ears listening on another bank, then half a dozen hinds would trot quickly through the timber, followed by this 
lordly beast, so heavy with good feeding that we wondered to see him clear the great logs in his way. Once, when stalking a band of bighorn rams, he rose quietly from his lair in front of us, and we could see his fat sides shake as he trotted away. But he did not disturb the rams, so we let him go. At last his time came. Meat was wanted in camp, and we were going to shoot a distant hill-top. When the even chop, chop of the old man's axe awoke me, the country was wrapped in a gray, smoky mist which hung about all day, and the trees were silvered with frost. S. was working hard, but complaining bitterly, according to his wont, as he explained to the boy that the stars had left the sky, and the boss would soon want his breakfast. Then there was a short mental struggle with the desire to remain curled up in one's blankets, whilst the growing fire warmed and lit the inside of the tent-a struggle soon over, and followed by an heroic wash almost deserving of the dignity of a 'tub.' The bottle of sweet-oil for the rifles which stood by my bedside had frozen hard in the night, and a pack of wolves, whose howlings we had heard, had stampeded our horses. By the tracks they must have driven the poor beasts almost through the camp-fire, whither they had come for succour ; but the night was too dark for the Indian to see 
either wolves or horses when the noise woke him, and the fire had almost died out. Since the wolves, there had been another visitor in camp, a lynx, whose tracks came almost up to the tents. We arranged a trap for him, and then went out to look for our horses. Having found them none the worse for their scare, Toma and I saddled our 'hunters' and rode off over the downs, on which the snow lay in considerable patches. There was nothing I feared so much in my Similkameen experiences as these early morning rides with the frost on the grass, and many a mile I tramped rather than ride over the break-neck slopes, covered with long slippery herbage, on which even the Indian's gray could never keep its footing. We used to progress in a succession of slides and slitherings, and it required experience to enable you to trust to your cayouse's recovering his footing when you felt that he had three legs in the air and the other was slipping. On foot and in moccasins, I could not keep my feet without a stick, and yet, after a week's practice, Dolly and I would join Toma and the gray in a break-neck canter merely to warm our blood.

On this particular morning, on the next bluff to our own, we sighted the big buck and six hinds leisurely feeding back to cover. The cover 
was half a mile away, and the deer, having seen us, moved off towards it at a smart trot. Toma made signs to me to follow him, and next moment we were over the ridge out of sight of our quarry, and galloping 'ventre à terre' over a horribly slippery slope, in the endeavour to cut the buck off before he could reach the wood. As we came over the ridge we saw we were just too late, his stern disappearing amongst the timber as we came in sight. The snow was falling, and as we hardly anticipated work so near camp, I still wore a macintosh; my feet were, as usual, in moccasins. Without a word, Toma rode full gallop into the timber, threw himself from his horse and dashed downhill over logs whose sharp and ragged limbs caught and tore my flying macintosh, and over stakes and flints which almost made me howl as I trod upon them. But in spite of all we held on at best pace for half a mile, and then we caught sight of the buck, rather blown with his recent exertions, lazily lurching over the fallen timber, while the hinds were far on ahead. It was a fluky shot I fired, for I was at least as blown as the buck, though in better condition; but it brought him up all standing for a moment, and gave me a chance of rolling him head over heels with the second barrel before he had recovered from his surprise. I never saw a fatter 
beast in my life, and my little redskin was enthusiastic over the piles of white fat which he collected from the entrails and back of my first mule-deer. To the Indians this fat for winter use is the most valuable part of the game. When we brought his head into camp, old S. recognised him as the buck which he had met, face to face 'at fifty yards, sir, close to camp, just whenever I didn't happen to have anything but the axe handy.' Since shooting the big buck, I have killed others, and might have killed many, a day never passing without, at least, one shot at a mule-deer buck presenting itself unsought; but I contented myself with the three best heads I saw, shooting two of them 'on the jump' in thick timber, of which they are far too fond to make them ever unpleasantly popular with the orthodox deer-stalker.

If others visit these shooting-grounds, or any other deer-frequented ranges near Indian villages, it would be kind to deal death sparingly among these creatures which supply the native with food and foot-gear, and afford him, now that he may neither scalp nor steal horses, the only amusement which makes his too civilized life worth living. Even now, in this glorious climate, Pat, I cannot help feeling that if I were free to choose I'd 
rather wear a scalp-lock than a wig, rather steal horses than prosecute others for stealing them, rather be a barbarian than a barrister.

Yours truly,

C. P. W. 


\section{LETTER XI.}

'The Sheep-trimmed Downs.'

My sympathetic Friend,

You will easily understand that after the drive stalking was a thing hardly worth considering. The rams might be anywhere, but were less likely to be in the open country than anywhere else. The Indians always have stories of inaccessible crags to which the wily bighorn retires in times of persecution, but I have never yet been able to find these fastnesses, though I have always made a point of getting to the top of any country in which I happened to be camped. They talk, too, of the old beasts with the mythical heads, measuring eighteen or twenty inches round the butt, and curling twice against the brow, dwelling in some remote peaks, and only coming down in the rutting season to woo and make war, or in the depth of winter, when all the heights are buried in snow, and even a mountain sheep cannot live far above the level 
of the prairie. It may be that the big rams retire to the more remote ranges, to which even the Indians do not know the way, or to which, if they do, they will not guide a stranger; but for the most part, where disturbed, I think the rams hide in the timber or in the precipitous cañons below the feeding-grounds. Here it is a hopeless task to seek them, and a mere fluke if you succeed in finding them. My Scotch friends had gone the day after the drive, and I lay at my pony's feet with my boy Toma looking across the sea of peaks, with which we were almost on a level. I never met the man yet who was so good a fellow that I would not rather have his room than his company in a shooting-camp. At any rate, if two are company, more than two are too many. I confess this is an unlovely trait in my character, but it is there ; and as I looked over the waves of purple peaks, crowned with masses of ragged black cloud, and lit here and there by a ray of autumn sunlight, I sighed for solitude. As I looked, the sun touched a great rounded shoulder of the mountain far away at the back of the first range beyond the river, a shoulder bare of pine woods, far above the timber, and in the sunlight looking smooth and golden with rich dry grasses.

' Toma, do you see that peak, beyond where 
the Admiral is shooting on the other side, beyond where Mr. C.' (another solitaire) ' has his camp, right back amongst the mountains ?'

'Nàwitka, yes,' replied the boy, stopping in his occupation of adorning his old straw hat with the feathers of grouse and a stray eagle's feather he had found.

'Well ; did you ever shoot there?'

'No ; never.'

'Could you find your way there?'

'No ; I don't think so.'

Toma evidently did not want to go.

'Well, Toma,' I concluded, in a tone of decision, ' come along back to camp to get ready ; we will go down to the river to-night and camp there; to-morrow we will try to get to that shoulder.'

That night we camped by the river, wherein, to my utter surprise, bitterly cold though it was, my little Indian bathed bodily. Of course I followed so good an example; and caught a nice basket of trout afterwards, with a hazel pole for a rod. I could see a big spotted fellow lying in the clear still water behind a great boulder, and tried to tempt him with a wonderful scarlet worm of india-rubber, which I bought long ago, and have carried unused for many a year. The ridiculous thing nearly gave that trout a fit, and 
a subsequent offer of raw venison failed to console him. So, in spite of the unfitness of my hazel wand for such work, I had to try and throw a fly. Flop it came on the water, and the trout almost bolted again. But the second time he stayed to look at this new lure, and, like many a more civilized fish, he found its charms irresistible. So we added a dish of trout that night to the luxurious dinner of grouse and venison and hot cake, which already awaited us ; and next morning, 'bright and early,' as the Yankees say, we struck camp, and began our climb towards our new shooting-ground. We had not gone half a mile before I found that, though it had not been used that year, there was a trail to my peak, and this was not the first time that Toma had travelled it. Indeed, after a time, he confessed that he had hunted there before, ten years ago, but that the road was very bad for horses, and there were not many sheep there. It certainly was a villainous road, and so steep that it had, almost all of it, to be done on foot. Even 'the boy,' who used to anger me beyond endurance by the stubborn laziness with which he stuck to his poor devil of a pony in any circumstances, rather than use his own legs, had, on this occasion, to get off and walk. It almost consoled me for my own weariness to see, for the first time, my cook 
tramping like his master. The difficulty of the trail sufficiently accounted for the rarity of the natives' visits to this particular peak, as my experience of the Ashinola Indian is, that where he cannot hunt on horseback he does not care to hunt at all. The noble savage can do as much hard work as anyone, but will avoid it always if he can. By noon we had scrambled up the last step in the ladder which led to my land of promise, and my moccasins were hanging about my feet in rags, so that I had to rely on old S.'s good nature, who gave me his last pair, and submitted for the rest of our trip to the misery of wearing a good-looking pair of knee-boots, of which he was inordinately proud at starting.

As we dragged our horses after us up the last moraine, from which we looked on the downs beyond, Toma sank with a low whistle to the ground. Lying there behind him, we rested, and watched six splendid rams feed slowly to the top of the ridge and disappear. Then we hurried on through a piece of 'brulé' to where, above a patch of boggy gray moss, in which a little water stood in pools, a patch of burnt timber afforded just sufficient shelter to hide our tents from the game on the great bare snow-patched sheep-walk above. The camp was the bleakest I ever looked upon, but we left old $\mathrm{S}$. to do his 
best for us, hobbled and turned the horses loose, and then climbed the slope of red-gold grass on foot, going down wind until we crossed the saddle, and then turning up along the upper edge of the timber, where the grass began and the trees ceased. Here was the very home and haunt of the mountain sheep. Thick pine-forests stretched away below us, growing thinner as they neared the downs. Along the boundary-line between the two were rocky moss-covered ledges, overgrown with a strong heather-like plant. On these ledges, and amongst this heathery growth, we found scores of warm, wind-proof lairs or forms in which the sheep had been wont to take their siestas. Here, too, we found a rusty huntingknife which some former visitor had dropped. Not five minutes before, Toma had been regretting that he had left his knife behind. Now his face beamed as he put the rusted blade through his belt. 'I thought,' said the superstitious little fellow, 'that crackling in the fire this morning meant a roast; now' (tapping the knife) 'I know.' Here a crashing of boughs interrupted us, and crouching down, we peered through the scattered pines into the green darkness beyond, where, after a moment, we caught the quick flicker of gray bodies passing through the: timber. 'Only mowitz' (deer), muttered 
Toma, rising and going on. The noise in the timber had drawn my companion's keen eyes downhill, so that it was lucky that I was not trusting to him entirely, or I should not have caught a glimpse of two great white sterns on a little plateau above us before it was too late. To clutch the little fellow in front of me by the waist-belt and drag blue shirt and tall grass-hat unceremoniously in a heap to the ground was the work of instinct.

To the indignant protest of his face, two fingers held up, and the whispered words, 'Sheep, hyas sheep, selokwha hyas!' (Very, very big ones) was sufficient answer, and next moment you could see the very soles of his moccasins trembling with excitement as he lay peering through the heather at the six rams we had seen earlier in the morning, feeding now in happy ignorance of their danger.

Toma is a splendid little Indian, not one of your lazy red-skinned louts who care only for the dollars and the 'broil' in the embers when the day's work is done, but a keen little sportsman, eager for blood as a terrier, and full of sympathy for another's keenness. But this time I meant to do the whole thing myself. I had found the rams, and I meant to stalk them and kill them in my own way, or lose them altogether. So I 
persuaded Toma to lie down while I crept and crawled slowly, yard by yard, over the terribly bare ground between me and them. Once I lay down to rest, and, looking back, I could see the little chap, his keen face strained my way, like a hound held in leash when he winds the deer. Such stalks as these, such beating of heart and bating of breath, take a week out of a man's life in five minutes perhaps; but what gambler's excitement could equal them? At last I reached a fringe of heather, and allowed myself the first glance at my game since I had caught that momentary glimpse of them before I pulled down my guide. There they were, six of them, all good rams, some feeding, some with their heads up, and, furthest from me of all, the master of the band, his feet planted on a little butte 150 yards away, looking fixedly in my direction, his beautiful dark face and snow-white muzzle, his curling horns and broad chest, standing out bravely against the sky. The others were all nearer, all easier shots, but I never saw so graceful a head before as 'the master's;' and as I pushed the rifle slowly through the grass, I swore to have him or none. Bravo! as the smoke curled up, he pitched forward on his head, and springing to my feet as his mates rushed by, I rolled over another good ram, who, however, 
picked himself up, and with the rest dived down below the crest of the bluff. The shots could not have taken more than a few moments, but as the smoke of the second shot still clung to the Winchester's muzzle, Toma snatched it from my hand and dashed off in pursuit. It was good going over the down, but I could no more catch Toma than he could catch my wounded ram. This was unlucky, for as I stood to breathe on the top of the cliff I saw the five pass in single file across the face of it, about 150 feet below me. Had I had my rifle I could have secured my wounded beast and another. As it was, I watched them out of sight, and then went to look for my Indian. Bits of him strewed the hillside - here a coat, there a straw hat. By-and-by I came upon him; with his head tied up in a handkerchief, gazing down into a deep horseshoeshaped cañon, of which the crags on which we were formed a side. All round the cliffs rose sheer and high, and right at the bottom was a tiny prairie, through which a considerable stream ran, rising in a small, brightly blue lake, gleaming like a turquoise from among the burnt timber. As we gazed we heard at intervals a dull hollow shock echo up the gorge. ' Rams fighting,' whispered Toma, and directed my gaze to the bottom of the cañon, where, by the brook, stood ten rams 
in a circle, their heads all turned inwards, while from time to time two of them rushed together, and caused the sound we heard, horn shocking heavily against horn. We watched them for some time, and then followed my wounded ram, which we found on the face of the cliffs, spent and dying. My bullet, meant as a coup de grâce, brought him to life again, but after a blind charge downhill he lay apparently dead about 200 yards below me. On getting down to him he rose again and went off best pace downhill, with me after him, until he suddenly dropped clean out of sight, and by throwing myself flat upon my back I just saved myself from following him over a precipice quite high enough to have finished my career.

Having scalped him, Toma and I went back to our first 'kill,' which we found where I fired at him, covered already with a gray frost, and looking as big as a pony on the hillside. My bullet had caught him full in the middle of the chest, and he had dropped dead at once, with a head of something like white clover still held in the side of his mouth, as a groom holds a straw. I measured him as he lay, and found him from the root of the tail to the nape of the neck 3 feet 6 inches, while his girth was 3 feet 9 inches, and his approximate height at the shoulder 3 feet 
2 inches. The bighorns of the Cascades appear to me to differ in one point somewhat from the bighorn of Montana, these latter having their horns curled closer, and lying much flatter against their heads than is the fashion with their Cascade cousins.

That night was a night of fête in my lonely camp, and 'the gunner' made what he called a ' north-west fire,' on which whole trees lay and flared out in the mountain-wind; but when morning broke the fire was hidden in snow; what Toma called 'smoke' wrapped everything in its heavy folds, so that nothing was visible to us fifty yards from our tents; the little pinetrees were bowed down with the weight of the snowflakes; two of our pack-animals could not be found, and when we lit our camp-fire again, the rest of the poor beasts came and stood round it, with their heads down and their tails to the wind. All day the air was thick with winter's swarming white bees, and all day we sat cowering idly in our wet snow-piled tents. Poor Toma looked so pitiable in his one blue canvas shirt that I had to give him one of my own flannel garments, whose somewhat gaudy colouring had won his simple heart.

One more backward glance at the best sheepcountry I ever saw, and I will smother my sighs 
and set my head for Temple, E.C., the shadowy side of my life.

It is the morning after the snow, and as bright as yesterday it was dim. The two lost packhorses have been found, and already my redskin and $I$ are half-way up the bluff above the peat bog. Looking down at our little gray tents among the bare burnt pine-poles, we give an involuntary shudder, and wonder how we ever lived out yesterday's storm. Looking up, our eyes are dazzled with the sun's laugh upon the snow, with the glitter and the flashing of the millions of diamonds on the great white cone above us, up which we creep ever so slowly. When we reach the top we see how local the snowstorm has been. Round us all is white, but away to the west, line upon line the blue ridges run, without a flake of snow upon them. From the nearest a great feather of mist floats out into the clear sky, like the smoke from some mighty fire. All else is clear and sharply outlined. On the sunny side the ridge we feel there is no time so good for man as a winter morning, but cross the top and leave the sunlight, and you will see Winter without his smile. The diamonds are all dead, their lights gone out; no colour glows in the gray air; Nature is without life-blood, cold, bitter, unbeautiful. Even in the sun that day 
we had to turn down the ear-flaps of our shootingeaps, and Toma showed that he felt the bitter wind by tying a fag-end of rope tighter and tighter round the waist of his old coat. The snow was cut up in all directions by the wandering sheep and deer, but somehow we missed them on that last day, though once I stood within 200 yards of a band of rams, standing in serried rank, heads all level and still as stones, staring at me; but I did not see them in time, and when Toma's frantic gesticulations called my attention to them, they vanished into the timber, on the edge of which they were standing, before I could fire. I killed a big buck for his antlers and his haunch, in a glade of the forest, fairy-like in its snow-draped beauty; and then we struck the tents, and carrying our trophies with us, sought the low country again. My head is now turned for home, but, as you may well guess, I shall dwell as much as may be on the journey. If I get any more sport you shall hear of it.

$$
\begin{aligned}
& \text { Yours truly, } \\
& \text { C. P. W. }
\end{aligned}
$$




\section{LETTER XII.}

Mr dear Pat,

The Potato Ranche.

There are two beasts in America which are not of to-day, whose forms have nothing homely about them, who dwell in such wild solitudes and are so weirdly monstrous in their outlines that they seem to be the births of fairyland, or, at least, the last relics of an earlier creation, when herds of gigantic mammoths pastured on the desolate tundras of Siberia, and the elephant and the cave-dweller lived at Maidenhead. I mean, of course, the moose, which wanders along Canada's chain of lakes from the Arctic to the St. Lawrence, and that quaint white beast, between a poodle and a buffalo, which haunts some few remote mountain-tops in the north-west, and to which naturalists (recently introduced to it) have given the high-sounding title of ' haploceros montana,'

English sportsmen call it the Rocky Mountain 
goat; natives in the Cascades call it "the white sheep ; naturalists, out of pure perversity, I suppose, call it an antelope, the antelope being the lightest and most graceful, while the 'haploceros' is the heaviest of beasts; and after all, it looks much more like a little white buffalo, only clumsier, with its back rising in a heavy hump, and its shaggy white beard and coat, the latter hanging in wide frills to its ankles. The horns are bent back slightly, and are about twice as heavy as a chamois', but not hooked like that little beast's. The horns on my best goat's head (which I think a very good one) are between five and a half and six inches in circumference at the base, and the longest of them is nearly nine and a half inches in length. Behind each horn is a black leathery orifice like a false ear, and in this I found a deposit like musk, and certainly as strong in scent. Each orifice contained about as much of this deposit as would equal a small bean in size. Is this useless, or might it not be a substitute for the precious little pod extracted from the musk-deer of India?

An excellent photograph of the beast, from a negative, I believe, in the possession of $\mathrm{Mr}$. Baillie Grohman (who has been almost a godfather to this goat, if not its actual discoverer), has long lain in my portfolio, and now, having 
seen a good deal of the original, I can commend it as being a wonderfully faithful portrait.

On my way back from the sheep-grounds, I camped one night on an old Indian campingground in a narrow valley over which tall hills and mountain-peaks impended. The Indians had left for the moment, but their traces were round us on all sides, in the bare poles which once supported their tents, and on which now, in trustful fashion, were hung little bags of deer's hide, containing Heaven knows what. Paint, perhaps, to adorn themselves, or the dried galls of beasts to use as drugs. A few frying-pans, too (with holes in them), lay around, and innumerable feet of deer, showing plainly on what the tribe had lived. A stream which ran through the camp had been dammed, hardly as neatly as if beavers had been the engineers, and there were traces of a native laundry and bathing-house. Small beds of dry brush showed where each chief had lain, and by the bank of the river at some distance was a low mud hovel, in shape like a bee-hive, with a hole facing the water just big enough for a man to crawl through. This, my guide told me, was an Indian 'sweat-house' (the word sounds ill, but it is good English), a native form of the institution known in different countries as Turkish or Russian baths. Like the Russians, the Indians are 
in the habit of rushing from their frying-pan into the cold water or snow outside, hence the invariable position of these huts on the river-banks. The Indians on the Ashinola, at any rate, are a cleanly people, especially on their hunting expeditions, before starting upon which they indulge in most wholesale ablutions, and during which they are rude enough to insist upon the ladies of their party sleeping in little wigwams or shelters by themselves. But I am off the line. White goats, not redskins, should be the subjects of this letter, and it was because a colony of white goats was said to dwell in these peaks that we camped at this particular spot; an old Indian campingground on ordinary occasions being a thing rather to avoid than to seek. The goat is very local in its distribution, and keeps a good deal apart from all other beasts, living in the most barren mountain-tops, where, though it finds something to browse upon, no grass tempts sheep or deer to share its solitude.

Its skin only sells for $\$ 1.50$ at the Hudson Bay agencies in the North-West, and its flesh is so unappetizing that even an Ashinola Indian won't eat it. So when three or four years ago (and Toma was sure it was not longer than that) two white goats appeared from no one knew where, on the sheer cliff opposite, no great 
efforts were made to kill them. In that neighbourhood the animal had never been seen before. The oldest inhabitant had never heard of a goat on these hunting-grounds, and though in the second year a few were killed by the young braves out of curiosity, and as a lesson in natural history, after that no one meddled with them, the braves not caring about goat's-flesh, and, unlike the braves of the civilized world, being quite content with the 'scent' with which Nature had endowed them. So the goats increased and multiplied, and when I pitched my tent at the potato ranch on the evening of October 18th or 19th (I forget which), I was assured that the hill behind me was full of bearded billies and their dames. It was starlight when we rose next morning, and as we sat by the camp-fire breakfasting and watching the light of a new day spread over the precipitous face of rock opposite to us, Toma and myself exclaimed simultaneously in various languages: 'By Jove, there is one!' and when the glasses were brought to bear, we found that not one but three of the beasts we sought were slowly browsing across what looked to us a sheer wall of rock. Old S. was for immediate pursuit. Toma and I dissented, long. experience having taught us both that when you can see a beast from your camp-fire, the odds are 
that that beast has seen your camp, and will be peculiarly wide awake all day. So we finished our breakfast and rode our long-suffering ponies along the first bluffs which led up to the heights on which we expected to find our game. But even these first bluffs were so steep that the ponies lowered their wise heaảs to inspect every stone on which they trod, and even then slipped so badly on the steep sidling hill, that for fear lest we should be precipitated horse and man into the foaming mountain-torrent, whose course the yellow aspens marked below, we very soon picketed our steeds and walked. 'Lunch, tyee?' questioned Toma ; but the 'tyee' (i.e., chief) did not like the look of the steep sugar-loaf above him, and wisely decided to put the lunch in his pocket to be eaten (if at all) at the top. Thighdeep we waded through the swirling waters of the burn, and then began to work our way in a steep zigzag uphill. Toma was in splendid form, and his pace undeniable. I knew I had only this one day left to kill my goat in, so that I dare not remonstrate; but I prayed earnestly that Toma might slip or drop something, if only to gain a moment's breathing-space. Thrice only the little man paused in that heart-breaking climb, and then it was on some vantage-point from which he expected an extended view of the 
sides of our hill or its neighbours. He might look for goats; I did not want to see any. With a sigh I sank at his feet the moment he paused, larding the lean earth with a torrent of heavy drops from my brow. Perhaps each pause lasted three minutes, and then at it we went again, as if we were climbing some corkscrew whose end was beyond the clouds. At the third pause Toma's face lit up, and four fingers held aloft gave me the first hint of the presence of a like number of goats still some distance above them.

By-and-by Toma took me by the arm, and pointed to the very highest ledge of the rocks which crowned our hill, whereon, with his family between him and the approaching danger, lay ' a big man-sheep' fast asleep. Then all fatigue was forgotten, and fear-fear lest we should be unable to come within shot-took its place. To avoid the she-goats, we were obliged to descend a little and then come up the opposite side, and so over the crest to our quarry. Even with the hill between us we had to walk warily, and this on those perpendicular slopes added greatly to our difficulties. All the timber round us (of which there was a good deal) had been burnt in comparatively recent times, and the sharp-pointed pine-boughs barred our path or caught in our clothes and stayed our progress. If we laid a hand on them 
to move them from our way, they were so brittle that they snapped with a report which sounded to us loud enough to rouse Rip van Winkle from his hundred years of slumber. Then there were the fool-hens. When we wanted one for the pot, there was always a difficulty in finding it; but when found it would sit immovable, whilst every stone in the country was hurled at it. Now there seemed to be a fool-hen in every tree, and though we crept past them like shadows, the great birds would whirl out of the pines as noisily as a rising covey at home. It seemed as if we never could reach the top undiscovered, when a low ' hist!' from Toma turned me into stone. Not thirty yards in front of me was a grayish mass, hard to distinguish clearly, for running right across it was the stem of a fallen pine from behind which this strange figure had risen. I could see the horns and the great hump, could just make out the quarters, and under the $\log I$ could see the beast's legs, but I could see no vital spot to fire at. For a couple of minutes we stood equally immovable, the goat and I, and then, slowly raising my rifle, I waited. My movement stirred him, and for a moment I got an indifferent glimpse of his shoulder, and, as I supposed, planted the bullet in the right place. At any rate, he fell to the shot, though he picked 
himself up again and scrambled off through the timber, never showing me again enough to fire at. Hurrying breathlessly after hirn, we almost ran into him in the next 200 yards, and this time, as I had a clear view of his shaggy bulk, I dropped him, dead beyond all doubt. To our surprise, we found this was not my wounded goat, but another; so, leaving him, we climbed on up to the crest, looking over which we found the first great ' man-sheep,' as Toma called him, whose siesta we watched from below, stretching himself and listening as if uncertain whence the sound of my shots had come. He was a magnificently white and bearded patriarch, and I was sufficiently annoyed when he rose after my first shot and went off along the cliff's face as if nothing had happened. And now followed a strange chase. The goat was on a narrow ledge and going leisurely. I could not get to him unseen, and would not give him up. My only chance was to follow him on to the ledge, where, if he looked back, he must see me. For some time he did not look back, but sauntered along not a bit lame, but quite unconcerned. I could have shot him at any moment, but not so as to kill him neatly, his ragged quarters being all I could see of him. I was beginning to dislike the line of country which seemed to him sufficiently easy for a wounded 
goat, and in my struggles to keep my feet some pebbles rolled more noisily than usual down the ravine. This attracted his attention, and he turned his head over his shoulder and stared at me stolidly for quite half a minute, wondering apparently what I was and what on earth I wanted, but not afraid. After looking long enough to begin to get eerie notions into my head, I managed to get a steady shot at this uncanny white beast, who was certainly not forty yards from me all the time; and a bullet not far from the root of his ear sent him toppling into a land where all doubts cease.

I could have bagged more goats had I wanted to, as there were at least a dozen of them, male and female, about the craggy point on which we were, and every ledge had been their lair at some time or another; but I was sick of the stupid brutes, and satisfied with two great graybeards I had already bagged. My first goat, hit, I fancy, too far back, betook himself to a place to die, where I could not follow, though Toma promised himself his skin, after he should have left my service on the morrow. I don't know whether he ever got the skin, but I fancy not, as my little friend got a scare that day which will keep him from those mountains for some time. $\mathrm{He}$ had left his knife in camp, so that he and my 
half-breed cook had to return again that night to skin the two he-goats I had bagged. As they skinned the last and largest, they had to turn him over on his other side, when, dead though he was-he bleated! Toma was nearly beside himself with fright, and the half-breed had to finish the skinning, Toma declaring that it was an omen, and portended all manner of grisly terrors in the near future. Poor little Toma! I hope the storm of misfortune passed you by as scatheless as it passed me, and that by this time you believe that it was only the wind escaping from the dead beast, and not a spirit voice, which you heard.

That night Toma lay by the fire, for the first time dead beat. My last pair of tennis-shoes were soleless, my last moccasins in shreds, and when I suggested 'Just one day more in the hills,' Toma shook his head, saying, ' No ! Indian tired; Indian can't go any more; must go home and rest.' Au revoir, Pat.

Thine, C. P, W. 


\section{LETTER XIII.}

Dear Pat,

Hope, B.C.

The Rocky Mountain goats of the potato ranch afforded me my last day's sport in the Similkameen country, for though I tried exceedingly hard to secure a guide to the haunts of those grizzlies who were reputed to dwell on ' the summit,' I failed in my endeavour, partly because most of the best men were away 'packing' or 'trapping,' and partly because all the native hunters of the district were suffering from the effects of a scare caused by the death of a Hope Indian, killed outright by one of these brutes, and the death of another Indian near Penticton, who had been disembowelled and left by a bear which he had found feeding upon the carcass of a deer shot in the early morning. The poor fellow lingered for three or four days, but succumbed eventually to his wounds, and the grizzly, though badly wounded, managed to escape 
the party of revenge which pursued him. At the Alison ranch no hunters could be found, so that I had to be content with my single interview with old Ephraim, and determined, if possible, to get to Hope in time to catch the boat for Westminster. That sounds rather homely, does it not? and brings the embankment and muddy Father Thames vividly before the mind's eye; but the road from Princetown to Hope is not quite so easy to travel as that from the Temple to Westminster, and I was assured that if I compassed the distance in two days, it would be as much as I could possibly do, even without pack-horses. We camped one night at 'the summit,' i.e., at the top of the ridge which shuts off the Similkameen country from Hope and the Fraser. Here every year Winter sets up his first blockade, and already the first snow had fallen, and the little burn was hard frozen, when at 4 a.m. I went to it for my morning tub. At breakfast we had a guest, a white man whom we passed the night before driving a couple of draught oxen slowly over the mountains. $\mathrm{He}$ was a strange instance of the waifs and strays you meet out West. Apparently a fairly welleducated man of thirty-five or so, he had gone in to the Similkameen country in the harvest-time with a well-bred American horse, which he had 
bought at some point far east of Hope. The horse (a stallion) had been his stock-in-trade, and with him he had tramped hundreds of miles by mountain trails, forcing his way, self-reliant and alone, into all sorts of remote corners in which white settlers had taken up patches of prairie land. Finally, he had disposed of his horse at a good price, made some money in the harvestfields, invested part of it in the handsome pair of oxen he was driving when we met him, and was now on his way to some point at which he expected to dispose of them at a profit. What he made by his year's work could not have amounted to very much, but it was an independent wandering life, and that seemed to satisfy him.

In my two visits to the American continent, I have met Englishmen (educated men, too) doing everything to earn a living, from 'toting a handsaw' (i.e., travelling as carpenters) to 'tending a bar;' everything, that is, except begging, a pro fession foreign to the bracing climate of the North-West.

It was very, very early in the morning when I left my camp on my last day in the mountains. It had taken us nearly three days to reach that point from. Hope on the way out, and I was bent on reaching Hope that night. There was very little risk of mistaking the trail ; but as I bade 
good-bye to old S., he shook his hoary head, and expressed a conviction that I should certainly get no farther than the fourteen-mile house. That was the last glimpse I had of the old man, in his shirt-sleeves, slowly arranging a diamond hitch on one of the pack-animals, and, smoking the eternal meerschaum, dignified leisurely, and (as usual) airily clad, although the snow was on the ground, and the snows of time upon his head. Though no one will ever succeed in making him hurry, I very much doubt if anyone will ever find a better, more considerate, or kindlier old man to 'boss an outfit to those hunting-grounds.' Of course I rode at my pony's best pace along the lonely road, over which a threatening winter sky was hanging, while all the beauty of crimson foliage and sunlight had vanished and made room for Nature's most wintry frown. Those Hope Mountains are just such as should grow a fine crop of supernatural horrors, and the Indian legends show that their looks do not belie them. In another letter I will gather together what creepy stories I know, and introduce you to the beings who people the shadowland of this chaotic region.

On the Similkameen side of the summit we had met large breeds of cattle, untended by men, led only by their instinct, wandering home to the 
prairies from their summer pastures on the uplands, where now frost and snow were gradually asserting themselves. On the Hope side there were no cattle, nothing but forest and gray rock, without browsing for a jackass, and oftentimes the ever-climbing track wound over mere heaps of sharp-edged stones, rendered more grizzly by a crop of burnt pine-stumps. At noon I passed through a lower and warmer belt, where a heavy storm of warm rain made the trout rise splendidly in a broad still bend of milky blue water which came temptingly near my path.

Unfortunately I had the relics of my rod tied to my saddle, my reel and a couple of flies were in my pocket. A strong-minded man would have resisted the temptation and ridden on. To resist temptation means sometimes to miss a chance, and in this instance I felt sure that my charmer who rose so softly under the willows could not weigh less than three pounds. So I dismounted, tied my broken rod together, and soon had two or three good fish out on the bank. But with a broken top I could not reach the big one. There was, however, on the other side of a tributary of the main stream a point from which I could cover my fish. To reach it I must wade through the smaller stream. This, however, meant getting wet to the waist, so, rod 
in hand, I mounted my trusty Rosinante and tried to ride her through. Never had I a worse journey. First, the rod was hard to manage, and the poor beast did not like the deep water, and then I found that my steed was sinking in a quicksand. It was no time to hesitate. Away went the rod, and after a severe struggle through treacherous sand and deep water, I just managed to regain terra firma wet to the neck, and after a very bad five minutes got my horse out, after seeing him flounder, as I thought, hopelessly, with the water well over the saddle. Poor old beast, wet and muddy and hungry, she looked a very rueful spectacle; and I did not feel much more cheerful myself, but that trout was still rising, rising, too, now that the last few drops of the shower were pattering off the boughs with a demonstrative 'flop' which no fisherman could resist. So being wet, I just waded in, and as the fly lit, an angry swirl in the still water marked a good fish's rush, and away went the line down stream as if it never meant to return. Of course my top joint broke again in every place at which it had been mended, while the butt came away from the second joint. Never did a man fight a fish at a greater disadvantage. My reel was practically separated from my rod, and my rod was in bits. But the line was sound 
and the fish not very unreasonable, so that after five or six minutes he came sailing up to my feet a great bar of crimson. I hardly knew what I had got hold of, for though a salmo fontinalis is very brilliant, I had never seen anything like this before, a fish red all over as the leaf of a sugar maple in September. I have learnt since, however, that all the big trout of the Skagit (of which the stream I was fishing is a tributary) are of this brilliant hue. In spite of his colour, he was a true trout, and hung at my saddle-bow, I should think, a good four pounds, the best fish I ever caught in America. The rod lies somewhere amongst the bushes by the burn-side, buried as it were on the field of victory. There was not enough of it whole to make it worth further carriage. The rain came down after this and kindly veiled the miseries and regrets of my horse and myself, even affording consolation in the thought that the prudent man would have been as wet as the rash one. Dripping and hungry we reached the fourteen-mile house, where horse and man were well fed, the man appreciating the wisdom of the American host who gives a glass of whisky (as a prelude to dinner) to every guest who pays for a meal at his table.

It wanted but an hour and a half at most to 
darkness, when my horse and I took the road again; but to an English mind fourteen miles seems such a little way, that in spite of warning I started cheerily enough. Of course it was dark before I got much more than half-way, in spite of the efforts I made to make the most of the pale shadows of twilight. After them came dense darkness and rain which seemed to sweep along the track in sheets. I could not see my horse's head, much less the narrow trail. Later on, even the horse went wrong. I had for an hour past left the direction entirely to her, hoping she would forgive my sins in the past and not precipitate me headlong from any of the little toy bridges we had to pass into the roaring torrents below. But it was a shock to my nerves when I heard her crashing amongst the brush, felt that SHE was wandering from side to side, and then that sHe had stopped, dead! If SHE could not find the way, I certainly could not; so I just sat still until sHe chose to try again, while a fine little brook rose somewhere near the nape of my neck, bubbled merrily down my spine, and rushed out in twin torrents over my boots. After a pause, poor old Rosinante gave a groan and tried again, appearing to me actually to feel the ground with her nose as she went, her endeavours being rewarded nearly an hour later by 
a glimpse of the lights of Hope. We gained the shelter of the town late last night, and I shall manage to catch the steamer this morning.

Yours ever, C. P. W. 


\section{LETTER XIV.}

My dear Patrick,

It seems somewhat irreverent to describe the men who people a country last in order except for the local spirits and devils whom they fear if they do not still worship them. That, however, is what I propose to do, and I apologize for it by confessing that to me the wild beasts are more interesting than the wild men, and certainly more numerous. The Indians in the narrow valley to which my wanderings were confined are not of the same race, I believe, as the Thompson River Indians; but are the representatives of a tribe of redskins from the Pacific Coast, who, having forced their way in to the hunting-fields beyond the Hope ridge, during the summer months, got snowed in, and, retreat having been cut off, managed to hold their own against their neighbours. Such particulars as I have managed to glean concerning them and their superstitions I owe to Mrs. Alison of Pen- 
ticton, whose nursery, if it has not all the advantages of home, possesses such means of whiling away the winter evenings as compensate for any children's pleasures which the young Alisons may lose. For at Princetown, "when the cold north winds blow, and the long howling of the wolves is heard amidst the snow,' when the ribs of the lordly buck which the boys shot in the morning are roasting on the embers, the door opens quietly, and soft-footed old Quilltasket comes in, his brown eyes bright and keen, and his short square figure clothed in deer-skins and fur, his old wrinkled brown face looking quainter than ever in the flickering firelight. $\mathrm{He}$ is the historian of his tribe, an historian who tells his legends, not in dead written words, but in lively speech illustrated by appropriate action. From him and others of his tribe Mrs. Alison has collected all that seems to be known of the Similkameen clan.

Unlike the Indians of Oregon and Washington territory, the Indians of British Columbia generally appear to have always been peaceful and law-abiding. This is due, say the white settlers, to the fact that even-handed justice has always been administered in British Columbia between white men and red; and in corroboration of this, I remember to have heard grumblings amongst the white men, to the effect that a 'darned Injun 
could do jist what he pleased, and no one ever said nothin' to him.' That was the view possibly of a squatter, who only looked upon Indians as natural encumbrances to the land. In spite of the Roman Catholic priests, who live amongst them and have won their respect, the Indians make but indifferent Christians still. Some of them bury their dead in the graveyards under the cross, others bury them where they can from time to time dig them up to join with the living in a wild and ghostly drinking bout. Very emotional, the half-civilized redskins join heartily in all the services of the church, especially in any Service of Song, and they even have amongst them men who undertake the daily duties of the priest, ring the prayer-bell and have prayers, in the absence of that minister. But the Indian leaves his Christianity behind him in church; marries as many wives as he chooses, though he is gradually becoming sufficiently civilized to think one enough at a time, 'trades' them whenever an opportunity offers for others more attractive, or for more useful possessions, such as horses or saddles, gambles to a very great extent, lies as much as he thinks profitable to him, and gets drunk whenever he gets a chance. Unfortunately, in spite of the stringent laws of Canada, I was told over and over again that the Indians 
' can get all the whisky they want, and do get it.' Even in a single village of Indians you will see individuals in every stage of civilization, the old people preferring to adhere to the customs of their childhood, though nothing pleases them better than to see the younger members of their tribe aping the whites in house and habits and manner of living. In one encampment, by a broad stream among the cotton-woods, you will see half the people living in the old-fashioned 'tuper' (a circular frame of poles, hung over with rush-mats of native make), while the men of this generation have fine white tents of canvas, bought from the stores of Hope, or Yale, or Westminster. In front of the tupers you will find the old people lying on deer-mats in the sun, with extremely little on, smoking pipes of their own make, of a dark green stone; old men and women, not only smoking themselves, but indulging their little boys and girls in a whiff whenever they appear deserving of special favour. Under a pine-tree just outside the camp is a group of gamblers, three boys and an older man, in nothing but a pair of deer-skin pants. This group has been sitting by the fire since the night before, gambling for the boys' wages, which before long will be carried away in the pockets of the deer-skin pants to buy whisky. 
A more pleasing sight is the smart white tent on the top of the river-bank, inside which are beds of bear-skins, covered with good blankets, and even clean white sheets, while woman's love of colour has asserted itself in smart quilts, prettily pieced together from remnants of various bright-hued calicoes. A foot from the door a canvas tablecloth is spread, though the only table is mother earth, and upon this stands the pride of the woman's heart, a gaily-coloured little china tea-service. On the fire hard by sputters the morning meal of beans and bacon, the tea simmers in the bright tin pot, and a greedy-eyed little papoose tied up to a stick is propped against the tent watching the progress of breakfast. Byand-by the chickens attack the frying-pan, or the dog knocks the papoose off his perch, and up comes mamma from the river, where she has been making her toilette, her black hair in long braids gleaming with drops from the river, and her whole person looking bright and clean. Young as she is, the gentleman in black broad-cloth, with a silver watch in his pocket, of which he is inordinately proud, is her seventh husband, the other six having parted with her for various considerations, or having exchanged her for more serviceable helpmates.

A lady's estimate of the Indian women of this 
tribe is, that though not pretty, their faces are pleasing, their figures perfect, if it were not that they are a little square-shouldered, and their hands and feet exquisitely small and shapely. Being shy or unobservant, this traveller is bound to admit that he never saw an Indian lady whom he could distinguish from her male relatives. Certainly all he saw wore blankets of brilliant colours in much the same fashion, and sat astride their horses with masculine firmness and freedom. But then, Pat, you know I would rather face a crocodile than meet a ladies' school, or any other female.

Yours truly, C. P. W. 


\section{LETTER XV.}

Dear Pat,

I promised you some Indian fairy-tales. The following is the best that I can do for you. Half the legends which do duty as history among the red-men of the Similkameen have for their hero the Tumisco; a chief of the tribe which dwells near Princetown, and the immediate predecessor and father of the reigning potentate, In-cow-market. It was through In-cow-market that the stories reached my friend Mrs. Alison, who handed them on to me ; and upon In-cowmarket's head be the shame if they are false, and the glory if they have in them some of the wild poetry of that stern country from whence they came. I read them first by the flames of my huge camp-fire upon 'the summit,' and wove them into their present shape as I rode in solitude and darkness under the tall gray pines, on that night of storm described in my last letter. It may be that I have thus rolled many legends 
into one, and condensed the lives and adventures of several chiefs into a type of the race. If so, forgive me, red heroes; the stage on which I have to make you dance is but a small one.

Like all the men of his race, Tumisco was a mighty hunter. Upon him his aged parents might count with certainty for food and game to make their old hearts glad. Never in all the years did Tumisco let his parents lie down hungry. The deer and the sheep died before his arrows; and even the white goat died, that its horns might tip the bow of hard mountainspruce carried by the chief when, stripped to his smooth red skin, he crept nearer and nearer to Callomeha, the great grizzly bear, until he could hear his breathing and watch the flank of the monster heaving evenly in sleep. Then Tumisco's arrow flashed through the air, and Callomeha died to make beds of soft fur for the stranger-guests of Tumisco. It was upon the mountain Chippaco, the cloud-bearer, that Tumisco had one cvening slain a she-bear. It was too late to return to the camp, so the chief slept in the yet warm hide of his victim, his good horse tethered beside him, and the bear's-meat piled high between horse and man to protect it from the fierce wolves of the mountain.

Dark and grim were the mountain shadows, 
and the pale moonlight was weird and sad, while the wolves howling and the winds were the chief's lullaby. But, born to such scenes and used to such music, Tumisco slept. At midnight he woke, roused by the loud snorting of his horse Nehoggets. With one wild bound that gallant beast snapped his reata, and clearing his master's recumbent form, fled with the speed of the night wind. Tumisco listened. Beside him was a sound as of the tearing and rending of flesh, and between him and the moonlight stood, gigantic and terrible, Soni-appoo, the Spirit of Evil, feeding on the fresh bear's-meat. Tumisco's cheek blanched for the first time since childhood, and, shrinking closer into his bloody bear's-hide, he trembled lest the wild beating of his heart should draw the fiend's attention to him. Then Tumisco felt a mist rise round him, and his heart died, and all became a blank. When the morning sun rose life returned, and the chief sought his people, and together the whole clan scoured the mountain to find and slay Soniappoo. There they found him stretched in slumber, his great arms spread among the pinetrees, his huge black face turned with closed eyes towards the sun, his breathing laboured and loud. In silence the warriors surrounded the demon, and bound him with ropes and reatas; 
flight upon flight, thick as hail in winter, flew the arrows, when the great Soni-appoo yawned and awoke. As he stretched his hairy limbs, ropes snapped like dry grass; the arrows fell idly back from his iron hide; and as he rose, those daring ones who clung to his long silky black locks were lifted up half as high as the pines, and, as the demon shook his head, fell feebly back to earth. With a laugh of scorn Soni-appoo turned, not deigning to crush the pigmies at his feet, and hid himself in a thunder-cloud, in which the terror-stricken Indians heard his laugh die away among the crags of Chippaco.

It is well to hunt the deer in the open, or in the sunny glades when the morning is fresh and young; but the shadows of the tall peaks, and the caverns at their feet, hold terrible shapes towards evening. The children of the tribe remember the story of Kee-kee-was, father of Tumisco, and shiver as they dabble in the little trout-stream, where, years ago, he set his fishtraps. In the winter the brook is a raging torrent; but when summer has reduced it to a noisy silver thread, it is full of bright trout. Here, day after day, Kee-kee-was caught enough trout for his whole tribe, until suddenly the run seemed to cease, the traps were empty. Kee- 
kee-was suspected foul play, and lay out all one moonlight night to watch. Towards morning he heard a loud shrieking whistle, like the sound of the north wind. Nearer and nearer it came, and now he heard a tramp of feet which shook the solid earth on which he lay, while a suffocating smell of garlic filled the air. Too terror-stricken to move, he lay until a great hand seized him and lifted him up and up until he opened his eyes on a level with a great face, whose jaws dropped open and emitted a laugh loud as a thunder-clap. But the big man was kindly, and his eyes gentle. Stooping, he took up Kee-keewas' blanket, rolled him up in it, and then, putting the unfortunate fisherman in the bosom of his shirt, filled a basket with trout from the traps, and strode away towards a cave among the peaks, whistling like a winter storm as he went. In the cave was another big man, just in from hunting, two fat does hanging from his belt as grouse hang from the belt of an Indian.

For days Kee-kee-was lived, tied by the leg, in the giants' cave, kindly treated and fed by them, but deafened by the thunder of their conversation, and choked with the odour of their cave. Huge as they were, they cried if a fish-bone pricked them, and towards one another these bearded white-skinned monsters were gentle and 
loving as women. At last Kee-kee-was escaped, and now, when the traps are empty, no man sits up for the poachers.

It would take too long to tell you the story of 'Sour-grub,' the snake-like chief who stole the good horse Nehoggets, and by treachery imprisoned the fire-god in his pipe, and of how Tumisco released the fire-spirit, and by his aid recovered Nehoggets, and in a storm of vivid lightning turned Sour-grub and all his men into those ruinous rocks which lie about in the valley; it would take too long, too, to tell of the gambler brother of Tumisco, who sat up all night with the devil and played for all he owned and lost it all and his life-so we pass on from daylight to darkness, from the chief's life to his death. A dreary wail rises from the valleys; it swells louder and louder, and the voices of Nature mourn in chorus. The pine-trees creak in the wind, the river moans between its hollow banks, the night-owls flitting by hoot to the wolf howling on the mountain-side. What is it Shnena, the night-owl, calls from the gloomy wood to his mate, who sits watching on the tallest pole of Tumisco's tent? 'Poom pa! poom, poom!' he says; and his mate makes answer: 'Poom pa! poom, poom!' (I come for you, I come for you !) 
Round Tumisco's lodge the Indians are singing a low, sad chaunt. Their chief, strong as the bear, wise as the wolverine, is going out, whither his father went, into the darkness and the silence. By-and-by his sister, that wise woman Connuetatio, comes out from the lodge, and bids the warriors bring the Pinto mare, her brother's favourite war-horse; bids them tie her colt and set the mare free, saddled and bridled with the chief's war-saddle, and it shall be, if the mare travel up the valley towards the sunrise, their chief shall live; but if towards the sunset, then shall Tumisco surely die. Kiwas, the chief's friend, leads the mare forth. For a moment she faces the sunrise, and then slowly turns down the valley and follows the darkness.

The night wears on, and one comes riding through the night, riding a steed whose breath is like white smoke in the gloom. It is Scuse, the mighty doctor, from Loo-loo-hoo-loo, the hollow land; Scuse, who chased the spirit of the waters, thinking he chased a deer, until in a valley like Eden, sweet with the scent of syringas, and fresh with springing water and cool, deep mosses, he came upon the great Gemmo-gemmohesus, the friend of man, whose bat-like wings perpetually fanned and beat the air, from whose brow the broad antlers rose above a face like the 
face of man but for the covering of deer's-hide, and the great kindly eyes in which neither anger nor cruelty dwell.

With Gemmo-gemmo-hesus (the Spirit of the Waters) Scuse dwelt, while two moons waxed and waned, until he had learnt all the arts of healing, and the kindly spirit set him free to go back and help his brother man.

Now Scuse comes hurrying through the night to fight and wrestle with the evil spirit which was destroying Tumisco. At the bidding of the medicine-man the warriors pile high the pinelogs, whose bright flames banish the gloom and light up the darkness. Then from outside the circle of the firelight comes a thing like nothing known on earth. It has the beak of an eagle, the claws of a bear; round its body is the hide of a buffalo; round its neck is a necklet of dried toads, while its girdle is the skin of a snake. It is Scuse in his armour-Scuse, who will peck out the eyes of the evil one with the eagle's beak, tear him with the claws of a bear, and make him writhe with the poison of toad and rattlesnake. Singing and dancing in the firelight, Scuse tempts the evil spirit to the fray. At last he prevails. The devil leaves Tumisco; the chief sits upright, and watches whilst the medicine-man and the spirit wrestle together for his life. Little by 
little the doctor's efforts fail, his breath grows faster and more faint, the hand of the devil is at his throat, he shrieks and falls in a swoon, mastered. As he falls, Tumisco's strength fades, he lies back in bed, and his eyes grow dim. Anon the medicine-man rises from his swoon, and confesses that he is vanquished. Tumisco must die at sunset next day; there is no more hope. Connuetatio assents; "there is no more hope ; Tumisco dies at sunset.'

So the young warriors are bidden to mount and ride hard east, and west, and south, and north, to bring in the guests to the funeral feast. The warriors go out, and now the long day dawns, and grows warm, and begins to grow old. It is near sunset. Scuse has said Tumisco dies at sunset. Connuetatio, his sister, has said it. The sun is low down, and still the chief lives. It is not meet to watch his last struggles. Throw a buffalo robe over his head. Yet another and another! What, does he still breathe and struggle? Pile on, then, more rugs ! So! Ah, the sun is down. Lift the robes! The chief Tumisco is dead! As the shades of evening fall, the women cut off their long tresses and blacken their faces, that their faces may reflect the gloom of their hearts. From far and near, guests come in to the funeral feast. Huge bon- 
fires are lighted, and the dead man in all his finery is laid out amongst the guests, who feast and make merry while his portion is given to the flames to devour, along with the gifts which his neighbours bring to the dead. In the darkness, the chief's horses are led round and round his corpse. His sisters make presents from among them to his nearest friends; the rest are driven out into the murky midnight pursued by the assembled warriors, lassoes in hand. What each captures is his to have and to hold. At dawn the guests dig a deep grave, and lay therein gifts and robes, and last of all their chief, his bow and arrows at his feet, his knife in his hand. Then they cover him from sight, and pile high the stones above him, that the wolf and the coyotes may not disturb the sleep of the mighty hunter. Here for three years Tumisco rests in peace-the dead have no place among the living - the snows fall and melt into his grave, and he is forgotten. At the end of three years there is a whispering in the village: women hide their heads, strong chiefs shudder for fear. Orola, the young brave, saw it last night—-saw the tall gaunt thing rise from the grave of the buried chief; heard its sighs and lamentations; saw it go whirling and whirling down the valley, fire and smoke coming from its jaws, its grave-clothes fluttering on the night- 
wind. His heart fluttered like a snared bird and stood still. When it began to beat again, the thing was gone. Now it is at the sister's lodge that there is a tapping, which is not the tapping of the woodpecker - a rustling that is not the wood-rat, looking for his food. At length they can stand these visitations no longer. Scuse, the medicine-man, is sent for. With charms and songs he entices the uneasy spirit to a mat, draws him thither, and binds him upon it with a mighty spell. Then he cross-examines the spirit of the chief, and finds that Tumisco is discontented because he is forgotten; his sisters have ceased to mourn for him, other men ride his horses, his dogs follow other men to the chase ; moreover, no funeral feast has lately been held in his honour, and his grave-clothes are musty and mouldy with decay.

This Scuse looks upon as a well-founded cause of complaint. The spirit is released, and Scuse and the sisters convene a meeting of the tribes to hold a merry-making with the dead, who is disinterred, each Indian lifting a bone, whilst their mouths and nostrils are stuffed with sweet-smelling grass. The bones are laid in a new sheet. The old grave-clothes are burned. Gifts are presented to the chief; like scaloolas (or carrion birds), the warriors dance and flit 
round the grave in the night season, and until morning dawns carouse madly with the corpse. Then at last they lay the poor bones to rest in their deep dark house of silence, where neither howl of gray wolf nor sneaking coyote can disturb the chieftain's sleep. Far away, four days' journey from his village, they believe that Tumisco burns his solitary fire on the lonely campinggrounds of the Hereafter.

So goes the legend of Tumisco and his fellows, when In-cow-market is the story-teller, and the legend gives a very faithful picture of the death, at any rate, of an Indian chief in the Cascades.

It is not in every case that the relatives choke out the last struggling sighs with blankets and buffalo robes, but it is undoubtedly true that, if the Indians want to move their camp, and an invalid whose life is despaired of is inconveniently long in dying, his friends smother him.

The funeral feasts of which the legend tells are costly ceremonies, as you may judge from the following facts in connection with a recent ' wake' at Princetown. The deceased was only a child, but the guests were nearly 100, and the feast lasted two nights. Each night at sunset a beast was slain, and at sunrise not an ounce of flesh was left. One hundred pounds of flour, half a sack of rice, dried apples, peaches, etc., were also 
bought and consumed in the two nights, together with twenty yards of white calico, and several whole 'pieces' of coloured material, half of which was burnt as an offering to the dead, and the other half distributed among the mourners. The waste of goods at these wakes and fêtes is very great, and the fear of ghosts among the Indians is carried to the most ridiculous extent; but it has one excellent result: the debts of the dead are never left unpaid.

Yours truly,

$$
\text { C. P. W. }
$$




\section{LETTER XVI.}

Dear C.,

Stone Buildings,

Temple.

If I write this my humble confession in the meekest of spirits, let that suffice. I confess that the Adirondacks are a fraud; don't write in reply that 'you told me so.' When you tore yourself away from the fading frivolities of Saratoga, we all began to get uneasy and make ready for flight. 'Shamus' was the first to go. I took him down to the station, and with him endeavoured to persuade some one of a score of railway officials to put a couple of portmanteaus on the train. We had omitted some formality in registering the baggage, so these worthies stood at ease with folded arms and smiled at the agonies of the passenger they were paid to assist. My last glimpse of Shamus showed him standing on the foot-board of his car, clutching the end of a gigantic portmanteau with convulsive energy. 
Whether eventually he managed to pull his possessions inside, or was forced to let go, I never heard. The porters were still smiling and standing at ease when I left the station. On the following day I booked myself for Blue Mountain, by the Adirondack railroad and stage-coach, equipped for conquest, whether on the lake or in the woods. What time I had to spare I whiled away by perusing the most fascinating of guidebooks, bound in imitation birch bark, and illustrated with glimpses of a sylvan paradise such as I have never dared to dream of even in my most sanguine moods. In its pages I saw the happy hunter at one moment triumphant over the antlered monarch of the woods, at the next bowed down beneath a burden of fish which (if the angler was a man of average height) must have measured about three feet six inches apiece, and, again, oh, happy fate! issuing from between the tall stems of the hemlocks, he finds the fairest of Transatlantic Circes, swinging in her hammock, and waiting for him as Tennyson's lady waited in old time for the fairy prince. Instinctively my fingers played with my moustache, and I wondered, would she, when I found her, have so many dollars that I might dwell for ever in sight of the Blue Mountain, and never see Stone Buildings any more. Well, I never found her, 
and if finding her meant a life in the Adirondacks, I am glad I didn't. From Saratoga to the Blue Mountain is a twelve hours' journey, most of it along the banks of the Hudson River. The scenery, of course, is delightful, though marred, to my mind, in no small degree by the hosts of blanched and weather-beaten pine-logs which lie stranded on the shores, shoals, and rocks of the river, much as you saw them at Glen Falls, though, of course, in smaller numbers. When a flood comes they will start afresh upon the journey they commenced last spring, until, at Glen Falls, they are caught in the floating boom, and told off according to the trade-mark on their butts, into the partitions assigned to their respective owners. At the railway terminus a stagecoach with six horses met us, followed by a number of buck-board traps for those whose destinations were close at hand. Almost before I had realized what the next stage of the journey was to be, I heard the cry of 'All aboard,' and the coach dashed away at full speed. Luckily I was just in time; but it does not do to linger much in changing carriages if you don't mean to be left behind in America. On the coach I had the luck to meet two young Americans going in, like myself, to shoot deer. They were really good fellows, and, like all their race, hospitable 
and kindly disposed to the strangers. By their invitation I joined their party, and that the more readily as I was informed that in the sport of hounding, the stronger the party the better its chances of success. Their guide, Dick Birch, reputed the best in the locality, joined us on the second day, and reported the country full of sportsmen and very much shot out. His report caused a change in our programme. Instead of going to Blue Mountain, we stopped at Cedar River, picking up two more guides on the way.

I confess I was not sorry to sit down by the porch of the Cedar River inn with mine host, and watch the coach bump out of sight, while we puffed the cool tobacco-smoke and listened to his yarns of a monster brown bear that had recently smashed the traps of the lumberers and roused the woods with his growling. Personally I am of opinion that it would not be worth anyone's while to go to the Adirondacks for bear, although at Walkley's dam our guides said that they came across fresh tracks. The covert is too dense to get at the bears without dogs, and the guides know too well the value of their hounds to let them follow such dangerous quarry as Master Bruin generally proves himself. 'Hounding' is the universal form of sport in the Adirondacks, 
and it was to this that I was entered at dawn next morning. If you observe carefully, you will find that your true American hates exercise, hence the popularity of hounding and duck-shooting. You would not find him enthusiastic about deer-stalking or partridge-shooting on our Montgomeryshire hills in November.

There are three things necessary for hounding : guides who know the deer-runs, and the places at which they generally take to the water; hounds who will stick to their quarry all day long if necessary, and deer. We had both the first requisites, excellent guides and good hounds; but I don't think deer were abundant. As soon as the sun was up, we followed our guides into the timber. Where the big trees still stood the going was good enough, but where the lumberers had felled the big timber, the brush was so thick as to make progress both difficult and painful. Two guides came with the guns to post them, and one (the tracker) took the hounds away in another direction. One of us was posted by a river, another on a run by the river, and a third in a boat on a lake. Our instructions were to stand or sit, and even smoke if we chose; but on no account to change our positions whilst the deer was afoot. I vow that I carried out the guide's instructions to the letter, for a bird mis- 
took me for a $\log$ and perched for some seconds on my shoulder.

But no deer came my way; indeed, I may as well confess at once that, though I tried Cedar River twice and went on to Walkley's dam, I never saw a live deer in the Adirondacks. Two were killed by our party; one by the Doctor, and one by Dick Birch, the guide, the first being an exceptionally fine beast, weighing $220 \mathrm{lb}$. when gralloched.

The bounds are the only interesting element in this form of sport, and it is well worth while to watch them work. The one tracker takes all the hounds, and visits the feeding-grounds of the deer until he finds a fresh track leading to the spot in which the stag has couched for the day. If the dogs own to the track, the man slips a single hound and goes on. More than one dog is never slipped upon the same track, and no dog is slipped on a fawn's track, partly because the game is not worth the candle, but more because a fawn, by circling round and round over the same ground, so stains it as to utterly baffle the hound. When once the deer is roused, the chase lasts on an average about a couple of hours, and to be successful your hound must not only be staunch and utterly self-reliant, but swift to boot; for if the stag is not well bustled he will go clean 
away from the home waters, on which the guns are posted, to some distant lake, upon which probably some other party are at work, and be killed by them. We lost two stags in this way. Only one of our hounds showed any breeding, and he was only a half-bred one, and certainly not the best of the pack. But in spite of their want of breeding their performances are wonderful. After an hour's dodging close to home, the deer would often give the hound a straight run of some fourteen miles before taking to the water, after which the hound would try along the bank for a little while to make sure that the stag had not come out again, and then take up his own tracks, and run heel until he came to the place at which the tracker had started him; here he would take up his master's track and follow it until he found him to once more be ready for work. I remember in Ayrshire a celebrated hound named Woodman, belonging to Mr. Malcolm, of Poltalloch, which stuck to a roe-deer over a ringing run of fourteen miles, bringing the roe back to be shot at the point at which it was roused, and this was rightly thought an unusually fine performance; but it would be only an ordinary day's work for one of these under-bred Yankee deer-hounds. It seems to me that the excellence of these hounds, and the self-reliance and close 
hunting developed in them, is a strong argument in favour of letting hounds alone as much as possible. Having failed to kill my deer, and having made sure that the Circe in a hammock was only a phantom created by the ardent imagination of the young man who wrote the guide-book, I betook myself seriously to fishing, more especially as the camp was getting so ravenous that our host's cow was within an ace of being sacrificed.

There is a professional angler, named Lee Harris, who spends a good part of his year within hail of Fort William Henry Hotel, on Lake George. Of all those who angle for black bass with grasshoppers, for pickerel or lake-trout with 'shiners,' or in any other manner for any other fish, Lee Harris is facile princeps. To him I went for instruction, and as his plumes had been a good deal ruffled lately by the advent of a rival Izaak Walton from Australia, I found him extremely communicative. Unfortunately it was the old story. 'When I first came here,' Lee Harris said, 'there were more fish in the lakes than Dick Birch will tell you there were deer in the forests when he first came along. But it's not worth your while putting them things together now,' pointing to my pile of rods. ' There are a few pickerel (jack you call'em in 
the old country), and some splendid twenty-pound lake-trout still; but these lie very deep in the lakes, and you don't get many of them. Why, when I first came along, if we wanted a few trout, we did not bother with flies, nor yet with shiners, but just rowed our boat out on to the lake and daubed her sides with molasses. "What was that for?" you say. Wal, you see, no sooner was the molasses on than the flies came in thousands, and the trout in hundreds after the flies, and in such a tarnation hurry that they jumped clar over the flies into the boat. The trouble was not to eatch a boatload of trout in them days, but to get ashore before the fish sank you. Ye-es, there were fish in the lakes then, you bet?

And so there may have been, but there are very few now, in spite of the assertions of the guide-books to the contrary. The lakes still gleam like opals among the fiery reds of the maple, the gold of the birch, and the bronze of the oak; still mirror on their surface the tall spiral forms of pine and hemlock; their beauty may still make your eye brighten and your heart throb; but no monsters (or but very few) still dwell in them to bend your rod and wake the merry music of your reel. The Adirondacks (forests and lakes alike) are a wonderful instance 
of what the passion for sport, uncontrolled by proper laws as to close-time and similar matters, can achieve in the way of destruction in a country but recently teeming with game. It is true that there is now an association formed for the protection of the fish and the enforcement of the game-laws, but it must be many years yet before these waters begin to recover themselves.

Except for their beauty and their sweet healthgiving breezes, I wish I had taken your advice and never seen the Adirondacks.

Yours, etc.

J. M. L. 


\section{LETTER XVII.}

Victoria, B.C.

Dear Lina,

Sept., 1887.

If you have had my husband's letters forwarded to you by Mr. E., you must know what he has been doing for the last three weeks. I flatter myself that you would a great deal rather know what $I$ have been about. ' I want you to stay at Victoria,' my husband said on leaving me, 'and see if you think it would be a pleasant place for you to live in.' I have been obeying him to the letter, and I find that Victoria, with no household worries, would be charming; and Victoria, even if you had to keep house, would be decidedly bearable if you were lucky enough to get a good Chinaman. Life here for a woman depends, my dear, a good deal upon the Chinese, and your reputation as a mistress in Chinatown is one of your most valuable possessions. If you are lucky, and treat 
your Celestial well, he seems to me to be a treasure beyond price. As a matter of fact, you have to pay him thirty to forty dollars a month as cook; housemaid, and buttons. He is all three, and will do any odd jobs, such as gardening or wood-cutting, as well. He may pass his evenings in the consumption of opium, in playing shocking games of chance, or in eating nameless horrors, but when he comes to your house in the morning he looks fresh and clean as a new printdress. He is not confidential like some English cooks, not talkative even, and if he were, you could not understand him; but he is generally good-tempered, and infinitely better in the kitchen than nine out of ten of the so-called 'good plain cooks' you get at home. But 'John' has his little faults like the rest of us, and the most painful of them all is a habit he has of leaving you without warning, not waiting even for arrears of pay in some cases. My own impression is, that he is sharp enough to have noticed how necessary he is as a domestic to the white people of B.C., and to have noticed, too, that though the number of his people in Victoria has decreased, a fresh class of white servants has not yet arisen to take the place of the Chinamen. It is a terrible thing to feel that if you lose your temper with him, though his face may 
remain utterly unmoved during the storm, when morning comes you may find your household 'brownie' gone, never to return ; and what is more, if this happens often, you will find very considerable difficulty in replacing him. Of course, Lina, life is very different here to life at home. Here you may meet one of your tradesmen in society, half an hour after he has served you from behind the counter. He makes his money by trade, and is not ashamed to own it, in this point only differing from some we meet at home. There is no promenade here, no Row to drive in, no great shops to flaunt the latest fashions in your face, but the Victorians stand on their dignity for all that. My husband thought a pair of very smart knickerbockers, which were good enough for our own country town, would be good enough for the 'high' in Victoria. I believe more than ore member of the club suggested to him that these garments were not the thing to wear in the fashionable parts of the town. As to amusements, we are better off than you would be in any country town at home. I do not count dinner-parties. Those are masculine joys. Women know too much about the preparations for them. But, in addition to dinners, I have had three invitations to dances, four picnics, a theatre, and any number of tennis- 
parties during my three weeks' sojourn in Victoria. So that I have not been such a very desolate and forlorn person in my husband's absence. All through the summer a stream of English visitors keeps passing through the town, bringing memories of, and messages from, home to the settlers.

I wish I could sketch, that I might be saved a description of Victoria; but I cannot, so you must have it in pen and ink. The houses are most of them of wood, gabled, and painted white, detached, of course, and for the most part surrounded by pretty gardens, some of which are very gay with flowers. At the top of the town is the cathedral, and from that point the houses run down to the blue waters of the Straits of San Juan de Fuca. Behind our house lies a beautiful park-like expanse, unenclosed, but reserved as a public recreation-ground. From the edge of it you can look across the waters to the snow peaks of the Olympian range; and if you turn away from them and the water you see that the forest hedges in the town. To give you an idea of the way in which extremes meet here, and how near the forest is to the centre of Government, let me tell you what occurred last week to one of the officers of the flag-ship stationed here. $\mathrm{He}$ was on shore somewhere 
near Esquimalt, the great harbour of Vancouver Island, not four miles from the LieutenantGovernor's official residence, and less from the General Post Office, when his spaniel was knocked head over heels by a panther or mountain lion. Captain S. had no gun, neither had he any intention of letting his dog be mauled by the great yellow cat before him, so, like a gallant sailor, he 'went for' that panther with his walking-stick. The panther, not caring to come to close quarters with her Majesty's navy, 'sheered off' (I think that sounds right for a naval engagement, doesn't it, Lina?), and left the dog and his master to return to their ship in peace. The odd part of the story is, that not only did Captain S. get a gun, come back, and find and kill his assailant, but that the same Captain S. saw another panther the same week rolling in the dust of the road near the harbour.

So you see that though we have most of the luxuries of civilization, we have not quite banished the aborigines of the country from our midst.

With a view to settling here, I have been looking at some of the houses for sale on the island. Here, as elsewhere, you have to pay for position. James Bay is the place for official residences, I suppose ; Nob's Hill is the Kensing- 
ton of Vancouver Island, and there, I am told, the present Premier, Mr. Dunsmuir, is about to build himself a palace. The house I looked at to-day was a specimen of the best to be found in the island. It was built on a stone foundation, the rest of the building being of wood. It seemed solidly and strongly put together, stood close to a main road in about an acre of ground, and was very prettily gabled and finished externally. There were stables, built on a raised platform, in which, I confess, I could hardly fancy that an English hunter could make himself comfortable. There were sheds and barns, and a washhouse, whilst in the house itself there was certainly ample accommodation for a moderatesized family (e.g., father and mother and four children, with servants), and a spare room. The floors were parquetted, the walls furnished with a handsome carved dado; in the reception-rooms there were handsome carved mantel-shelves with framed mirrors above them, and every room was finished in the very best taste and style. The price asked for this house was about $£ 1,500$. I don't pretend that all the houses in Victoria are built in similar style. This had been built to order; but you may form some idea of the cost of purchasing a house out here, and the value you would get for your money, from what I have told 
you. But,mydear, you are not married yet, so what do you want with houses? Let me take you out for a picnic instead, and show you the prettiest side of British Columbian life. It is to be a boating picnic up one of the 'arms' (water-ways) which run up from the Straits into the interior of the island. Some of our male friends are coming to row us up to camp and shoot whilst we sketch and prepare a meal of some sort. Almost as soon as we leave the wharf, the men get out their 'spoons' and let them spin behind the boats as we row slowly up the arm, whose still waters gleam unbroken save for the rise of trout or salmon, or the trail of some duck which scuttles away over the surface as we approach. Here and there bits of red rock crop up on either bank, and on either bank the forest of pine and cedar rises gently from the water's edge.

An enormous number of salmon is caught in these waters every year; but on the day of which I am thinking we caught nothing (save 'crabs') until lunch-time. The men had left us on landing, and we could hear their guns from time to time in the distance. Tired of doing nothing, and incited to effort by the constant rises of two or three salmon in the little bay in which we were, my friend and I took to the boat again and fished hard for a quarter of an hour. 
If a fish won't bite in that time, what can you expect, my dear? Of course we began talking. The fisherwoman let her spoon trail overboard, and to prevent the line following it, whipped one end of the line round her own ankle. I don't know where our thoughts had wandered to; but I know it was very far from fish and fishing, when my companion was suddenly jerked into the bottom of the boat, and at the same moment a great salmon sprang out of the water some yards behind us. For a moment I could not understand what was the matter, until I saw the salmon jump again, and my fair friend's foot being jerked about in a manner which at once suggested that the question between her and the salmon was simply, 'Must I come in, or will you come out?' Luckily two of the hooks on the spoon gave way, and I don't think my friend was sorry to regain her freedom, though in doing so she lost her fish and broke her tackle. By-andby the men came back, not too well laden with game, but very full of excuses. The covert, they say, is too thick and birds scarce. They had a few pheasants and grouse, and some quail. My husband was particularly indignant with the quail, handsome little fellows, with a big dark crest upon their heads. It seems that the moment you move them they are off in a cloud to the 
densest covert they can find. He managed to mark one covey into a fairly open spot amongst the timber, and followed them. As he tells the story, he got a brace from somewhere when he next put them up, and then one after another he caught glimpses of birds just disappearing amongst the tree-tops in the distance. He could hear them on the wing all the time; but though he liept his eye carefully on the fern, he never saw one rise from it. At last he saw one whirl out of a little pine-tree, and on looking closer saw another perched there watching him. One after another he put the birds out of the trees, in whose branches they had lodged, and came home vowing that the most uncivilized things in America were the grouse, who sat in tree-tops until you stoned them to death, and the quail, who behaved more like tomtits than game-birds. Whatever their shortcomings may have been, the calls of the scattered bevy made very sweet music as we rowed leisurely home towards nightfall to where the harbour lights were already gleaming on the quiet wave. There is no use in denying that the atmosphere of Victoria is peaceful and restful in the extreme. It is not only the dreamy languor of the night to which I am looking back which has impressed me; not only the stillness of San Juan's waters, or the shadows of the 
gigantic Douglas pines; there is something else besides all this which makes Victoria essentially a place for rest. Some day it may be as bustling as Chicago or Liverpool, when its coal-mines shall have been developed, and their dependent manufactories established; but it will be an outrage to Nature if it is so, for if ever there was a haven of rest designed by the Creator upon earth for weary brains and tired bodies to refresh themselves in before they go hence and are no more seen, it is beautiful Victoria. If only my husband would give up the world and all its pomps and vanities, I would be only too glad to live out the rest of my life in this land of sunshine and sea-breezes, doing all I could to tempt my friends at home to come and share my happy lot, and amongst those friends, you first, dear Lina.

Yours, etc.,

J EnNie P. W. 


\section{LETTER XVIII.}

London,

Dec., 1887.

My Dear Pat,

It is Longfellow, I think, who asks:

'How canst thou walk in these streets, who hast trod the green turf of the prairies?

How canst thou breathe in this air, who hast breathed the sweet air of the mountains?'

Looking with the dyspeptic eye of the body upon the dense yellow fog and filthy slush of the streets of London, and looking fondly back with the eye of memory to the crystal clear skies which hang over Canada, this is a natural question to ask, a difficult one to answer.

Perhaps it is best to avoid the question. Here we do not walk, we crawl; we don't breathe, we choke.

Ah, well, let me close my physical eyes and open the eyes of memory.

It is November, and a great train comes 
tearing along the Canadian Pacific Railway line. It has travelled some thousands of miles through forest and lake-land, has been delayed by a trifling accident, by which two freight-trains have knocked one another into match-wood, and now is tearing along at unwonted speed through the night to make up lost time.

Most of the passengers in the Pullman have sought their sleeping-berths, but two, a lady and her husband, are standing about, parcels in hand, apparently waiting for something to happen. She looks sadly sleepy, and half inclined to cry. Byand-by the conductor comes through on his tour of inspection. 'Say, are you really going to get off the cars at N. ?' he asks. 'What! you are! Waal, I guess you'll strike it pretty rough. Yes, sir, you'll strike it pretty rocky. Train stops ninety seconds, and maybe you had better take a lucifer with you to light yourself a fire on the prairie;' with which encouraging remarks he passes on. Soon a bell begins to toll sadly, and the train slows down a little to pass through a town of very green-looking wooden houses. There is a sigh from the air-brake, and for a breathing-space the cars pause at a platform. The two travellers jump out, and their home for the last few days rushes away and is lost in the darkness of night. There is a small crowd on 
the platform, and, thank Heaven! an omnibus of sorts. The pair (myself and wife) enter the 'bus and are driven away, feeling thankful that the guard's lucifer has not been needed. It is too dark to notice much, but that there is a very nipping and an eager air about to-night, before we draw up with a jerk at our inn. The driver dismounts, hands out the lady, and calls for his wife to come and look after her, in the broadest Irish.

Whilst the lady is inspecting our quarters for the night, Mr. McNamara persuades me to 'thry a dhrink,' and applies himself to the discovery of my motives in visiting ' No-matter-where.'

'Is it the gould they've been finding lately you'll be wanting to see, sorr?'

'No, McNamara', I reply; 'I can't afford to look at gold-mines; I've come to try to get a moose. Are there any hereabouts?'

'Any moose, is it? I do assure you, sorr, that I just wonder we weren't jostled by them as we came to the hotel,' replies the truthful Gael.

Such reports are all very well at night, but in the morning facts have to be faced and dealt with. A law has been passed prohibiting the slaughter of moose altogether in one half the neighbourhood, and the local Indian hunters, 
having given up all hope of the advent of white hunters for this season, have gone off to their winter shooting-grounds some hundreds of miles back in the forests.

For almost the first time that I remember in Canada there is no sun shining. The town is only six years old, and its site very imperfectly cleared. The hotel itself rises from a rough boulder-strewn building-lot, not yet made level; the wooden trottoirs rise a couple of feet above the thoroughfares, in which only so much ground is cleared as is actually needed for traffic; boulders and tree-stumps still cumber the ground, and through all sweeps a broad gray river, sheeted in mist, and fringed near the town with a long line of red canoes beached for the year.

Low hills, covered with hard wood, abut on the river; and wooded hills and timber-limits stretch far away on all sides.

The day looks dim and gray, the river lifeless and desolate, the hills forbidding; the sun has a thick haze round it, and there is promise of snow in the air. In the few shop-windows nothing is to be seen except furs and sealskin moccasins. A cart in the yard is being taken off its wheels and being mounted on 'runners.'

The last leaves of autumn have fallen; the sugar-maple has lost its gold and crimson, and 
stands out now, stark and grim, in its nakedness against the sky.

A wind tears through the new wood houses, and the whole six-year-old town feels without the sun as cheerless as a camp without a fire, or life without hope. ' No-matter-where' is waiting for the winter. To-day, and under such circumstances, one requires consolation. It is a difficult article to obtain, but there is a store here at which you can get most things-a Canadian Whiteley's, the store of the Hudson Bay Company. There we are met by a courtly grayhaired old gentleman, ready to assist us in everything, one of a class which has wielded for good immense power amongst the North American Indians, and which even up to to-day holds the affection of the red man by treating him with invariable loyalty and good faith. To this gentleman every Indian in his neighbourhood is known, and most of them obey him like children. His best hunters, he tells us, are away; but there is one man who may do, a quondam lumberer, now busy with carpenter's work in the town. A boy goes for Jocko, while we inspect the store, in which are laid out all the real necessaries and most of the comforts of life-moccasins worked with flowers for the house, rough sealskin moccasins for the snow, scarlet blankets for cloaks or 
bed-covering, sides of bacon, guns, knives, and a few prettily-worked Indian trinkets. In a loft above the store are piles of mink and marten skins, beaver and fox skins, hides of moose and cariboo, though as yet the winter's hunt has hardly begun.

Nothing could be higher than the character Mr. — gives his Indian friends. It seems that each hunter has his own particular range, and it is a point of honour among them not to poach each other's preserves. Hunger, of course, has no law, so that a redskin who is hungry allows himself to kill a beaver upon a neighbour's ' shoot;' but having done so and eaten the beaver, he is bound to keep the skin, and at the yearly delivery of pelts to the Hudson Bay Company, he hands over the skin, neatly wrapped in birchbark, to the factor, and requests that he will put it to So-and-so's credit. Every year Mr.

has to make note of several such transactions. Credit is given to the Indians by the company sometimes for more than a year, and such things as bad debts do not occur in the company's books.

In a few minutes Jocko arrives, a short, squarebuilt half-breed of forty or thereabouts, dressed in European clothes, and an abominable 'bowler' hat. His feet only wear the natural Indian dress ; moccasins are about the last of the com- 
forts of backwoods life which the half-breed yields to civilization. Jocko smiles all over his face at us, and shakes hands.

'Do you think, Jocko, you could find this gentleman a moose?'

'I think so, maybe,' replies Jocko ; 'but who is to do my work?'

'Oh, I'll manage that for you,' replies our friend the factor; "I'll get Charlie Bonamie to do it for you.'

'All right,' replies Jocko.

'When can you start?'

'To-morrow morning, I guess; but I must take Frank with me; he's a good boy, and can cook fine !'

And so it is arranged that we start on the morrow in the early morning, with Jocko as hunter, Frank as cook, and cart and outfit supplied by our friends of the Hudson Bay Company.

Now as to stores! For once Mrs. W. does not do the shopping. No doubt she can order the dinner and lay in stores for a week, at home in Kensington; but this is another matter, and so I confer with the factor, and make my own list, many years' experience having taught me exactly what I want for such work.

'Whatever you do, don't forget the bakingpowder, Worcester sauce, or onions.' 
'All right, sir ; but won't you take a few little luxuries for the lady?' replies the clerk.

'No; I want her to really rough it.'

Madame laughs, and the man thinks we are mad.

'Put in salt pork instead of bacon for us,' says Jocko; 'bacon is no use in camp.'

'Why not, Jocko?' I ask.

'It isn't fat enough; you want fat for cold weather and hard work.'

Of course I make no demur. The pork is the cheapest, and I am quite ready to consult my men's tastes.

Next morning, at ten, an extremely smart cart on wheels stands before the store, loaded with rugs and buffalo robes, and drawn by two strong horses.

The lady has come up to the scratch gallantly, arrayed in scarlet tam-o'-shanter, short skirts, stout boots, and overshoes to keep out the snow. Instead of the gigantic trunks which generally accompany her, one little hand-bag holds all her clothes and toilette necessaries for a week. All mine are knotted up in a handkerchief. A case like a large hat-box contains a pail, and in that pail, ingeniously fitted, are pots and kettles, frying-pans, knives, billies, and all the kitchen utensils necessary for comfort round a camp-fire. 
There is one box of provisions, and another (a very modest little fellow) full of bitter beer, and one (just one) bottle of whisky in case of-well, let us say cholera.

In spite of my desire to let my wife see a genuine specimen of camping out, it seems to me that our expedition is going to be as comfortable as an English picnic. A cheer for the lady, a waving of hats, and off we go, a French Canadian driving, and our two Indians tucked in behind. All round 'No-matter-where' are lumber limits, i.e., tracts of forest taken up and owned or leased by different individuals who, every fall, send gangs of axe-men into their limits to hew down the harvest of oak and pine. For sixteen years Jocko had been a lumberman, vowing every year that the hardships of the life were too great, and that he could earn more money in the towns for lighter work; but every fall when the gang gathered together and prepared to move off to the great $\log$ shanties for the winter, the old fascination drew him after them, and once more in bright tuque of blue or red, axe on shoulder, and pipe between his teeth, he marched off with the merry singing crew of stalwart fellows for the forest. Even now that he had given it up, Jocko hankered after the old life. How many of us professional men in London, if we could be 
altogether free to choose, would not for a season straighten our backs and swing a woodman's axe in preference to driving a scraping quill along the foolscap !

The men when lumbering live in gangs in great wooden shanties in the depths of the forests and in the midst of their work. Each shanty has its cook and its store-chest, from which each man purchases his week's provisions, his weekly bill being deducted from his weekly wage. Round the interior of the shanty (which is built of rough $\operatorname{logs}$ ) are bunks arranged tier above tier, and in the centre burns a huge fire. The men begin work early, and go back early to the shanty. They are able to work fairly near each other, and in the bright and bracing atmosphere blithe. songs mingle with the ring of the axe. At night the shanty is their club. Together they dine and smoke, play cards, spin yarns, and sing. On Sundays there is no work to do, so some loaf, others hunt or fish, or add to their earnings by setting traps for otter, mink, or beaver, and visiting those set last week. This sort of thing lasts until the spring, and then the worst half of the lumberer's work begins. Logs have to be hauled, rafts made and floated down stream to the mills at Ottawa and elsewhere, and in the miserable thaw the lumberer is wet to his waist half a 
dozen times a day. Still, hard exercise keeps the men ' fit' and well, and sixteen years of the work had not bent Jocko's shoulders or dimmed his brown dog-like eyes. A dollar a day is about the wage paid now to lumbermen in the limits in Ontario and Quebec. But I am wandering away from the track along which our horses are taking us at about five miles an hour to such a shanty as I have described, situated in a limit which has been deserted for some three or four years.

The pace at which we travel is a bad one, but the country is a very Arabia Petrea outside the town, and it really requires steering to get safely through the boulders. Besides, the roads are made worse by snow which fell nine days ago, not deep enough for sleighing, but quite deep enough to make driving on wheels peculiarly slow work.

Here and there by the river's bank a small farm has been hewn out of the forest. These farms are fine instances of what Mr. Pell, in an able article in this year's Journal of the Chamber of Agriculture, calls the making of the land. Perhaps the happy settler only gave in the first instance a pound an acre for his land; but by the time he has felled the trees upon it, cleared the stumps and rocks out of it, built the fences upon 
it, protected it from floods, drained it, built upon it houses and barns, the amount of money and muscle, the years of his life and his children's, will represent an accumulated capital sunk in the soil worth more than the seven to sixteen shillings per acre at which land in the provinces of Ontario and Quebec is now let. But the pioneer's reward 'is in the race he runs, not in the prize,' and as we drive past we envy the sturdy fellow his strong health, open-air work, manly labour, and that pleasure which comes of creating, and seeing the home of your own creation grow beneath your hands. They are quaint homes, some of those inside the heavy snake fences of rough logs, built of heavy pine stems, well fitted and filled in with mud or mortar, roofed with wooden slates, and painted sometimes in the most brilliant of colours, as if the inhabitants had rebelled against the eternal white of winter, and the green gloom of the summer woods. One little shanty was called the Maison Dorée, and was gabled all over, had dormer-windows put in wherever there - was room for one, and was painted a bright yellow. Before we had been on our way two hours, the Indians and our driver wanted to lunch. No one else did; but I suppose they were sick of the bitter wind, which cut our ears almost off, in spite of the flaps of our deer-stalkers, 
so we all bundled out, lit fires, and cooked bacon by the road-side. After wasting an hour and a half in this way, we again started, our lame horse (he had a stiff leg, result of a fracture in youth) almost running away with us. At about four we left the road, which for the last half-mile had been very bad, and turned into the forest. A drive of 100 yards sufficed for everyone, except the driver and my wife, over the forest road, and as the driver candidly remarked, it did not seem likely that any of their bones would be left in the proper places by nightfall. First on one wheel, then on another, the unfortunate trap careered through snow and ruts, over logs and rocks, sometimes leaping a little brook, at others stopping for a fallen tree to be cut out of the way.

Except for the noise we made and the chattering of some squirrels alarmed at our arrival, intense silence reigned in the woods. The track we were following was one which had been sufficiently cleared for the lumberers in times past to haul the logs along to the river; but it had never been meant for a trap with springs. At last one side of the trap tilted up, there was a sharp metallic snap, and a spring had gone. To my surprise, though the driver grumbled a good deal, he mended the spring with a small log and some straps and proceeded. I quite expected to 
hear him talk of turning back and giving up the road as impracticable. This was explained afterwards. The trap belonged not to the driver, as I supposed, but to our friend the Hudson Bay agent.

The woods were so dense and still, and gametracks so frequent, though most of them old, that I ran on ahead of the cart until the sound of its misfortunes reached me no more, and then strode on, silently watching and listening, in the hope that my eyes might be gladdened by the sight of some of those mysterious forest beasts whose tracks were all round me. At last there was a regular soft footfall on the snow, and, at a turn of the road, I stood face to face with a French Canadian trapper coming out from an inspection of his traps. It was his coat we had passed earlier in the day, tossed casually in the snow by the roadside. It had been there, my Indian said, two or three days, and he seemed in nowise surprised, except when I asked him if it was safe there. 'Safe! of course! why should it not be?' I wondered a little whether my friend Jocko would find it wise to leave a good coat for a couple of days by an English wayside, but said nothing.

In another hour darkness was upon us, and the men wanted to camp. 
'Is this the point from which you meant to start hunting, Jocko?' I asked.

'No; but I guess we can't go any further to-night.'

' How far is the log-hut?'

'Three miles, I guess.'

'Very well, then, go on until we get there,' I replied.

The men grumbled, but one man must always be master, and it is good to teach your men at first that if they waste time by the way, they must make it up after hours. And now the road led over a regular boom, up to which we had to bring the horses with a rush. We had built a gradually rising platform in front of it, and somehow or other the trap got over; but meanwhile our leader Jocko had disappeared in the dim thickets. It was hard to follow him, but we did it somehow-the wife very silent and a little frightened, the driver desperately savage, and horses ' played out.'

At last a point of light gleamed ahead of us, and we could hear the ring of an axe, and in another minute we pulled up between two rough log-huts, one the stable, the other the shanty. There was not much to choose between them; but the shanty, built of rough logs, had a hearth and shelves for sleeping-bunks, and was soon 
full of the red glow of a good wood fire and the savoury smell of cooking.

The shanty had not been used for three years, so that we were not afraid of finding our sleeping quarters too lively; but for all that we turned out the crisp dry brush which the lumberers had used for bedding, and sent it leaping and roaring in great, glad tongues of flame out through the big square hole in the roof to the frosty sky we could see above. Things went well and merrily that night, and even 'the lady' seemed fairly comfortable, and even useful, until, when all else was still save the Indians' snoring by the hearth, a long, wailing howl sounded very near the door of the hut. Then-but I will be generous. A wolf's howl is an eerie sound to those who have never heard it before, and until you know the beast, it does seem reasonable to wish to have the door barred between him and your bedside.

What a change comes over the scene between that last look into the forest at night before turning in and the first glimpse on waking !

Then, as you stood in the doorway, your hut glowed a point of vivid crimson in the night. Every frosted fern or birch bough within a dozen yards of its glow was hung with glittering rubies, while further in the forest the cold moonlight glittered on frosty emeralds, or sparkled back 
from the pure white snow. Then the sky was of deep, deep blue steel, set with points of cold fire. Now the sky has paled, and hangs red and pale blue over a forest of silver filigree, pine and birch and stream all bound in fetters of silver.

Early rising does not appear to be essential in moose-hunting, for it is 7.30 before Jocko has finished packing up his little blue handkerchief full of necessaries-matches, a knife, some bread, a piece of the fattest pork he can find, etc., all neatly stowed away in a bundle not too big to go inside a large stove-pipe hat. On our feet are long sealskin moccasins, reputed waterproof, and reaching to the knee. Over these are the redoubtable red canvas overalls, warranted to wear a year, and excellent for the woods. Our hands are covered first with woollen gloves, and then with fingerless gloves of deerskin, for it appears that in the work before us ordinary gloves are soon worn out. I should advise any who imitate me in this sport to have their gloves soled. The silence of the forest seems to have settled on Jocko early. As soon as he has completed his preparations, he begins to speak in whispers. When he leaves the hut he becomes dumb. For a few hundred yards we swing along down the path, then we turn into a kind of timber-yard of 
fallen giants, and come to a gully with a frozen stream below. Here we crawl along a pole, and I thank my stars that Jocko requires all his attention to keep his own equilibrium, and can't see what a funk I am in. However, we are over, and don't stop to blow. Jocko, I find, never does stop. As we rise the hill the morning breaks upon us, a miracle of beauty. It seems as though a million fairy spears, gem-tipped and silver-hafted, were levelled at us, and along their levelled points comes the sun in a blaze of splendour; or it is a sea of molten silver set in the dark-green pines, with here and there a gaunt trunk, blackened by fire or blasted by frost, rișing stark and stern from it like the mast of a wreck.

Whatever it is, Jocko is wading through it waist-deep, and I follow him, the scales of frost rustling down crisp and dry from the big marshtea-bushes and the birch-boughs. For a good hour we fought our way through the frosted brush, and climbed over the snow-covered logs, or, Blondin-like, walked along them. In moccasins it is easy enough, but I should be sorry to try it in boots. Here and there we got glimpses of the marshes, low-lying tracts without trees, covered entirely with the Indian marsh-tea, looking a soft dove-colour in the distance. Close 
to it is an oval-leafed shrub, the upper surface a glossy dark green, and the under surface presenting a yellow, furred appearance. It makes a very good drink, and is supposed to have valuable medicinal qualities.

At last Jocko stooped and pointed to a track, such a track as only a moose could make, of such a size as could only be tolerated in Canada, about six tracks being sufficient for an acre.

'Three days old,' muttered Jocko, and though the track led straight away into likely-looking country, where tracking was easy and going good, he turned off sharp to the right, and once more led me a weary dance over logs and pitfalls until I was too tired to lift a leg. Half a dozen times during the day we came to places where the moose had lain on the tops of the hard-wood hills, or upon droppings as large as plums, composed entirely of sawdust. What a digestion a moose must have, whose most delicate food appears to be withies! Here and there we saw deer-tracks, but no tracks of bear ; and, indeed, but for moose, there seemed very little game in this day's beat, and the latest moose track we had seen was (so Jocko said) three days old. So we sat down on a log, which we partially thawed during lunch, and ate our bacon in silence. Suddenly Jocko's eyes glisten, 
his jaws remain rigidly apart, the last mouthful unswallowed, and somewhere far back in the bushes I hear a movement. Very faint at first, but suddenly Jocko grips my arm and points. I can see nothing. Yes, now-I can't. For one moment I caught a glimpse of a brown form on the jump. I think I had a glimpse of a long white fur, and though I did snap at my first white-tail buck, I don't consider it worth while to go and look if there is blood on his trail. I am conscious of having fired somewhere in his direction, and that is about all.

There are no birds, no life anywhere. Whatever is in the forest (and you can't help feeling that it is full of live beasts) is endowed with ghostlike silence of tread, and the power of remaining invisible. But now, as evening falls, Jocko seems to have given up the moose, and is keenly studying the exceptionally large heart like slot of a white-tail buck. We are in a hollow, and round us are low hills covered with hard-wood and fallen timber. The edges are clearly defined against the frosty sky, and what is that on the very crest of one of them? Surely it is a great buck, though his back is straight and rigid as the pine butts lying round him. As he has seen us it is hopeless to try to get nearer; Jocko shakes his head as I raise my rifle, but I take no notice. 
$\mathrm{Up}$ to his shoulder I come, and then raise the sight till I am clear of him altogether. It is flukey shooting, but what am I to do with a rifle only sighted for 250 yards, and a buck looking at me from double the distance? As the sharp report rings out, the rigid form at graze on the hilltop bounds high in air, just touches with his knees a huge pine-log in front of him, and apparently plunges head-first into space. 'Our meat ; that's good,' says Jocko ; 'come on after the other,' and starts at a run in an opposite direction to that in which my buck is lying. At first I follow, but when he pauses, find time to whisper : 'What are we after, Jocko? was there another big buck?' 'No, this not a buck, this she-deer,' replies Jocko. 'Oh, hang you !' I pant out indignantly; 'come along, and make sure of mybuck.' Jocko hankers after more meat, but obeys. Arrived at the crest of the hill there is a place where a buck stood and stamped; there is a huge log to clear, which he must have jumped, seven honest feet, and on the other side there is the mark of his fall, head first in the snow, and that is all. No, stay ; about a quarter of a mile off on a barren hill, my wounded beast is limping along about half as fast as I could run at my best. For a moment I feel that I must imbrue my hands in the blood of the noble savage, but I 
refrain, the more readily as at that moment he is some considerable distance out of reach, going like a winner of the Grand National over all sorts of impediments which speedily stop that noble animal. By dint of using my hands more than my feet, I follow him for about half an hour. Then I see the stag standing, looking back at me about 150 yards off. I am sobbing like a brokenwinded cab-horse after breasting Highgate Hill. I miss him like a man, both barrels. Jocko says nothing; he does more ; he runs again and I try to follow him. The dusk is turning into dark. I cannot possibly go another hundred yards. But the stag is getting done too. That first shot hit him in the shoulder, and just as I am about to drop from sheer exhaustion he lurches heavily, stumbles, recovers himself, and then comes down with a crash-dead, but game to the last gasp. Jocko and I lay and panted beside him in the snow, and then, having skinned him and admired his branching antlers-really fine antlers for a white tail, and the strange long white fud from which he takes his name-I ask how far it is back to camp. 'Maybe seven miles,' says Jocko, and maybe he was not exaggerating. I know the moon was up, and I had got tired even of looking forward to the luxuries of hot mutton and whisky toddy before he announced that it was only three 
more miles to camp. 'We'll be in in an hour, I guess, if we keep this pace up, but there is some bad travelling ahead,' said my guide, puffing away at his pipe. 'Bad travelling ahead !' I wondered what he considered the fallen timber, half hidden in snow and rendered doubly trappy by the halflight through which we had been travelling ever since dusk.

All at once a report woke the night echoes, and then another. "What the devil is that, Jocko!' I ask. Jocko looks surprised for a moment, and then answers, "Guess your girl got frightened; shooting to let you know where the camp is ; better answer.' I have six cartridges left with me and only twenty more in camp, so somewhat grudgingly I comply. At once my reply is answered, and as I don't respond more shooting ensues. ' Confound them, Jocko, they'll use up all my ammunition.' ' Never mind, just one more shot,' says the Indian. And so it went on, until about half my ammunition had been expended, and we could hear an eldritch scream made by the Indian Frank, from the bluff above us. A quarter of an hour afterwards we stumbled over the doorstep into the glow of the firelight, and when we saw the magnificent repast spread for us, and listened to the raptures poured out over the stag's head we hung on the beams, 
we forgave the camp-followers, whose noisy solicitude for our welfare must have frightened all the moose in the province.

The day's work for those in camp had not been a dull one, nor, as far as we could judge by the beds of fresh pine-brush and the dish of trout, an unprofitable one. That night, our buffalo-rug covered as tired and happy a couple as any out of Paradise ; nor was it until the long howling of an old gray wolf, not far from our door, awoke the lady, that she felt either fear or discomfort in this somewhat savage nest. However, like most wild beasts, wolves fear men even when asleep more than men fear them, and being a sensible woman, Mrs. P. W. accepted my assurances on this subject, and for the rest of her stay in our log shanty, rather looked forward to the wolf's serenade as part of the programme of the beautiful forest nights.

You should see, Pat, if you cannot induce your wife to try a Canadian lumberer's hut for a change. No-matter-where is better worth visiting than Brighton, not more dangerous, and less expensive.

Yours truly,

C. P. W. 


\section{LETTER XIX.}

Dear Pat,

London.

You ask me for the story of those great ungainly antlers which you saw cumbering my little London house. They were moose-heads, my boy; antlers which I obtained at No-matterwhere last autumn, when my wife was camping with me.

You must come with me in fancy to the rough log-hut, amongst the pines, and imagine that it is early morning on the last day but one of my stay in the forest. We have been in nearly a week, and until now, for nine days in fact, the thin carpet of snow in the forest has remained unchanged. It was written all over with records of the wanderings of the tall red deer, but during all those days the snow has been crisp and hard, the air dry, and the skies bright.

Every footfall, however light the moccasined foot which made it, crackled noisily among crisply 
frozen moss and leaves, or broke with a sharp crunch through some thin crust of ice. Yesterday there was no snow at all in many places, so that tracking for any considerable distance was out of the question. Up till this morning no luck has befallen us in our moose-hunting, though we have worked steadily from dawn to dusk for four days.

The morning of this, the fifth day, is breaking, and the corner of my buffalo robe has got up.

There is no doubt about that, for the morning air, keen as a wolf's tooth, has got in and set me shivering.

A soft footfall stealing about the shanty mixes somehow with my waking dreams; by-and-by a thin flame flickers up from the hearth, and a bevy of red sparks rushes up through the great chimney into the gray sky.

A change has come since yesterday. The sky has lost its crystalline quality, and when a minute later Jocko opens the door and goes out with the chopper, a glimpse through the open doorway confirms my waking impression that something has happened in the night. There is no longer that crispness of light and sound which was the bane and the beauty of yesterday.

The friendly red flame flickers up again, and, encouraged by it, I slip out and stand for a minute, bare-footed and shivering, by the hearth. 
Jocko enters, with a huge log upon his shoulder, and there is a smile in his big brown eyes.

'We've got the snow now,' he says, ' and plenty of him.' The change is explained. Outside everything is soft and white. There is a soft, heavy look in the gray of the morning sky; the ground is soft with six inches of piled snowflakes; heavy and soft they hang upon the balsams; carpet the ground, and cling in patches even to the grim trunks, still standing gaunt and black amongst the brûlé.

The old records are blotted out, and a clean page of forest history lies open before us. If ever a day promised well for the moose-hunter, it is to-day, and our spirits rise at the thought.

Fearlessly we tackle the tin bucket, in spite of its thin coating of ice, and splash about vigorously on the wood-pile in the corner, which serves for our dressing-room.

The coffee-pot simmers merrily, the bacon hisses an unnecessary invitation to breakfast, and even the damp moccasins, hanging from the clothes-line by the fire, are put on almost without a shudder. Madame alone remains proof against the voice of hope, curled up and content now that she has all the buffalo robe to herself.

At seven Jocko and myself steal out from the 
fire-lit shadows into the stillness of the new day.

On the trail the snow is nearly a foot deep, and I am glad to follow in my guide's footsteps through the drifts. Here and there we step on an unseen log or boulder, and sit down with little ceremony and less comfort, the snow driving up coat and shirt-sleeves, and freezing where it touches the warm flesh.

So far there is not even the track of a squirrel on the path, and it is not until we reach the 'crik' that we come across the first wolf's trail.

The ice may bear his gaunt carcass, but we have to cut down a couple of small trees with which to make some sort of a bridge before we attempt to cross over.

For six miles we held along the main lumberers' trail, passing some other deserted shanties en route, round which a jungle of raspberry-canes has grown up. Inside upon the walls are great hazel hoops for stretching the skins of beavers, a trap or two, and an axe-head. These belong to Jocko, and have been here since last winter. 'Not a bad bear,' is the first remark Jocko has made since leaving our camp-fire, and, looking in the direction in which he is pointing, I see the bark torn from a great tree, some nine feet or more from the ground. Here, probably, Bruin 
(a black one) has been digging his claws in, and stretching himself after a square meal of raspberries. Half a dozen times before eight o'clock we came upon ' white-tail' tracks, leading always into the thickest of the balsam-woods. They look very fresh and tempting; but we are not after white-tail to-day. Just as the hands of my watch point to 8 a.m., my Indian and I stop simultaneously, and my heart begins to go several beats per minute faster than it has done hitherto, for there, right across the track, are the great hoof-prints of a bull moose, fresh, of course, for the snow has hardly ceased falling. Without a word, Jocko turns into the hard-wood, and for an hour neither of us speaks, but both plod on, following yard for yard where the bull has gone. Every moment I expected to see the great spreading palms of his antlers or his huge misshapen bulk moving slowly before us, nibbling the tender tops of birch or willow.

From the top of every hard-wood hill we look to see him lying down, a brown mass, in the snow, resting after his night's tramp. But no. One hard-wood hill after another is climbed and left behind ; one belt of balsam after another penetrated and passed through, and still the great tracks lead on, with no sign of resting or weariness. At last Jocko stops and draws down the 
end of a tall sapling, still bleeding from the teeth of the bull. Turning to me, he speaks (to my horror) above' his breath: "He has been here about two hours ago, and he's travelling to find the rest; if we find him, we shall find them all.' So then, Jocko is expecting to come across a gang of moose; I only hope he may be right, though one, if he is big enough, would do for me. At any rate, from the tone in which my careful Jocko speaks, it is evident that he does not think our senses need be kept on the strain any longer just at present, so, though we keep going, we ease down a little and look about us. In front of us is a tree whose scratched bark and broken twigs show (Jocko says) where our beast has rubbed his horns. Further on the deep furrow-like track of an otter going down to the marsh catches the old trapper's eye, and I see him making careful mental notes of the very numerous signs of marten on the outskirts of the balsam patches. At one moment we pass through a long thin wood of birches, whose every tip bears marks, old or fresh, of the teeth of the moose; at another we pause to look at a hole in the ground where the white-tail has been pawing up a bulb. Our quarry is taking us now in a line parallel to the main line of marshes round which the hard-wood hills gather, and which may be a 
part, for all I know, of that great chain which stretches from the St. Lawrence to the Great Bear Lake in the far North-West. Along this chain of lakes, 'some of them as large as European kingdoms,' the moose still wanders in large gangs, and will wander, in spite of the lumberer's axe and the hunter's rifle, for many a year to come. The only wonder is that man manages ever to come across the great beast in his forest fastnesses.

It is about three o'clock when the track leads into a very heavy grove of balsam, floored with dwarf hemlock and the tea-bush. Here the snow is tremendously deep, almost knee-deep in places, and the heavy wreaths on the dark balsams half smother us as they fall.

Here, indeed, is an ideal home for the oldfashioned King Christmas of the fairy tales of our boyhood. Our moose seems to have been as much enamoured of the scene as we are, for his track wanders in and out, backwards and forwards, in the most aimless and wearying fashion. In a little snowfield among the balsams he has indulged in a pas seul, springing from side to side in huge bounds, and generally having a good romp round. But even here we can get no glimpse of brown hide or branching horns, and still the trail leads on, until we debouch on the 
most perfectly ideal lake of the woods, frostbound, snow-clad, set in dark solemn pines as in a frame, through which the red glow of evening forces its way into the twilight of the woods. Here the moose has found his mates, and here, thoroughly tired, we lunch at about 3.30 , having been going without snow-shoes since 7 a.m. Never before did I realize the value of fat. Tired, and in the severe cold, my stomach loathed even the comparatively lean breakfast-bacon in my pocket, and craved for the solid fat in Jocko's brown fist.

'Indian right, you see; lean meat no good for hunting, all very well in town; but salt bad. Indians never had colds before they used to eat salt,' he muttered, pecking away with a stick at the ice beneath his feet to get a drink. Still as the woods seem, and empty of bird life, we had not stood five minutes eating our hurried lunch before there was a twitter in the branches above us, and looking up, I saw we were observed by half a dozen pairs of bright hungry eyes belonging to blue-tits and golden-crested wrens. No doubt they did well on our crumbs when we had gone. Poor little mites! they seemed so tiny to be out alone in the snow in those great gloomy woods.

Having found the moose, Jocko proposed to return, but to this I could not consent. To-day 
was ours still, I argued; but who knew what surface ice, sudden thaw, or fresh snowfall tomorrow might bring? No, Jocko ; on, on, my friend; even a moose cannot travel for ever without resting. We soon found this was so, for in the deep woods round the lake, two or three knolls bore traces of the mid-day siestas, here of one, there of a gang, of the great bulls. Unfortunately we found, too, that some of the beasts had got our wind and gone. In these balsam labyrinths, the moose seemed all round us, and it was impossible to avoid alarming some of them. With the obstinacy of my race, I insisted on sticking to the bull whose track I had first struck at 8 a.m., and as luck would have it, at about 5 p.m. I was rewarded. Creeping wearily to the top of a knoll, I saw him standing below me in the twilight, still as a stone, so still that it seemed almost incredible that the great creature which must have been moving within a couple of hundred yards of me was really flesh and blood, and not some monstrous forest shadow. There is only one beast in the world which shares with the moose that weird and old-world look which is so peculiar to him, that rough, striking, though uncouth outline of figure which suggests that he and the Rocky Mountain goat are two of Nature's first-born, made in the days when the gray world 
was young, before Nature had time to do more than put force into her models, ere yet she had leisure to smooth down their outlines.

There was a flash, a sharp report, a huge form dead on the snow, and the latest invention of man, a 450 express, had killed one of Nature's first-born, and after all, when we came alongside, the head was so poor that but for the dim light and the distance, even after my nine hours' chase, I would gladly have spared my bull to roam on many a day through lake-land and pine-forest.

I think Jocko said it was nine miles home trom the point at which I killed my first moose; but to me it seemed as if hardly two hours elapsed before it was again dawn and we were again on the war-path. There was a grand old bull amongst the gang I had tracked yesterday, and I meant to have one good head as reward for the long days I had spent amongst the snows.

I won't recount our second day's wanderings amongst dark balsams and by frozen lakesfavourite fighting-grounds of the moose in the early autumn-but hurry on to late afternoon. We are amongst the balsams. Jocko's face is quite drawn with excitement. I am trembling with fatigue. Suddenly he stops, carefully dusts the lock and hammers of my rifle, which he has been carrying for some time past, and then, though he 
absolutely has not spoken all day, lays his finger on his lips, and, crouching like a cat, creeps on. For quite a quarter of an hour we steal silent as shadows through the snow, and then he stops, his eyes ablaze with excitement, but his figure rigid. Slowly he stretches out and passes me the rifle, and signs to me to look across the gully. Two hundred yards away in the big trees a great brown form is moving slowly. I get glimpses of his body, but cannot see his head. 'Shoot, shoot that one,' whispers Jocko. 'Shoot, or they'll be gone.' I only see one, and only a small patch of him from time to time between the pine-stems. However, I fire. 'No, no; there, there he is now,' whispers Jocko, and again I fire at what looks like my beast, going at a trot through the timber. The smoke hangs, and as Jocko clutches my arm and points to a brown patch standing still between two pines, I fire again, as he whispers hoarsely, 'Steady, don't hurry; he won't give you another chance.' As I fire, Jocko snatches the rifle from my hand and goes off at best pace across the valley. Another miss, I suppose (though why, as I am a fair shot at any rate, I cannot guess), and with my blood up, fatigue forgotten, follow at my Indian's flying heels.

For half an hour, it seems to me, we run and stumble on. What does the fool expect, I wonder. 
The moose, if I have missed him, won't stop again between this and the Arctic Circle after such a fusilade. But I recanted my thoughts as they passed through my brain, for there, like great statues of stones in the middle of the snowy path, with heads turned to see what we were who followed them, stood three bull moose, the pine-boughs and snow-wreaths over them, and the dim depths of the forest beyond. The one next me was the big bull of the gang, and my heart longed for the grand antlers which looked so gigantic against the white background. 'Take the front one, he isn't wounded, and you will get the three,' whispered the murderous Jocko. Taking no notice of him, I fired at my bull. The hammer fell with a click, but no report followed. Miss fire! Again-and this time my bull drops dead in his tracks. As yet I have not moved, and the other two, bewildered, stand and gaze back over their great quarters at us. 'Fire again, fire again !' Jocko almost shrieks in my ear. 'See you damned first, Jocko,' I reply in very good English, and dropping my rifle, I throw up my hands with a yell, and have the pleasure of seeing the two great beasts crash through the forest with bounds which, though clumsy, cover a great deal of ground, and soon take them out of sight. 
Jocko was very wrath, and, standing looking at the grand head thrown back on the snow, the huge horns looking black against their background, I didn't care how angry he was.

If only I could have brought my moose of yesterday back to life and sent him after his fellows, I should have been quite happy, although I was dead beat, and had ten miles through the snow between me and my dinner. After gralloching my beast, Jocko, still grumbling at my suicidal folly in not firing, rose to return. Imagine my disgust, when I heard him console himself thus : 'Ah, well, there's the other two bulls safe enough anyways.' And I am sorry to say he was quite right. My first two shots had been as clean as if made at a target, and though moving through thick timber at 200 yards, the two bulls lay there dropped dead in their tracks, each with a bullet behind his shoulder.

I make no boast of the shooting, though to shoot a moose moving through timber at that distance is not so easy as the size of the beast would lead you to believe. They were good young heads and well worth keeping, but I would have given a good deal to have missed them, and so avoided an unwarrantable slaughter and unwitting breach of the game-laws of the country. Those who have shot moose in these dense forest 
and know how little of the beast you sometimes see, and how the smoke hangs in certain conditions of atmosphere, will believe my story and forgive my mistake. Of course, to Mr. Jocko, meat was meat, and each carcase was worth about 25 dollars to him. This accounts for his action in the matter, and it is easy to see how such excellent hunters and shameless butchers as he may and will, if not carefully watched, destroy vast quantities of Canadian big-game.

For moose to shelter in from the wild winds and bitter cold, those deep balsam woods, with their mounds and hollows, their barricades of fallen lop, and drowning depths of soft white snow, may be well enough; but for the weary hunter ten miles from home, with the moon just beginning to show palely in the sky, they are a very Slough of Despond.

All day Jocko and I had been too careful to talk; now we were too tired to do so. In the woods it is small wonder if men become taciturn. A vacation spent moose-hunting in a Canadian forest might be a pleasant relief and wholesome discipline for some of the more loquacious amongst our legislators.

To-night, luckily, we had no need to worry ourselves about the nervousness of those in camp, for my wife had already gone back to No-matter- 
where, leaving me for ' just one more day.' And it was well it was so, for when we stood by the 'halfmile crik,' the moon was well up and the night well advanced. To cross the 'crik,' which was forty or fifty feet wide, we had felled some small trees and made with them a platform over the ice, which swayed unpleasantly as the trees bent under Jocko's weight. As I crossed after him the principal tree smashed in the middle, and before I knew where I was, I was up to my armpits in the icy flood. A cat could not have got out quicker than I did, but for a moment I felt as if the chill had stopped my heart beating. Tired as I was, Jocko and I raced over the logs and snow between the creek and the shanty until, utterly exhausted, I threw myself down by the blazing logs, and let the boy divest me of what remained of my hard-frozen overalls.

Next morning I walked back to the town, starting at early dawn and getting in about 3 p.m., as quaint a sight as any hunter ever presented. The overalls, which were originally of stout red canvas, consisted now of a waistbelt, short gaiters with fringed edges-the connection between the aforesaid points being maintained by an exceedingly choice pair of flannel pyjamas of the brightest cerulean blue. It speaks volumes for 
the primitive simplicity of the place that no one seemed to notice the odd costume much.

The tracks by the wayside upon the freshlyfallen snow were very interesting, as showing how, in spite of the houses, and the hunters who dwelt in them, game still abounded at their very threshold. I tracked one buck along the road past three log cabins, two of which were tenanted. He must, in the early morning, have passed within a few feet of one of the houses. Within a mile of the town, two more deer had crossed the main-road two or three times about sunrise. Of course these were all white-tail, whose quiet skulking habits enable them to live in comparative safety in timber, however close to a town. 'Hounding' alone is likely to destroy or drive away these pretty beasts, and 'hounding'-i.e., hunting with dogs, which drive the deer to a gunner stationed on the runway or deer's path-is in many provinces wisely prohibited by law.

Let me finish this letter with a story of one of my predecessors which should be a warning to critics of works of art. The Major had slain his moose. He had slain many a great beast before, and had a fair right to consider himself a judge in matters connected with natural history. Fresh from the forest he walked into the Hudson Bay Company's store, and was warmly welcomed 
by his friend the agent. As he stood, he noticed in the passage leading to the outside yard a young moose set up.

'Hullo! where did you get that moose from?' he asked.

"Oh, one of the Indians brought him in. What do you think of him?' replied the agent.

'Well, he is pretty well set up, well filled out, and carries his head in a natural way enough; but, you know, he is much too high in the quarters for a moose. That's where you fellows always make a mistake.'

'Do you think so, Major ?' grinned the agent, and turning to the moose, ' $\mathrm{Hi}$, Jack !' he shouted ; 'come and apologize for yourself !'

The great beast, a yearling bull, lifted his head, woke from his day-dream, and shambled up to his master! Beware, Pat, how you criticise my trophies after that!

Yours truly,

C. P. W. 


\section{LETTER XX.}

Dear Reader,

Since I have decided to publish these letters, it has been suggested to me that, as a thank-offering for the good sport which I enjoyed last year, and as an atonement for that act of poaching which I hope I recorded with becoming sorrow, I should attempt to draw up a short résumé of the game-laws of the different provinces of Canada as they stand at present.

It may be that this has already been done by someone better qualified to do it than myself. If it has, I can only say that the number of men who apply to me for information on these subjects proves that my predecessor's work is not as much read as it deserves to be. Moreover, the game-laws of Canada change as rapidly as the face of the country, and already what was allowed last autumn has been prohibited by this year's law. 
Sometimes it is the entire disappearance of a game beast which causes an alteration in the law; sometimes it is the advent of a comparatively dense population in a country where, a few years ago, the only means of support for the casual wanderer was the slaughter of game in season or out of season. Whatever the cause, the fact remains that even the Fish and Game Club of Montreal is not thoroughly posted up to date in the game-laws of the different provinces of Canada. I don't want to libel my countrymen, but I think it is true, as a general rule, that they are possessed with the idea that there are no game-laws out of England.

This, of course, is a very grievous error. The Canadians and Americans, for instance, are far too near akin to us to let their best field-sports perish without a struggle to preserve them.

For awhile they have been so busy making a new world and building up a new people, that they have somewhat overlooked such minor matters as the protection of wild beasts in a country which they found almost too full of them. But the extinction of one species of great game, and the ominous decrease in the numbers of several other species, has thoroughly awakened our cousins to the necessity for protection.

America as a whole (Canada and the United 
States) is following rapidly in the footsteps of older states. Because it is in the nature of man generally to be improvident, to cull the pleasure of the present greedily, without due regard for the probable needs of the future, it has been found necessary in all civilized countries to impose certain restrictions, in the nature of gamelaws, upon the rights of the individual.

In Great Britain these laws concern themselves with two matters - the protection of the public against the recklessness of the individual in destroying game at improper seasons, or by inexpedient methods; and the protection of the private rights of individuals with respect to game, by the infliction of a penalty for game trespass in excess of the penalty for simple trespass to land. In Canada (and, I believe, in the States) the law is content, as a rule, to disregard private rights in these matters, and to busy itself only with the protection of the interests of the public by the imposition of a close time.

I say ' as a rule' advisedly, for in Manitoba, at any rate, the rights of the landowner or of the occupier in game, on his own land, are protected by the infliction of a penalty for trespass in pursuit of it ; and the fishing rights of riparian owners in certain Canadian rivers are also admitted by the law. 
After wading through the statutes of the different provinces, it will only seem natural that I should add my voice to the voices of those who are already pleading for co-operative legislation, not only between the different states in the Union and the different provinces of the Dominion, but also between the Union as a whole and the Dominion as a whole, with regard to close times for American fur, fin, and feather, and also for a simplified code of laws in respect to game.

It is surely absurd that there should be such difference between the close times of different adjoining provinces as to make it lawful, for instance, to kill a snipe a month earlier on one side of a river than on the other.

Besides the absurdity of such laws, they defeat each other by throwing difficulties in the way of the successful prosecution of those who break them. Further on are set out in tables the close times for big game in the different provinces and territories of Canada respectively.

Where no close time is accorded to any particular animal, it is either because it is accounted vermin, or is not supposed to exist in the province under consideration, so that these tables may afford a glimpse of the natural history of each province as well as a notice of the measure of 
protection given to its wild denizens. All penalties of a pecuniary nature inflicted by the game-laws are paid in whole or in part to the prosecutor, whether an individual or a society. This is very necessary, as the protection of game throughout Canada is mainly due to the energy of certain clubs of sportsmen, whose expenses are somewhat lightened by the receipt of such fines.

Canada labours under many disadvantages in her attempt to protect her great game; but the greatest of all her difficulties arises from the fact that the Indian still exists, and is not amenable to all the laws as the white man is. Because, in times past, he depended on hunting for his existence, the redskin is still allowed to kill in season and out of season, so long as, 'by reasonable presumption, the game so killed may be deemed for the immediate and personal use of the Indians who kill it, and not for sale or barter.' I believe, however, that this exemption of the Indian from the operation of the law is being daily curtailed.

There is one beast of whom no mention is made in the game-laws of any of the provinces. I mean, of course, the buffalo. It is commonly reported that this beast, which ten years ago still existed in vast herds, is now as extinct as the great auk. This, in spite of the evidence of 
men who ought to know, is a mistake. In the autumn of last year I had certain and reliable information of a herd of about eighty not many days' journey from Medicine Hut, and of another smaller bunch in another part of the country. In addition to this, there were three heads exhibited in a naturalist's window in London this spring; the buffaloes themselves having been slain last autumn by a couple of young Englishmen, just down from Oxford.

Some sportsman, without reproach himself, will probably feel inclined to inveigh bitterly against the men who secured these trophies. Undoubtedly the buffalo should be preserved, and he who slays more than one specimen deserves all the reproaches which can be heaped upon him; but, brother sportsman, don't you feel inclined to pray with me, 'Lead me not into temptation'? Do you think that if you or I met a lonely bull, even if he was the last of his race, or nearly so, we should spare him? I believe you or I would only take one if we came across a herd of a thousand; but I know that, lawfully or unlawfully, I should feel terribly tempted to kill 'just one.'

From the reports current in British Columbia, I have not the smallest doubt but that there are still plenty of buffaloes in the Peace River country, 
and a notice appeared very recently in the Evening Standard, to the effect that a herd a hundred strong had been found in a remote part of Texas, and that an expedition had been sent out to drive this herd into a certain enclosure for preservation.

One of the results of the extermination of the buffalo appears to be that a fierce war is now being waged upon his kinsman, the musk ox ; for in Montreal and Quebec nowadays, the rug which adorns the sleigh, and was always wont to be a buffalo robe, is now musk ox. A more serious result, so some of the North-West men allege, is that the water-holes at which the herds drank are now drying up; while the water-fowl, which used to come in thousands, now scarcely come in tens. The tramping hoofs of the buffaloes used to cake the bottoms of these pools, which now crack, so that water leaks away. 


\begin{tabular}{|c|c|}
\hline 圆通 & 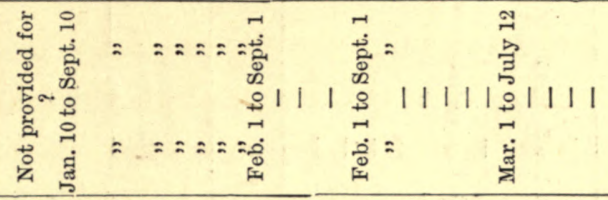 \\
\hline 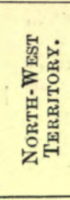 & 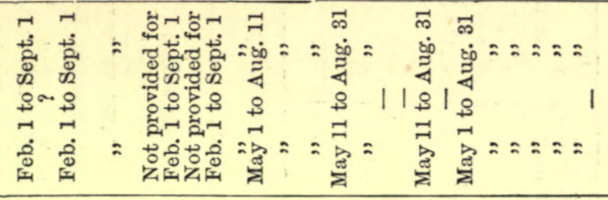 \\
\hline 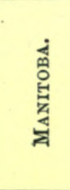 & 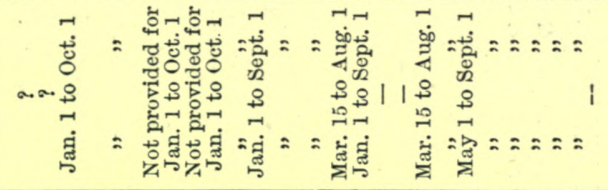 \\
\hline 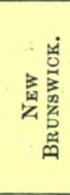 & 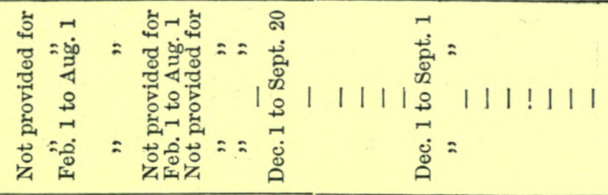 \\
\hline 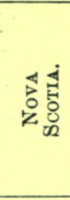 & 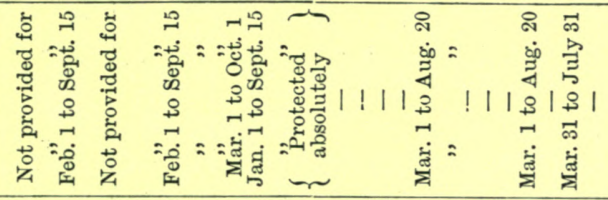 \\
\hline 宫 & 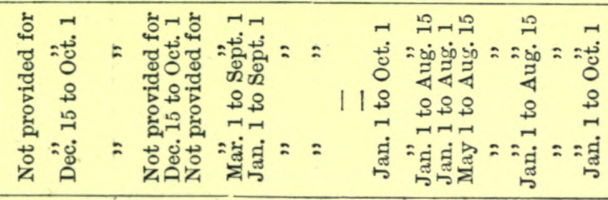 \\
\hline 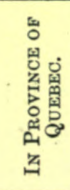 & 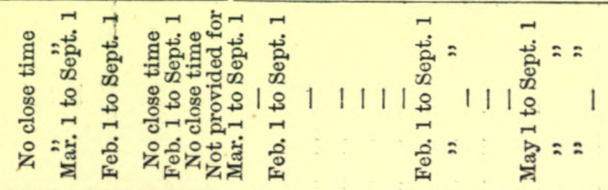 \\
\hline 递 & 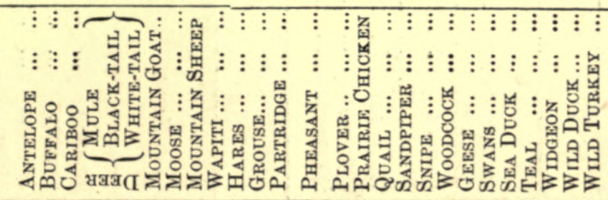 \\
\hline
\end{tabular}



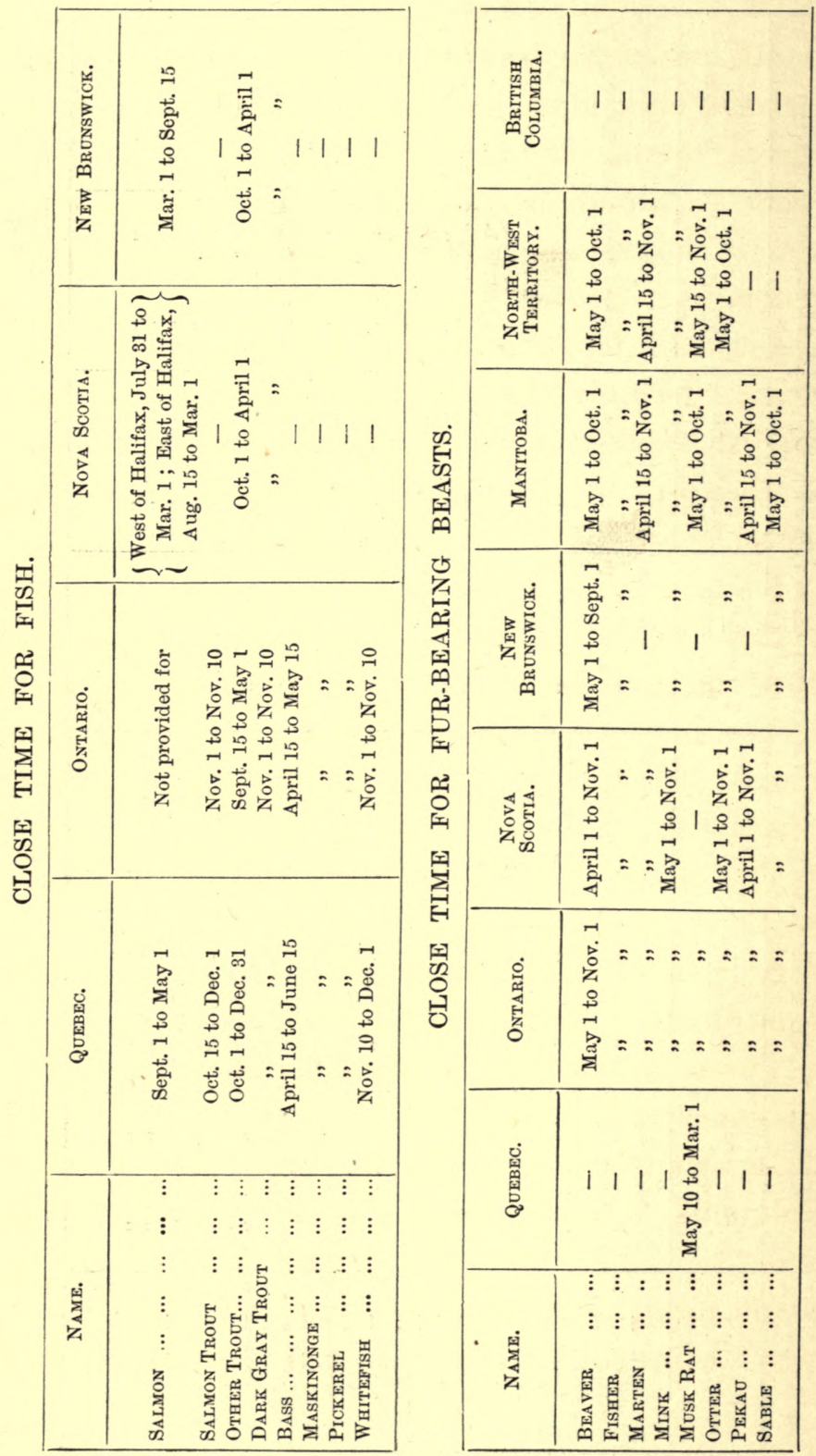
All other fur-bearing animals, such as bears (grizzly, cinnamon, and black), panthers, wolves, lynxes, foxes, skunks, etc., are not protected, being expected, as Mr. Whitcher says of the bear in his report on the Banff National Park, generally to protect themselves.

Besides the knowledge of close times, conveyed, I hope, by the foregoing tables, the English sportsman should remember that in some of the provinces he must procure a license to 'sport' at all.

Non-residents in Quebec are expected to take out a license to hunt, the cost of which is 20 dollars. The omission to take out such a license may be punished by the infliction of a fine of 40 dollars. This applies also to New Brunswick.

The annual license for non-residents in Nova Scotia is 30 dollars.

A license must be taken out in Ontario, though I am unable to ascertain the cost of it.

These licenses are obtainable from the Commissioner of Crown Lands.

In Manitoba, the North-West, and British Columbia, licenses are still unnecessary; but here, too, there are wise regulations which it would be suicidal on the part of English sportsmen to neglect. For example, in Manitoba, 
wildfowl may only be killed with an honest shoulder-gun; batteries, swivel-guns, and puntguns, are abominations to Manitoba.

In a speech lately reported, it was asserted that pheasants were now very numerous in Vancouver. This is hardly the case. There are pheasants there, and they are doing fairly well, but want a great deal of protection, and it would be well if the clauses of the game-law which make it an offence to kill hens at any season, or purchase pheasants of either sex, were more strictly enforced.

An immense amount of harm to the interests of true sportsmen in America is being done by the traffic in trophies. I alluded to this in a former book on shooting on the American continent ('Trottings of a Tenderfoot'). That was written four years ago, and I spoke there rather of the States than of Canada. The trade in heads has, I think, increased, and the damage done by the Stony Indians round Calgary, employed, I was told, by a white man who blends the professions ' of Methodist minister and skallawag' (i.e., skin-hunter) in one person, is enormous. Indians, unfortunately, as I before stated, are not, as a rule, bound by the game-laws which bind the white man; and far from regarding a natural close-time, a favourite dish with them is 
the body of an unborn fawn taken from its dead mother.

There are times, in early spring, when any fool can kill the half-starved mountain-sheep and goats, or even bears; a time when any loafer is active enough to kill the hind, heavy with young ; but men who do these things should not be encouraged by the money of those who would hang trophies on their walls that their friends may think them Nimrods.

In Nova Scotia, New Brunswick, Ontario, and Quebec, a limit has been put to the number of head which each hunter may kill per annum.

In Nova Scotia no one man may kill more than two moose and four cariboo in each season.

In this province the use of a dog in hunting moose or cariboo is punishable by a fine of 25 dollars.

In New Brunswick a more liberal allowance of game is made for each man, to wit, three moose, five cariboo, and five deer.

Here, too, deer-hunting with dogs is prohibited.

In Quebec two moose, two cariboo, three deer, was the largest bag allowed per man per annum until the close of 1886 ; but I understand that no more female moose are to be killed until further notice; and the report was current in 
the province in the autumn of 1887 that the killing of any moose (bull or cow) until 1890 was illegal. Up to the date of writing this I have been unable to get any definite information on this point.

Two of the most fatal methods of destroying game in the lumber-region used to be by 'hounding' and by snaring moose. Both are illegal now, and in Ontario, as the close-time endures until October 1st, it would seem that 'calling' could no longer be successfully practised by those who wish to abide by the law.

Moose are snared by means of a springe attached to a strong young tree by the side of one of their most frequented paths. Caught by the leg in this springe, they are hoisted almost off their legs by the tree, which their struggles have released from its bent position, and spend days perhaps of helpless misery until the poacher despatches them with a bullet from a safe distance.

This noble beast falls an easy prey, too, when 'yarded ;' that is to say, when, having chosen his winter quarters, he has collected all his clan together in a kind of fold trampled out of the deep snow. Seventeen were killed on one day in the winter of 1886 , by one Indian, who came across them under these conditions. He did not 
even attempt to sell the greater portion of the meat.

Some of the terms in the foregoing tables are a little misleading, and require explanation.

The Canadian partridge is the ruffed grouse. There is no true partridge in Canada.

Pekan and fisher are two names for the same beast, Mustela Pennantii.

Sable and marten are synonymous terms.

Some idea of the strong inclination of the Canadians of to-day to protect their beasts of chase may be derived from a perusal of the proposal to establish a National Park at Banff, somewhat similar to the American Yellowstone National Park.

The site was explored and reported on last year by Mr. Whitcher for the Dominion Government, and his recommendation is that an area of some twenty-five square miles should be set apart as a breeding-ground and asylum for all manner of harmless or useful beasts, birds, and fishes, such animals only to be destroyed as he considers noxious to the others to be protected.

Fish are to be bred, and birds and fish imported. Rice to make a shelter for wildfowl is to replace poorer covert, and belts of timber as a hidingplace for the hinds heavy with young are to be at once an ornament and a useful adjunct to the park. 
It will take time to repair the ravages of the miner's giant powder and the Stony Indian's Winchester repeater; but if energy and wisely: spent money will attain these ends, no doubt our cousins over the water will attain them.

I cannot conclude this chapter without a word of hearty thanks to Mr. Just, the librarian of the London Agency of the Dominion of Canada, and the gentlemen of the Fish and Game Club, and Star newspaper, of Montreal, for the efforts they have made to help me in collecting the materials for this little sketch.

P.S.-Since preparing these pages for press, I have had my attention called to a short note, by Colonel Ridout, in one of the May numbers of the Field, in which it is stated that certain important amendments of the game-laws have just been made by the Ontario Legislature. I feel certain that that gallant officer will have no objection to my availing myself of his information so as to bring my notes 'up' to date.

It seems deer may only be killed from October 15th to November 20th. No one person may kill more than five deer in the same season. The shooting of moose is absolutely prohibited until 1895, and until that date no person, unless he has resided at least three 
months in Ontario, and is in possession of a license, may kill any deer or other game.

May I, in parting from my reader, express a hope that he will, if he goes to Canada for sport, pay the same regard to Canadian game-laws which he would expect a Canadian to pay to our laws? and if he does so, may he be as successful as his obedient servant,

The Author of these Letters. 


\section{POSTSCRIPT.}

Dear Reader,

London, 1888.

I cannot help adding a postscript to these letters, begotten of observation of those things which are occurring round me in England as I write. A London spring is dreary enough in all conscience, for those whose business compels them to pass night and morning along the streets between the West and the East, or through the mephitic vapours of the underground railway between those poles of London life. But when the traveller has but just returned from the bright pure climate of Canada; when at every other turn he meets stalwart navvies with their hands in their pockets, proclaiming in dreary sing-song that their families are starving, and that they have got no work to do, then, indeed, the March fogs look sadder than ever, and the bitter east wind overcomes even the most buoyant spirits with its churchyard chill. 
It is at such times as these that the superb love of fatherland, or inexplicable inertness of the human race, strikes the spectator with full force. That professional men stay in England is comprehensible enough. Such a climate as ours at this season of the year naturally produces ample employment for the doctor and the lawyer. No constitution, however strong, could resist the east wind of a British spring for many years after the cooling of boyhood's blood; no temper, however sweet, remain unimpaired by its attacks. 'Liver' and the litigious temperament thrive naturally in our sweet London spring-tide. Besides all this, professional men are not in great demand abroad. In Canada, for example, the professions are just as crowded as they are at home. But with the labourer it is different. If he has nothing to do here, there is enough for him to do across the Atlantic if he is willing and able to do it. If he is neither willing nor able, or unwilling or unable, then, of course, he will be as useless and unpaid and unhappy there as here. For my part, I cannot help thinking that some kinds of paupers are best cured, like biliousness, by a course of starvation. It is true that on April 27 last the Canadian Government discontinued the sys: tem of assisted passages for English immigrants, and that there is an outcry at present in Canada 
against the constant influx of British and other paupers. But the only paupers objected to by Canada are those who insist on remaining paupers, who insist on living on charity, and will not or cannot work. It must be remembered that it costs less to get to Canada than to any other English colony, and that, in spite of this fact, Canada has continued to offer assisted passages to English immigrants after every other colony except New Zealand has ceased to do so ; and New Zealand only assists those who can show that they will arrive in their new home with money sufficient for their support at the outset. If a man cannot by some means acquire the tiny sum of four pounds, sufficient to pay his own passage to Canada, he is hardly likely, argue the Canadians, to have sufficient 'grit' to ensure success in a new country.

But listen to what Sir Matthew Begbie, our Chief Justice in British Columbia, a man of long and real experience in the country, said in 1885 , when answering questions before the Commission on the Chinese Question. 'I never heard,' he said, ' of any person, white, black, or yellow, who had labour to sell that was worth buying who could not in this province find a ready employer. But in order to get remunerative employment here or anywhere else in the world, a man must 
be able to do remunerative work. The misery is that many men who profess to be willing to turn their hands to anything, know nothing to which they can usefully turn their hands. The normal rate of wages is five shillings for Chinamen, and in Victoria eight shillings for white men. Below that rate, no white man, even if penniless and starving, is willing to engage upon any work or service whatever. Skilled artisans, carpenters, masons, blacksmiths, ask from twelve to twenty shillings a day. Board is advertised at many hotels at sixteen shillings a week, so I suppose eight shillings a day is remunerative to the workman,' etc.

This was written, of course, in 1885-written by a man whom his worst enemy could not accuse of trying to advertise British Columbia, or striving to induce immigration by sanguine representations of the benefits to be obtained by the incomers, and by a man, moreover, who knows and has known British Columbia since the very early days as few others know or have known it. That, at least, is his reputation in the island which is his home. When Sir Matthew wrote the above, British Columbians were beginning to tremble at the competition of cheap Chinese labour. In the recent Budget speech, the Finance Minister of British Columbia said: 
' Three years ago there were 16,000 Chinamen in British Columbia, now there are only 8,000 ; but ' 10,000 whites were added to the population in 1887.'

The effect of the last three years upon the rate of wages in British Columbia has not been, as far as I can see, very material. There is an increasimg white population, and an increasing demand for certain kinds of labour. There are fewer Chinamen, and those who are there get white men's wages, and thoroughly earn them. But of them I should like to say a word later on. Farm-labourers' wages appear still to be about two dollars a day, or eight shillings. Even a man or boy to assist in a 'camp outfit' as cook or general help wants two dollars and his food. As miners, farm-labourers, carpenters, plumbers, or experts in any kind of manual labour, Englishmen will find lots of work to do, and good pay for doing it. As clerks and office-seekers they will find that they are not wanted.

Travelling as I did from one end of Canada to the other, I picked up some information as to work and wages all along my route. Here are some of the facts collected:

At Halifax, a town which in November should bring his home very vividly before the emigrant from London, as being dirtier, more foggy, and 
therefore more home-like than any other town out of the United Kingdom, the average wage for a labourer without board is five shillings a day. This is for unskilled labour. A gardener without board gets six shillings a day, and the plainest of plain cooks twenty-two pounds a year, and an unlimited choice of mistresses.

In Ottawa I interviewed a gardener, whose wages, he told me, were thirty-six shillings a week, whilst his work was of the very simplest description. His five-roomed cottage cost him seven shillings a week, and he was able to buy the best beef-steak at sixpence a pound. But the Ottawa gardener deprecated the idea of living in another man's house. Out of his savings he had bought a small plot of land in the town, and in his spare time had built upon it, principally with his own hands, a home for himself and his wife, whose labours as a laundress added another thirty shillings a month to the family income.

In Winnipeg, the most go-ahead of all Canadian towns, with a climate pleasant and bracing, in spite of the extremes registered by the thermometer, both in summer and winter, farmlabourers' wages are a trifle higher than in Halifax. Miners' wages are a little higher than farm-labourers', and any kind of a cook is worth at least twenty-five pounds a year and her board. 
In Olympia, a new town of the States, upon Puget Sound, a large employer of labour told me that he paid his farm-labourers thirty-five dollars a month without board, and that labourers experienced no difficulty in finding work at that rate of wages all the year round. In Olympia a cottage may be rented at one pound a month, and a water-rate of eight shillings a month, all other rates and taxes being paid by the landlord, while the people who have no property, though they pay no taxes, have the advantage of firstrate free schools.

As to female labour, generally speaking, it is in great demand and highly paid throughout Canada. Even in England, I have cause to know that competent cooks and respectable parlour-maids are more often sought than found. What the daughters of the working-classes are doing when their fathers and brothers say that they are starving for want of work it is difficult to conceive. It cannot be very hard for a woman to learn to cook or wait at table, and yet look at the number of advertisements for women who can do these things in every daily paper.

The lucky Victorians have found a substitute for cook and parlour-maid in the versatile Chinaman. They grumble at him, of course; but what they would do without him, no man can 
guess. Docile, clean, ready to work, and able to do anything that a woman can, the universal employment of them as domestic servants, at a high rate of wages, proves the esteem in which they are held. As cooks, I can testify of my own knowledge to their excellency. I have had experience (and pretty frequent experience) of three different Chinese cooks in private houses during my wanderings out West. I can honestly say that I never had a cook in England fit to hold a candle to any one of the three. But high rates of wages will not greatly help the workman if the price of the necessaries of life is so high as to swallow up all he earns. In Victoria food is undeniably cheap; that is to say, bread and meat, the absolute necessaries of life, with fish and fruit, are cheap; but groceries, coal, and clothing are dear. I think my wife computed that living in the best way in which you can live in Victoria would cost about as much as such living would do in England. Thanks to a friend before referred to, I am able to give some accurate figures regarding the cost of labourers' food in the neighbourhood of Olympia, and I fancy that little difference would be found to exist between the cost of living there and in Vancouver Island. A farm-labourer's board is calculated at 35 cents per diem (say 1s. $5 \frac{1}{2} \mathrm{~d}$.), while in the lumberers' 
camps the men can be boarded for a little less, $33 \frac{1}{2}$ cents a day being the allowance for food per man, though these men, doing hard work in the keen open air, have giants' appetites to satisfy and giants' muscles to maintain. Of course the food is plain ; boiled beef sometimes, bacon more often, beans, brown sugar, bread, and maple syrup-these are the principal items in the lumberer's bill of fare; but the quality of this simple food must be good, and the quantity unstinted, or there will soon be grumbling in the shanties.

Apropos of lumbering, it is fair to remind emigrants, attracted by this most fascinating of all forms of physical labour, that the lumberer is not employed all the year round, so that a man taking to the axe for a livelihood must be prepared to work at some other employment during those months in which the gangs are out of the timber limits.

One more word, and I have done with the emigrant labourer. The Commission which sat on the Chinese Question in British Columbia, brought to light incidentally a few facts of interest to our unemployed. There were unemployed in England before the date of that Commission, just as there are now. I believe there is work in Canada, and handsome wages for English muscle and English energy, just as there was 
then. What our unemployed did then, let us hope their successors will not do now. Then they allowed the little yellow Chinamen to get the work and take the money away with them; they let Chinamen build the railways, reclaim the marshes, till the fields and vineyards of a land which should have been the English labourers' inheritance. On the Central Pacific Railway alone four-fifths of the labour was done by Chinese. On the Southern Pacific Railway, again Chinese took the work which Englishmen should have done, and this through no want of patriotism on the part of the employers of labour, or any niggardliness in the matter of pay. On the contrary, the builders of these lines were prejudiced strongly in favour of white labour, and had a strong disinclination to employ Chinamen. Over and over again they advertised for white labourers, but could not get them, and those they obtained allowed themselves, through drink and want of steadiness, to be beaten by the Chinese; for no one who knows them can believe that the Chinaman has yet been born who could beat a Cornish miner at his own work. And yet the gang of Chinamen beat the gang of Cornish miners in the rock-cutting in the summit tunnel of the Central Pacific Railway line, according to the evidence given by Mr. Crocker in 
1885. The wages earned by white navvies on these two works were about 45 dollars a month and board. There is lots of work still to be had in British Columbia for strong and willing men, though much of the land has already been reclaimed, and most of the great lines have been built.

There is another class to which British Columbia holds out great inducements-the men, I mean, of small capital or limited incomes, the ruined landlords and soldiers, of whom England considers that she has no longer any need. To these latter British Columbia is specially kind. I dare say I am insufficiently informed, but I know of no other country to-day in which retired officers, formerly in her Majesty's Service, are offered free grants of land as they are in British Columbia.

To a subaltern of seven years' service, British Columbia offers 200 acres of land as a free grant; to field officers of twenty-five years' service, she offers 600 acres. As a home the world cannot offer anything better than Vancouver's Island to my mind, save for those luxuries and advantages of society, amusement, and education, which in the nature of things can only be obtained in crowded centres. As to the society, it is made up largely in Victoria of the same sort of people 
whom you would meet in English country towns, with the addition of a large body of naval officers on duty at Esquimalt, and a resident bar.

As to education, there is certainly some room for improvement; but the English gentleman who elects to reside at Victoria should be able to save enough money to send his boy home to one of our English public schools when the lad is old enough for it; for if you cannot make money as rapidly in Vancouver as you can in the States-a point which I do not concede, though I do not feel prepared to argue it-at least you can live happily on a small income, and save more than you would make elsewhere. There are no very rich people on the island, no very big entertainments, no rivalry between the squire and the plutocrat, the parson and the squire. If tennis and music, a few dances every year, gardening, and boating, with a lovely home amongst English neighbours, will satisfy a lady, she can be happy at Victoria; if not, she had better stay at home. If splendid fishing, poor rough-shooting, big-game-shooting, within two or three days of home, will satisfy her husband, and if they can no longer live as they have been accustomed to do in the old country, and make both ends meet, whilst putting by something for the children, let them take tickets by the Allan 
Line to Quebec (£10 10s. each for saloon accommodation), and thence to Victoria, Vancouver's Island, by the Canadian Pacific, the cost of this part of the journey being at present only $£ 15$ 8s. 3d. each for first-class passengers. To this fare, however, must be added the cost of living on the train, which you may reckon at 75 cents a meal, the meals being served in the dining-saloon. Two meals a day are about as much as the ordinary digestion can compass, though a luncheon-basket to console you at midday, or whenever the dining-car is not available, is a very necessary adjunct to a perfect travelling equipment. Of course these rules as to food do not apply to anti-tobacconists or teetotalers. I presume a double allowance of the food-supply should meet their requirements. There is one other expense for which allowance must be made, i.e., the sleeping-compartment, without which, to my mind, the trans-continental journey would be, for a lady, intolerable. The cost of a double berth is about $12 \mathrm{~s}$. a day, and for this travellers get not only a comfortable couch at night, but a couch or arm-chair by the window during the day.

If I have forgotten anything, gentle reader, which you or your husband want to know, forgive me, and accept this advice as my amende 
honorable. The Canadian Agency is close to your favourite haunt (of course I mean the Army and Navy Stores), and should you invade the library of that establishment, you will find all the information you can possibly require about British Columbia, and, unless my experience has been unique, more courtesy and kindness than in any public office in London.

Your obedient servant,

C. P. W.

THE END. 



\section{RICHARD BENTLEY AND SON'S LIST OF \\ FORTHCOMING WORKS.}

THE LIFE OF RICHARD, FIRST BARON WESTBURY, Lord High Chancellor of England. By Thomas Arthur Nash, Barrister-at-Law. In 2 vols., demy 8vo., with two portraits, 305 .

FURTHER REMINISCENCES, forming the Third Volume of 'My Life and Reminiscences.' By W. P. Frith, R.A. In demy $8 v o$., with portrait, $15 \mathrm{~s}$.

LIFE AND LETTERS OF MARY WOLLSTONECRAFT SHELLEY. From Family Papers not hitherto published, in the possession of Sir Percy Shelley. By Mrs. Julian Marshall. In 2 vols., crown 8 vo., with portrait, $24 \mathrm{~s}$.

JOHN FRANCIS AND THE 'ATHENAUM.' A Literary Chronicle of Half a Century. By John C. Francis. In 2 vols., crown 8 vo., with two portraits, $24 \mathrm{~s}$.

THE AUTOBIOGRAPHY OF THE ELECTRESS SOPHIA OF HANOVER. From the German, by Mrs. Leighton. In 2 vols., crown 8vo., 2Is.

THE HORSE: and How to Breed and Rear Him. The Thoroughbred - Hunter-Carriage-horse- $\mathrm{Cob}-$ Farmhorse-Dray-horse-Pony, etc. By William Day, author of 'The Race-horse in Training,' etc. In demy Svo.

NAPOLEON AT SAINT HELENA. By Barry E. O'Meara, Body-Surgeon to the Emperor. A New Edition, with copious notes and other additions, and embellished by several coloured plates, portraits, and woodcuts. In 2 vols., demy 8 vo., 305.

PROFESSOR MOMMSEN'S HISTORY OF ROME, from the Earliest Times to the Period of its Decline. An abridgment for the use of Colleges and Schools. By C. Bryans and F. J. R. Hendy. In crown 8vo., 7 s. 6 d.

OUR RARER BIRDS. By Charles Dixon, author of 'Rural Bird Life.' With numerous illustrations by Charles Whymper. In demy 8 vo., ros. $6 \mathrm{~d}$. 
A SPORTSMAN'S EDEN. A Season's Shooting in Upper Canada, British Columbia, and Vancouver. By Clive Phillipps-Wolley, author of 'Sport in the Crimea and Caucasus,' etc. In demy 8vo., Ios. $6 \mathrm{~d}$.

THE HISTORY OF JERUSALEM : the City of Herod and Saladin. By Walter Besant, M.A., and E. H. Palmer, M.A., late Professor of Arabic, Cambridge. A New and Revised Edition. In large crown 8vo., with map and woodcuts, $7 \mathrm{~s} .6 \mathrm{~d}$.

ROOTS: A Plea for Tolerance. A New Edition. In one volume.

LETTERS FROM MAJORCA. By Charles W. Wood, F.R.G.S., author of 'Through Holland.' In demy 8 vo., with nearly one hundred illustrations, I6s.

FRANCIS THE FIRST AND HIS TIMES. From the French of Madame C. Coignet, by Fanny Twemlow. In demy 8vo., with portrait.

THE WANDERINGS OF A GLOBE TROTTER. By the Hon. Lewis Wingfield, author of 'Lady Grizel.' In 2 vols., crown 8vo., 21s.

THE DOMINION OF MAN OVER ANIMALS. By the Rev. J. G. Wood, author of 'Common Objects of the Sea-shore,' etc. In demy 8vo., with numerous illustrations.

RURAL ITALY. An Agricultural Survey of the Present Condition of the Italian Peninsula and Sicily. By W. Nelthorpe Beauclerk, late of Her Britannic Majesty's Embassy at Rome. In demy 8vo., gs.

A DRIVE THROUGH THE EASTERN COUNTIES. By James John Hissey, author of 'On the Box-seat,' etc. In demy 8 vo., with map and numerous illustrations from sketches by the author.

OUR IRON ROADS. Their History, Construction, and Administration. By Frederick S. Williams, author of 'The Rise and Progress of the Midland Railway.' A New Edition. In demy 8vo., 8s. 6d.

THE MIDLAND RAILWAY: Its Rise and Progress. By Frederick S. Williams, author of ' Our Iron Roads,' etc. A New Edition. In crown 8vo., with numerous illustrations, $6 \mathrm{~s}$.

LONDON : RICHARD BENTLEY AND SON, Bublishers in Ordinaxy to ?fex atajesty the Queen. 




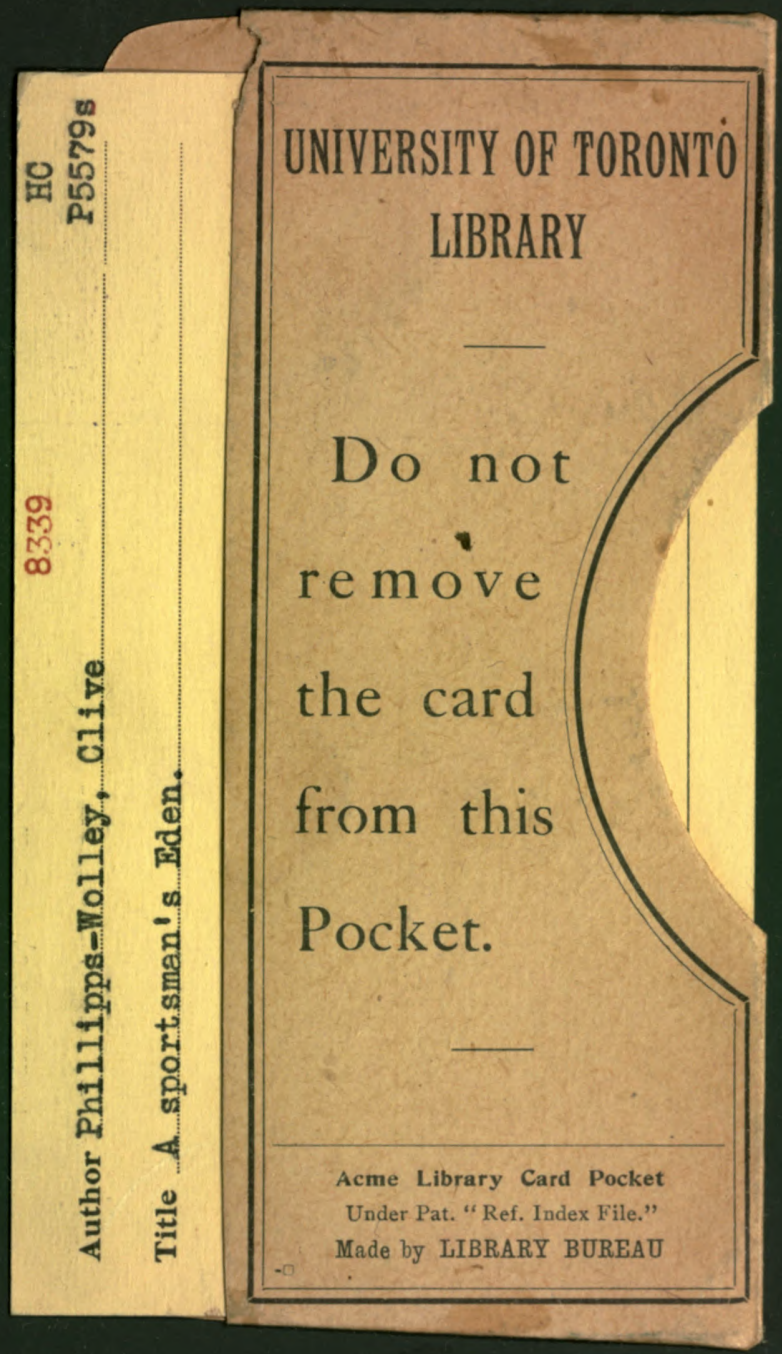


